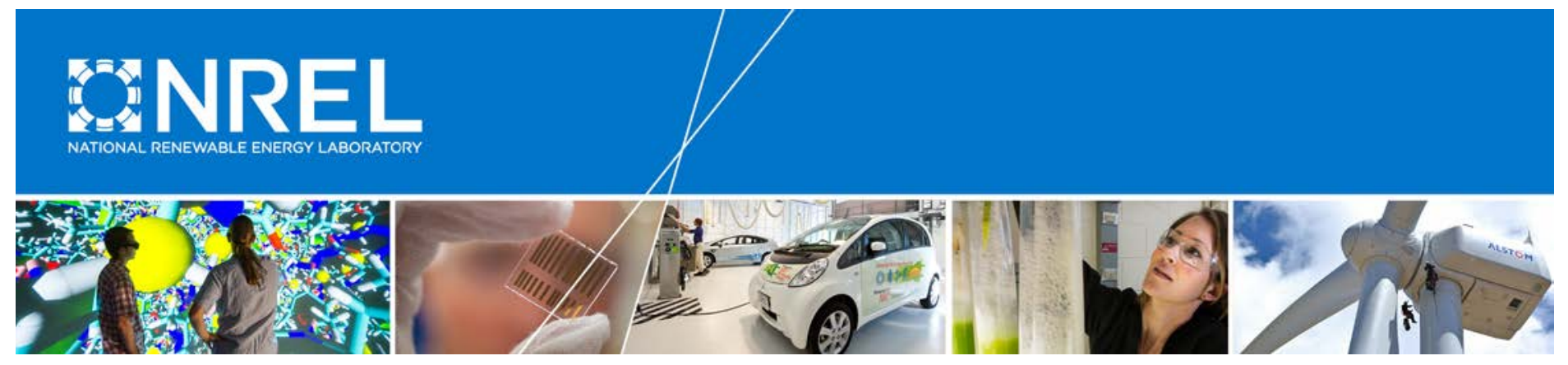

\title{
Status and Trends in the U.S. Voluntary Green Power Market (2016 Data)
}

Eric O'Shaughnessy, Jenny Heeter, Jeff Cook, and Christina Volpi National Renewable Energy Laboratory

NREL is a national laboratory of the U.S. Department of Energy Office of Energy Efficiency \& Renewable Energy Operated by the Alliance for Sustainable Energy, LLC

This report is available at no cost from the National Renewable Energy Laboratory (NREL) at www.nrel.gov/publications.

Technical Report

NREL/TP-6A20-70174

October 2017

Contract No. DE-AC36-08G028308 


\section{Status and Trends in the U.S. Voluntary Green Power Market (2016 Data)}

\author{
Eric O'Shaughnessy, Jenny Heeter, \\ Jeff Cook, and Christina Volpi \\ National Renewable Energy Laboratory
}

Prepared under Task No. OOSP.10291.05.02.04
NREL is a national laboratory of the U.S. Department of Energy Office of Energy Efficiency \& Renewable Energy Operated by the Alliance for Sustainable Energy, LLC

This report is available at no cost from the National Renewable Energy Laboratory (NREL) at www.nrel.gov/publications.

\section{Technical Report}

NREL/TP-6A20-70174

October 2017

Contract No. DE-AC36-08GO28308
National Renewable Energy Laboratory 15013 Denver West Parkway 303-275-3000 • www.nrel.gov 


\section{NOTICE}

This report was prepared as an account of work sponsored by an agency of the United States government. Neither the United States government nor any agency thereof, nor any of their employees, makes any warranty, express or implied, or assumes any legal liability or responsibility for the accuracy, completeness, or usefulness of any information, apparatus, product, or process disclosed, or represents that its use would not infringe privately owned rights. Reference herein to any specific commercial product, process, or service by trade name, trademark, manufacturer, or otherwise does not necessarily constitute or imply its endorsement, recommendation, or favoring by the United States government or any agency thereof. The views and opinions of authors expressed herein do not necessarily state or reflect those of the United States government or any agency thereof.

This report is available at no cost from the National Renewable Energy Laboratory (NREL) at www.nrel.gov/publications.

Available electronically at SciTech Connect http:/www.osti.gov/scitech

Available for a processing fee to U.S. Department of Energy and its contractors, in paper, from:

U.S. Department of Energy

Office of Scientific and Technical Information

P.O. Box 62

Oak Ridge, TN 37831-0062

OSTI http://www.osti.gov

Phone: 865.576.8401

Fax: 865.576.5728

Email: reports@osti.gov

Available for sale to the public, in paper, from:

U.S. Department of Commerce

National Technical Information Service

5301 Shawnee Road

Alexandria, VA 22312

NTIS http://www.ntis.gov

Phone: 800.553 .6847 or 703.605 .6000

Fax: 703.605.6900

Email: orders@ntis.gov 


\section{Acknowledgments}

This work was funded by the U.S. Department of Energy's (DOE's) Office of Energy Efficiency and Renewable Energy. The authors thank the DOE Strategic Programs Office and the DOE Solar Energy Technologies Office for their support of this work. For their thoughtful review of the document, the authors thank Anthony Amato (Eastern Research Group), Priya Barua (World Resources Institute), Lori Bird (NREL), Celina Bonugli (World Resources Institute), Stephen Capanna (DOE), James Critchfield (U.S. Environmental Protection Agency), Ed Holt (Ed Holt \& Associates), Tom Matzzie (CleanChoice Energy), and Kara Podkaminer (DOE), as well as Mike Meshek of NREL for editorial support. Finally, the authors thank the many green power marketers and utility contacts who provided the information summarized in this report.

This work was supported by the U.S. Department of Energy under Contract No. DE-AC3608GO28308 with the National Renewable Energy Laboratory. 


$\begin{array}{ll}\text { List of Acronyms } \\ \text { CAISO } & \text { California Independent System Operator } \\ \text { CCA } & \text { community choice aggregation } \\ \text { ERCOT } & \text { Electric Reliability Council of Texas } \\ \text { ISONE } & \text { Independent System Operator of New England } \\ \text { kWh } & \text { kilowatt-hour } \\ \text { MISO } & \text { Midwest Independent System Operator } \\ \text { MW } & \text { megawatt } \\ \text { MWh } & \text { megawatt-hour } \\ \text { NREL } & \text { National Renewable Energy Laboratory } \\ \text { PG\&E } & \text { Pacific Gas and Electric } \\ \text { PJM } & \text { Pennsylvania, Jersey, Maryland Power Pool } \\ \text { PPA } & \text { power purchase agreement } \\ \text { PV } & \text { photovoltaic } \\ \text { RE } & \text { renewable energy } \\ \text { REC } & \text { renewable energy certificate } \\ \text { RPS } & \text { renewable portfolio standard } \\ \text { SPP } & \text { Southwest Power Pool } \\ \text { SREC } & \text { solar renewable energy certificate } \\ \text { TVA } & \text { Tennessee Valley Authority }\end{array}$




\section{Executive Summary}

Green power - for the purposes of this report - refers to renewable electricity voluntarily purchased by retail electricity customers. It is substantiated through renewable energy certificates (RECs). The voluntary green power market encompasses seven green power procurement mechanisms: utility green pricing programs, utility renewable contracts, unbundled RECs, competitive suppliers, community choice aggregations (CCAs), power purchase agreements (PPAs), and community solar.

About 6.3 million customers procured about 95 million megawatt-hours (MWh) of green power in 2016 (Table ES-1), which represents a 45\% increase in the number of customers and a 19\% increase in the amount sales from 2015. The voluntary green power market now accounts for about $28 \%$ of all U.S. renewable energy sales, excluding large hydropower.

Table ES-1. Voluntary Green Power Participation and Sales in 2016

\begin{tabular}{lrr}
\hline Green Power Option & Sales (MWh) & Participants \\
\hline Utility green pricing & $8,012,000$ & 816,000 \\
Utility renewable contracts & $2,930,000$ & 9 \\
Competitive suppliers & $16,047,000$ & $2,011,000$ \\
Unbundled RECs & $51,800,000$ & 108,000 \\
CCAs & $8,738,000$ & $3,336,000$ \\
PPAs & $7,891,000$ & 210 \\
Community solar & 258,000 & 23,000 \\
\hline Total $^{\text {a }}$ & $95,450,000$ & $6,276,000$ \\
\hline
\end{tabular}

${ }^{a}$ Total excludes community solar except for PG\&E's Solar Choice program because most customers do not retain RECs.

Sales and participation increased across all green power mechanisms from 2015 to 2016. Unbundled RECs account for more than half of the green power market in terms of sales. Unbundled REC sales have continued to increase in recent years as corporations and other large non-residential customers make large green power purchases to meet internal renewable energy or sustainability goals. CCAs now account for more than half of green power customers. The significant increase in green power participation from 2015 to 2016 is primarily attributable to the enrollment of large numbers of residential customers into new and growing CCAs in California, Illinois, Massachusetts, and New York.

For the first time in this annual series, this report includes a state-level analysis of the geography of voluntary green power sales and customers. Demand for green power is ubiquitous in the United States. Where green power is available, green power customers procure green power through locally available options such as utility green pricing programs, competitive suppliers, and CCAs. Customers also procure green power through unbundled RECs or PPAs, especially in states and utility service territories without local green power options. The geographic expansion of green power will likely continue as green power costs decline and providers continue to develop innovative green power products. 


\section{Table of Contents}

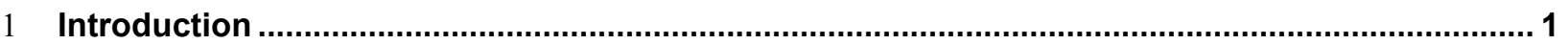

2 Summary of Voluntary Green Power Participation and Sales .................................................. 4

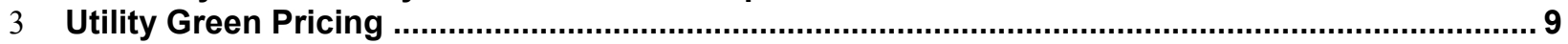

3.1 Status of Utility Green Pricing Programs ........................................................................... 9

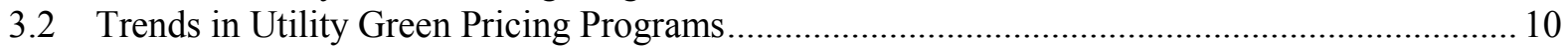

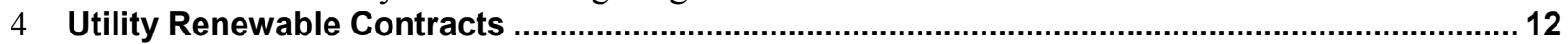

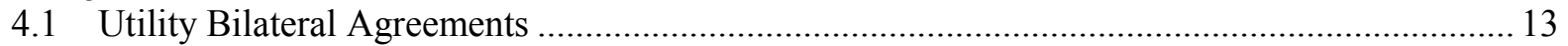

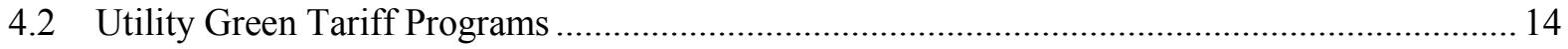

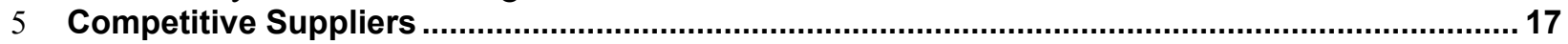

5.1 Status of Competitive Supplier Green Power........................................................................... 17

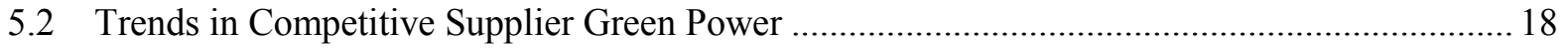

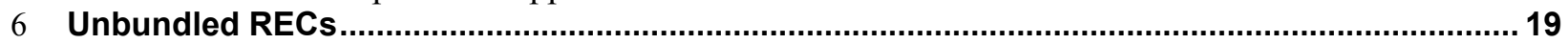

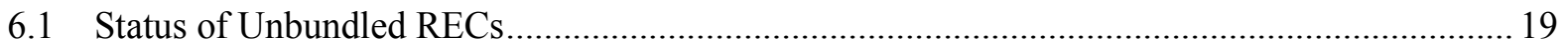

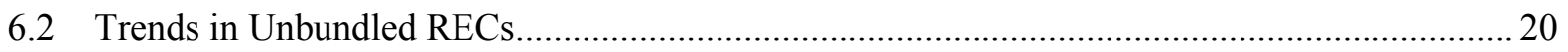

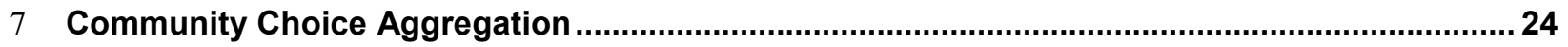

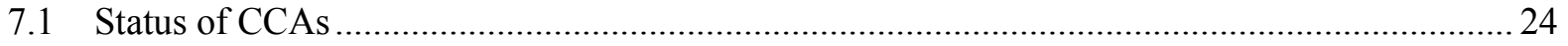

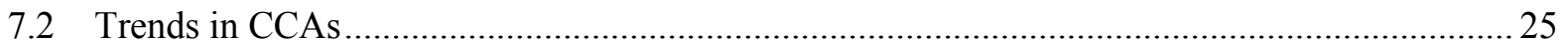

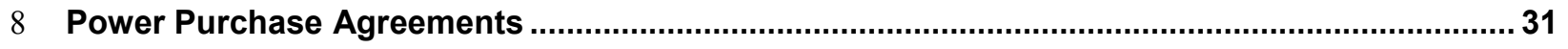

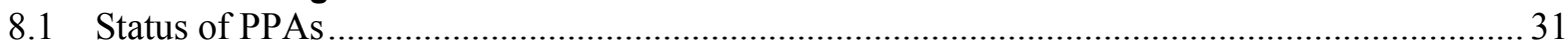

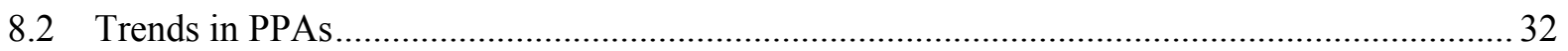

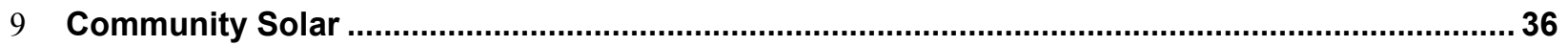

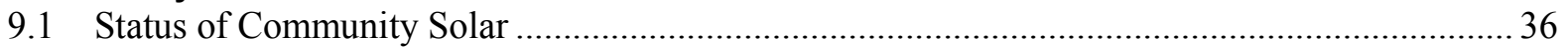

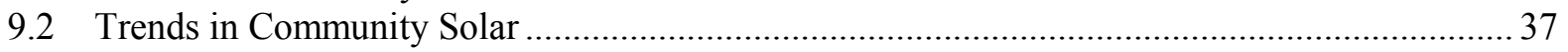

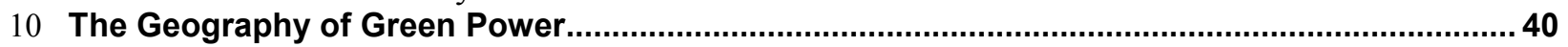

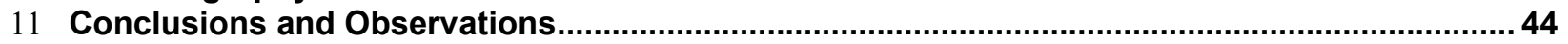

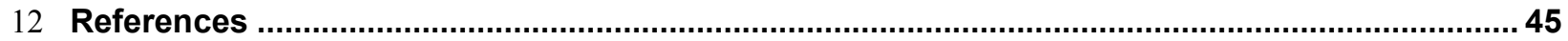

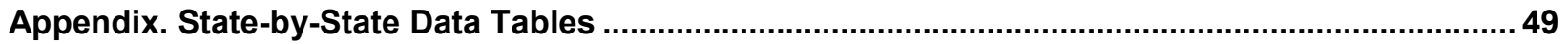




\section{List of Figures}

Figure 1. Percentage changes (2015-2016) in green power market participation and sales...................... 4

Figure 2. Green power sales by mechanism (2010-2016) .................................................................. 5

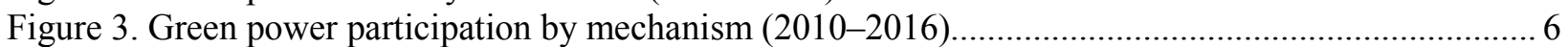

Figure 4. Shares of green power sales (left pane) and customers (right pane) over time by mechanism ..... 7

Figure 5. Renewable energy sales in voluntary, compliance, and other markets from 2010 to $2016 \ldots \ldots \ldots . . .8$

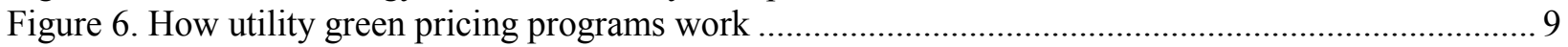

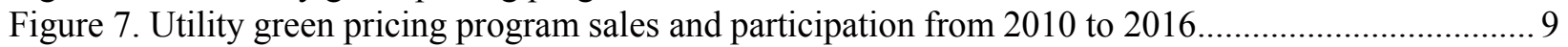

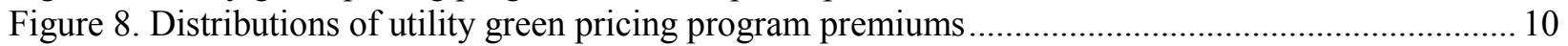

Figure 9. Utility green pricing program renewable energy resources.................................................. 10

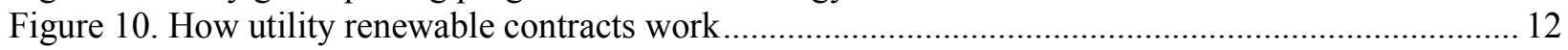

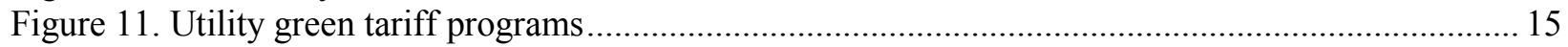

Figure 12. Cumulative utility renewable contract capacity by state (MW) ........................................ 16

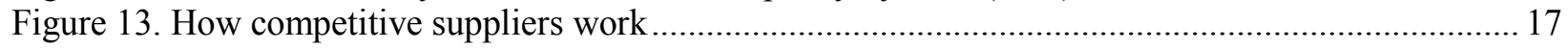

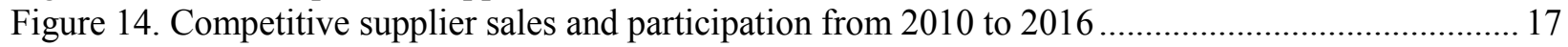

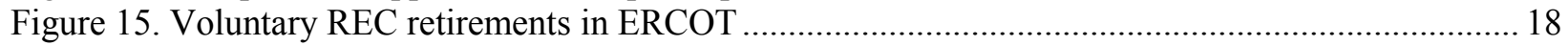

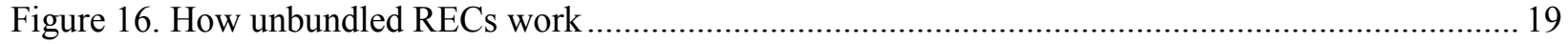

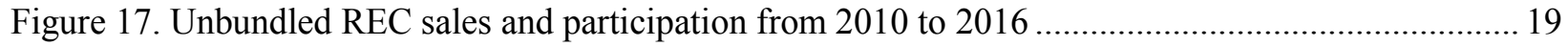

Figure 18. Large customer renewable energy commitments and purchasers ......................................... 21

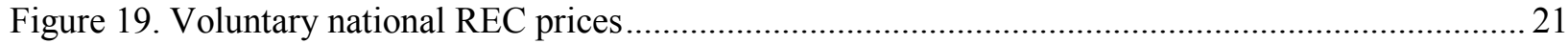

Figure 20. Compliance REC prices (excluding SRECs), January 2010 - August 2017 …...................... 22

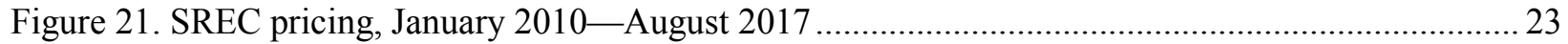

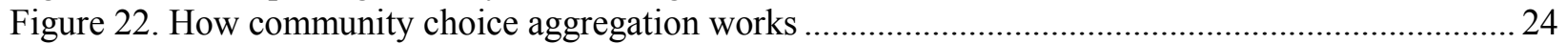

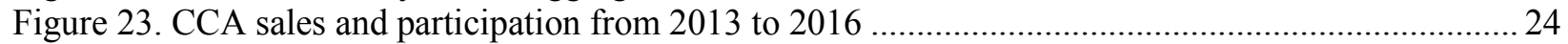

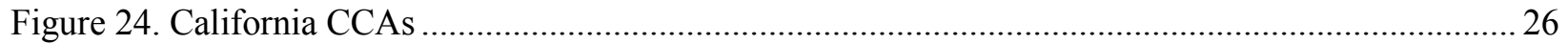

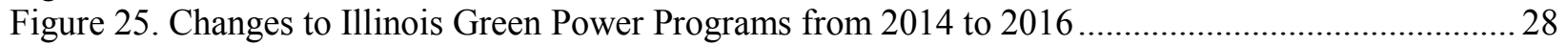

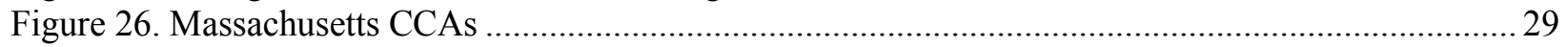

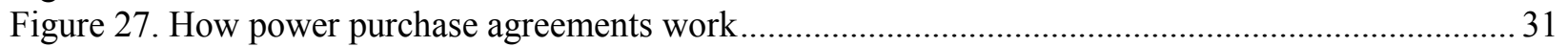

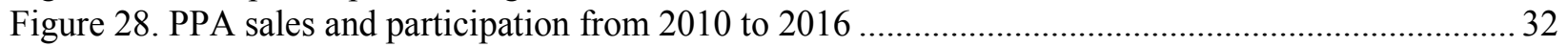

Figure 29. Project status of corporate PPAs, with and without RECs, through July 2017 ....................... 32

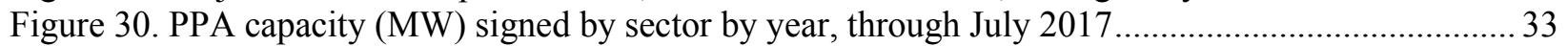

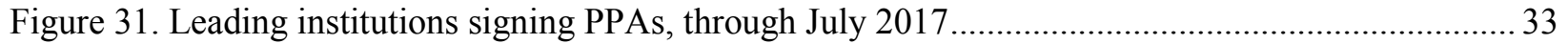

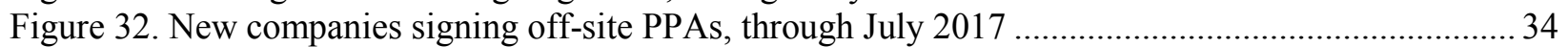

Figure 33. Share of signed PPAs by region (based on location of generator) ….................................... 35

Figure 34. Map of regional transmission organizations and independent system operators...................... 35

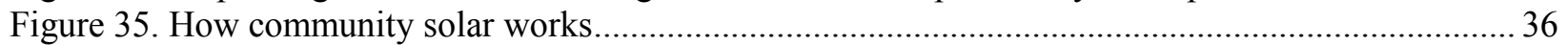

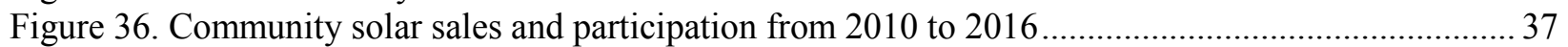

Figure 37. Active community solar projects and states with community solar policies .......................... 38

Figure 38. Active and pending community solar projects in Minnesota and Wisconsin........................... 39

Figure 39. Primary form of green power demand (number of customers) by state ................................. 40

Figure 40. Utility green pricing program \# of customers (left pane) and green power generation source

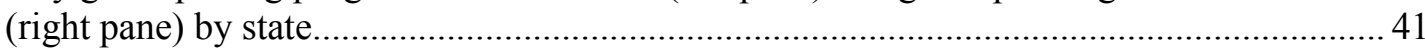

Figure 41. Unbundled RECs: Number of customers (left pane) and green power generation source

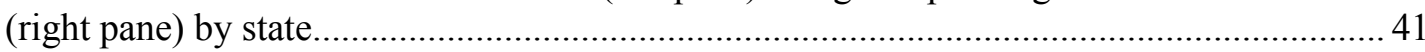

Figure 42. Geographic sample of residential and small commercial green power customers ................... 42

Figure 43. Number of PPAs (left pane) and generation (right pane) by state........................................ 42

Figure 44. The geography of green power customer demand: number of green power customers by state 43

Figure 45. The geography of green power supply: green power generation (million MWh) by state........ 43 


\section{List of Tables}

Table ES-1. Voluntary Green Power Participation and Sales in 2016 ...................................................

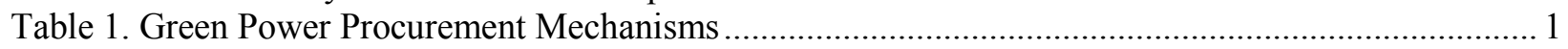

Table 2. Methodologies, Resources, and Data Limitations ................................................................. 2

Table 3. Voluntary Green Power Participation and Sales in 2016 ...................................................... 4

Table 4. Estimated Green Power Sales (millions of MWh), 2010-2016 ................................................ 5

Table 5. Estimated Green Power Participation ( $\times 1,000$ customers), 2010-2016 ..................................... 6

Table 6. Contract Length by Type of Utility Green Power Procurement (MWh), 2015 ......................... 11

Table 7. Bilateral Agreements for Renewable Energy by State, Company, and Utility ........................... 13

Table 8. CCA Green Power Sales and Participation by State in 2016 ...................................................25

Table 9. Select CCA Residential Rate Comparison with Certain Utility Rates in California ................... 27

Table A-1. Green Power Customers by State .......................................................................................... 49

Table A-2. Estimated Green Power Production (MWh) by State of Origin ............................................ 52 


\section{Introduction}

Green power-for the purposes of this report - refers to renewable electricity voluntarily purchased by retail electricity customers. It is substantiated through renewable energy certificates (RECs). This report summarizes data on the various ways in which voluntary purchasersincluding residential, commercial, and institutional customers - purchase renewable energy, often to meet their own sustainability goals.

Electricity customers have several mechanisms through which to buy green power (Table 1). This report also summarizes the status and trends of renewable energy purchases through these procurement mechanisms.

Table 1. Green Power Procurement Mechanisms

\begin{tabular}{|c|c|c|}
\hline Mechanism & Report Section & Description \\
\hline Utility green pricing & 3 & $\begin{array}{l}\text { Utility customers procure green power on a } \\
\text { month-to-month basis through an added fee } \\
\text { on their utility bill }\end{array}$ \\
\hline Utility renewable contracts & 4 & $\begin{array}{l}\text { Utility customers procure green power from } \\
\text { their utility through a special tariff or bilateral } \\
\text { contract, typically on a long-term basis } \\
\text { sourced from a new renewable energy } \\
\text { generator }\end{array}$ \\
\hline Unbundled RECs & 5 & $\begin{array}{l}\text { Customers buy RECs separated or } \\
\text { "unbundled" from the underlying electricity }\end{array}$ \\
\hline Competitive suppliers & 6 & $\begin{array}{l}\text { Customers in competitive electricity markets } \\
\text { may select a green power option from an } \\
\text { alternative retail electricity supplier }\end{array}$ \\
\hline $\begin{array}{l}\text { Community choice } \\
\text { aggregations (CCA) }\end{array}$ & 7 & $\begin{array}{l}\text { Communities aggregate their loads to } \\
\text { collectively procure green power as a bulk } \\
\text { purchaser through an alternative electricity } \\
\text { supplier }\end{array}$ \\
\hline $\begin{array}{l}\text { Power purchase } \\
\text { agreements }\end{array}$ & 8 & $\begin{array}{l}\text { Customers procure green power through a } \\
\text { long-term contract with an off-site renewable } \\
\text { energy project }\end{array}$ \\
\hline Community solar & 9 & $\begin{array}{l}\text { Customers buy a subscription in a shared } \\
\text { solar project and accrue green power in } \\
\text { proportion to their subscription }\end{array}$ \\
\hline
\end{tabular}

This report focuses on renewable energy procured voluntarily; it does not include purchases made to comply with renewable portfolio standard (RPS) obligations. For example, competitive suppliers and community choice aggregations (CCAs) are subject to RPS compliance in states with RPS, and therefore a fraction of their sales are used to meet their compliance obligations. 
All sales estimates (megawatt-hours) for competitive suppliers and CCAs factor out the portion of renewable energy sales used toward RPS compliance.

Further, this report does not include data on green power consumption where RECs are not delivered to and retained by the customer. For example, if the RECs from a community solar project are used by the utility to meet RPS compliance, the project is not counted as voluntary purchasing. Similarly, for on-site photovoltaic (PV) systems, often the system owner grants to the RECs to the utility in exchange for a subsidy and the utility counts the system toward RPS obligations. In these cases, the system is also not counted in voluntary market totals. Lastly, this report does not include data from on-site systems where RECs are not procured through one of the mechanisms in Table 1. Data from the U.S. EPA's Green Power Partnership suggest that onsite green power consumption may amount to about $4 \%$ of the green power market summarized in this report, or about four million MWh annually. Additional on-site green power, not accounted for in this report, is occurring through residential installations and organizations that are not part of the Green Power Partnership.

\section{Data Sources and Limitations}

Green power market data are based on figures provided to the National Renewable Energy Laboratory (NREL) by utilities and independent renewable energy marketers and publicly available data (Table 2). The data on voluntary market trends presented in this report build on data presented in Status and Trends in the U.S. Voluntary Green Power Market (2015 Data) (O’Shaughnessy, Liu, and Heeter 2016).

Table 2. Methodologies, Resources, and Data Limitations

\begin{tabular}{ll}
\hline Mechanism & Methodology, Resources, and Limitations \\
\hline Utility green pricing & $\begin{array}{l}\text { National estimate extrapolated from data collected from 42 utility } \\
\text { programs. NREL estimates that the data sample represents over } \\
75 \% \text { of utility green pricing sales. }\end{array}$ \\
\hline $\begin{array}{l}\text { Utility renewable } \\
\text { contracts }\end{array}$ & $\begin{array}{l}\text { Estimates based on data from WRI (2017) and Heeter, Cook, and } \\
\text { Bird (2017) }\end{array}$ \\
\hline Unbundled RECs & $\begin{array}{l}\text { National estimate extrapolated from data provided by the Green-e } \\
\text { national certification program (Leschke 2017) }\end{array}$ \\
\hline Competitive suppliers & $\begin{array}{l}\text { National estimate extrapolated from data collected from six suppliers } \\
\text { and publicly available data from the Electric Reliability Council of } \\
\text { Texas (ERCOT); data limitations associated with the small sample } \\
\text { size for competitive suppliers limit the interpretation of status and } \\
\text { trends in this green power mechanism. }\end{array}$ \\
\hline $\begin{array}{l}\text { Community choice } \\
\text { aggregations }\end{array}$ & $\begin{array}{l}\text { Estimates for California, Massachusetts, New York, and Ohio based } \\
\text { on data collected from CCAs; estimates for Illinois based on Dynegy } \\
\text { (2017) and ICC (2017) }\end{array}$ \\
\hline $\begin{array}{l}\text { Power purchase } \\
\text { agreements }\end{array}$ & \begin{tabular}{l} 
Based on data obtained from BNEF (2017) \\
\hline
\end{tabular}
\end{tabular}




\begin{tabular}{ll}
\hline Mechanism & Methodology, Resources, and Limitations \\
\hline & Based on data on operational community solar projects compiled from \\
various sources, state-level solar capacity factors, and assumed & average subscription sizes per customer; REC treatment is unknown \\
for the majority of projects. Community solar sales and participation \\
figures are therefore excluded from green power market totals, except \\
for sales and participation from PG\&E's Solar Choice program (where \\
by design customers retain RECs).
\end{tabular}

\section{Structure of this Report}

Section 2 provides an overall summary of the status of the green power market with national totals of sales (MWh) and participation (number of customers). Sections 3-9 summarize the status and trends for each of the green power procurement mechanisms. Section 10 summarizes the geography of green power markets. Section 11 provides conclusions. 


\section{Summary of Voluntary Green Power Participation and Sales}

About 6.3 million U.S. electricity customers purchased about 95 million MWh of green power in 2016 (Table 3).

Table 3. Voluntary Green Power Participation and Sales in 2016

\begin{tabular}{lrr}
\hline Green Power Option & Sales (MWh) & Participants \\
\hline Utility green pricing & $8,012,000$ & 816,000 \\
Utility renewable contracts & $2,930,000$ & 9 \\
Competitive suppliers & $16,047,000$ & $2,011,000$ \\
Unbundled RECs & $51,800,000$ & 108,000 \\
CCAs & $8,738,000$ & $3,336,000$ \\
PPAs & $7,891,000$ & 210 \\
Community solar & 258,000 & 23,000 \\
\hline Total $^{\text {a }}$ & $95,450,000$ & $6,276,000$ \\
\hline
\end{tabular}

a The total excludes community solar except for PG\&E's Solar Choice program because most community solar customers do not retain RECs.

Figure 1 illustrates the percentage changes in green power participation and sales from 2015 to 2016. Increasing corporate interest in green power and low REC prices are contributors to growth in unbundled RECs (Section 5). New CCA programs and program expansions in California, Massachusetts, and New York have fueled the growth of CCAs (Section 7). Community solar continues to grow rapidly as new projects are developed (Section 9).

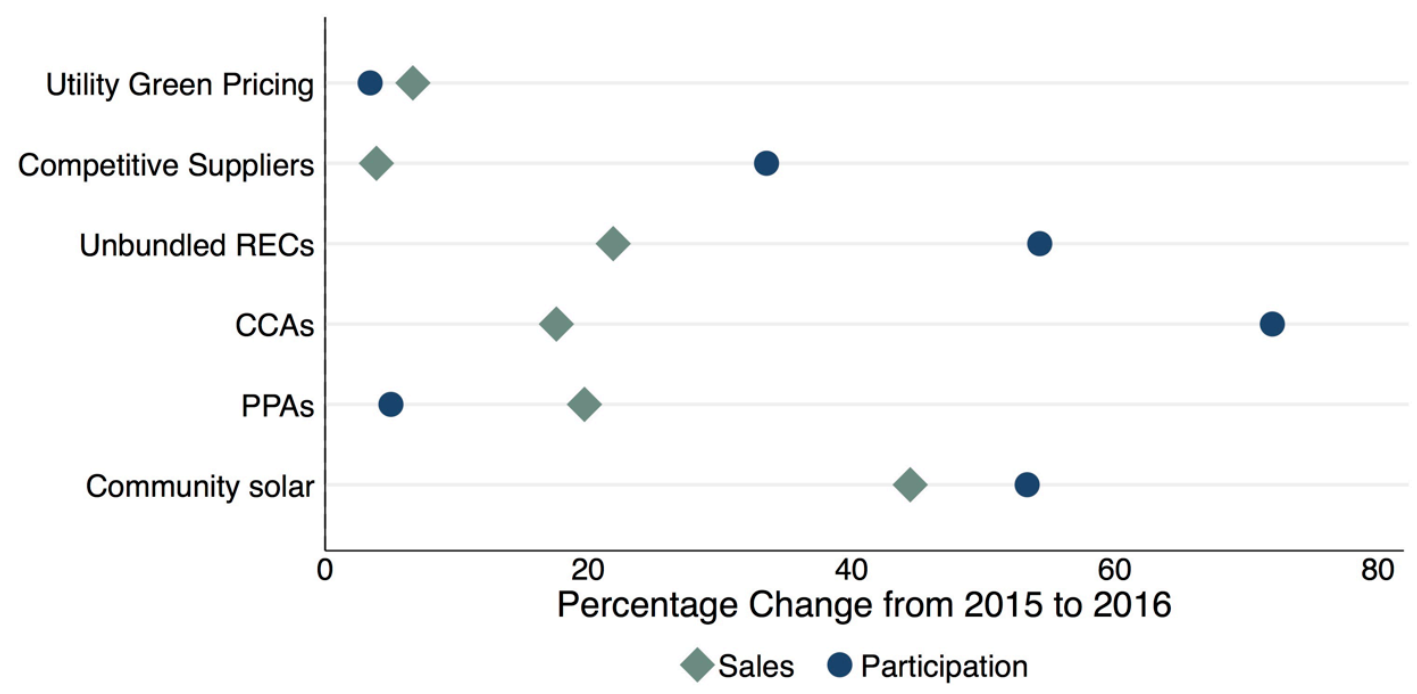

Figure 1. Percentage changes (2015-2016) in green power market participation and sales 
Green power sales have generally increased over time, in part because sales within certain mechanisms have increased, but also because new mechanisms have become available over time (Table 4, Figure 2). Sales growth has been relatively steady in green pricing programs and competitive suppliers, and more pronounced in relatively newer markets such as PPAs and community solar.

Table 4. Estimated Green Power Sales (millions of MWh), 2010-2016 ${ }^{\mathrm{a}}$

\begin{tabular}{llllllll}
\hline Green power option & $\mathbf{2 0 1 0}$ & $\mathbf{2 0 1 1}^{\mathbf{b}}$ & $\mathbf{2 0 1 2}$ & $\mathbf{2 0 1 3}$ & $\mathbf{2 0 1 4}$ & $\mathbf{2 0 1 5}$ & $\mathbf{2 0 1 6}$ \\
\hline Utility green pricing & 5.4 & 5.8 & 6.0 & 6.9 & 7.0 & 7.5 & 8.0 \\
Utility contracts & 0 & 0 & 0 & 0.2 & 0.7 & 1.9 & 2.9 \\
Competitive suppliers & 10.4 & 11.0 & 11.6 & 14.5 & 16.2 & 15.4 & 16.0 \\
Unbundled RECs & 19.8 & 25.4 & 31.0 & 31.4 & 36.0 & 42.5 & 51.8 \\
CCAs & - & - & - & 8.1 & 7.7 & 7.4 & 8.7 \\
PPAs & 1.3 & 2.1 & 2.2 & 2.7 & 5.1 & 6.6 & 7.9 \\
Community solar & 0.005 & 0.050 & 0.080 & 0.100 & 0.150 & 0.180 & 0.260 \\
\hline Total $^{\mathrm{c}}$ & $\mathbf{3 7}$ & $\mathbf{4 4}$ & $\mathbf{5 1}$ & $\mathbf{6 4}$ & $\mathbf{7 2}$ & $\mathbf{8 0}$ & $\mathbf{9 5}$ \\
\hline
\end{tabular}

a Historical results may differ from previous reports because of methodology adjustments; dashes indicate that reliable estimates for historical data are unavailable.

${ }^{b}$ Utility green pricing and unbundled RECs data were not collected for 2011. Estimates for 2011 are based on the midpoint between 2010 and 2012.

${ }^{\mathrm{c}}$ The total does not include community solar outside of PG\&E program (customers typically do not retain the RECs).
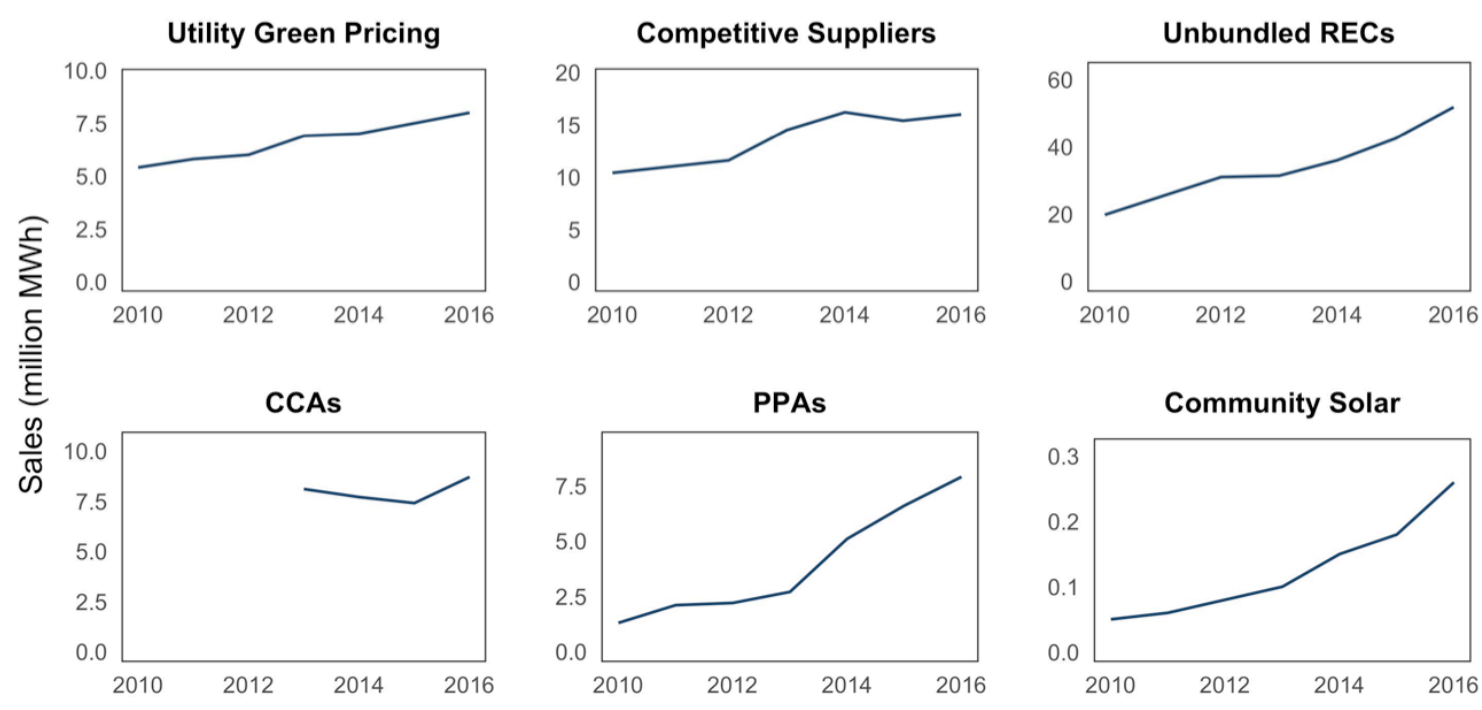

Figure 2. Green power sales by mechanism (2010-2016)

Plots are on different scales. Utility renewable contracts are excluded (most capacity came online in 2015). 
After declining for two years, green power participation increased by more than $50 \%$ from 2015 to 2016 (Table 5, Figure 3). The large increase in 2016 is primarily attributable to the expansion of CCAs in California and Massachusetts, where new programs began providing green power to large numbers of residential customers (Section 7).

Table 5. Estimated Green Power Participation (×1,000 customers), 2010-2016 ${ }^{\mathrm{a}}$

\begin{tabular}{lrrrrrrr}
\hline Green power option & $\mathbf{2 0 1 0}$ & $\mathbf{2 0 1 1}^{\mathbf{b}}$ & $\mathbf{2 0 1 2}$ & $\mathbf{2 0 1 3}$ & $\mathbf{2 0 1 4}$ & $\mathbf{2 0 1 5}$ & $\mathbf{2 0 1 6}$ \\
\hline Utility green pricing & 570 & 570 & 570 & 706 & 743 & 789 & 816 \\
Utility contracts & 0 & 0 & 0 & 0.001 & 0.001 & 0.001 & 0.001 \\
Competitive suppliers & 1,200 & 1,200 & 1,200 & 2,200 & 1,584 & 1,506 & 2,011 \\
Unbundled RECs & 60 & 85 & 110 & 95 & 89 & 70 & 108 \\
CCAs & - & - & - & 2,400 & 2,500 & 1,940 & 3,336 \\
PPAs & 0.09 & 0.13 & 0.15 & 0.17 & 0.18 & 0.20 & 0.21 \\
Community solar & 0.4 & 4 & 7 & 8 & 13 & 15 & 23 \\
\hline Total $^{c}$ & $\mathbf{1 , 8 3 0}$ & $\mathbf{1 , 8 5 5}$ & $\mathbf{1 , 8 8 0}$ & $\mathbf{5 , 4 0 1}$ & $\mathbf{4 , 9 1 6}$ & $\mathbf{4 , 3 0 5}$ & $\mathbf{6 , 2 7 6}$ \\
\hline
\end{tabular}

${ }^{\mathrm{a}}$ Historical results may differ from previous reports of methodology adjustments; dashes indicate that reliable estimates for historical data are unavailable.

${ }^{\mathrm{b}}$ Utility green pricing and unbundled RECs data were not collected for 2011. Estimates for 2011 are based on the midpoint between 2010 and 2012 .

${ }^{c}$ The total does not include community solar outside of PG\&E program (customers typically do not retain the RECs).
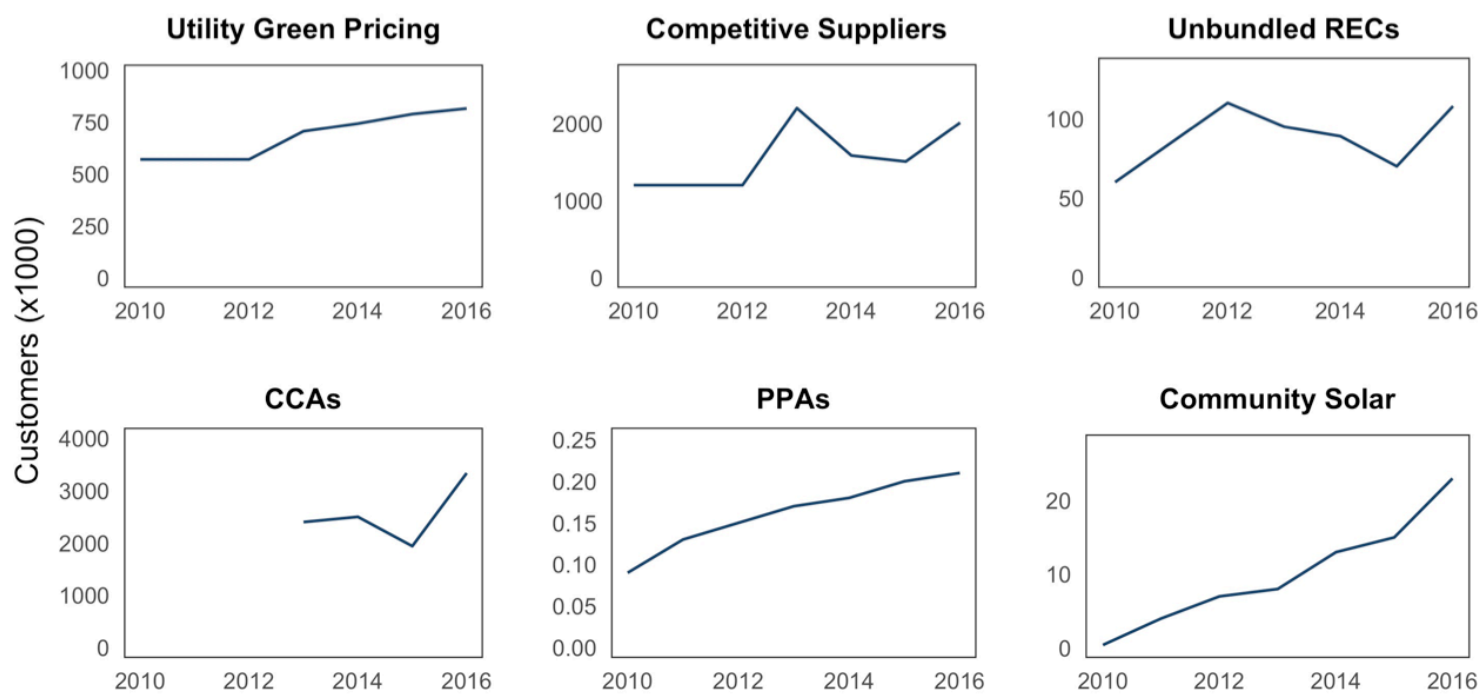

Figure 3. Green power participation by mechanism (2010-2016)

Plots are on different scales. Utility renewable contracts are excluded (most capacity came online in 2015). 
Unbundled RECs remain the largest source of green power sales, though the share of the market met by unbundled RECs fell beginning in 2012 because of the emergence of CCAs and PPAs (Figure 4). Green pricing programs, competitive suppliers, and CCAs - mechanisms that cater primarily to residential customers - comprise the majority of the green power customer base. CCAs now account for more than half of green power customers.
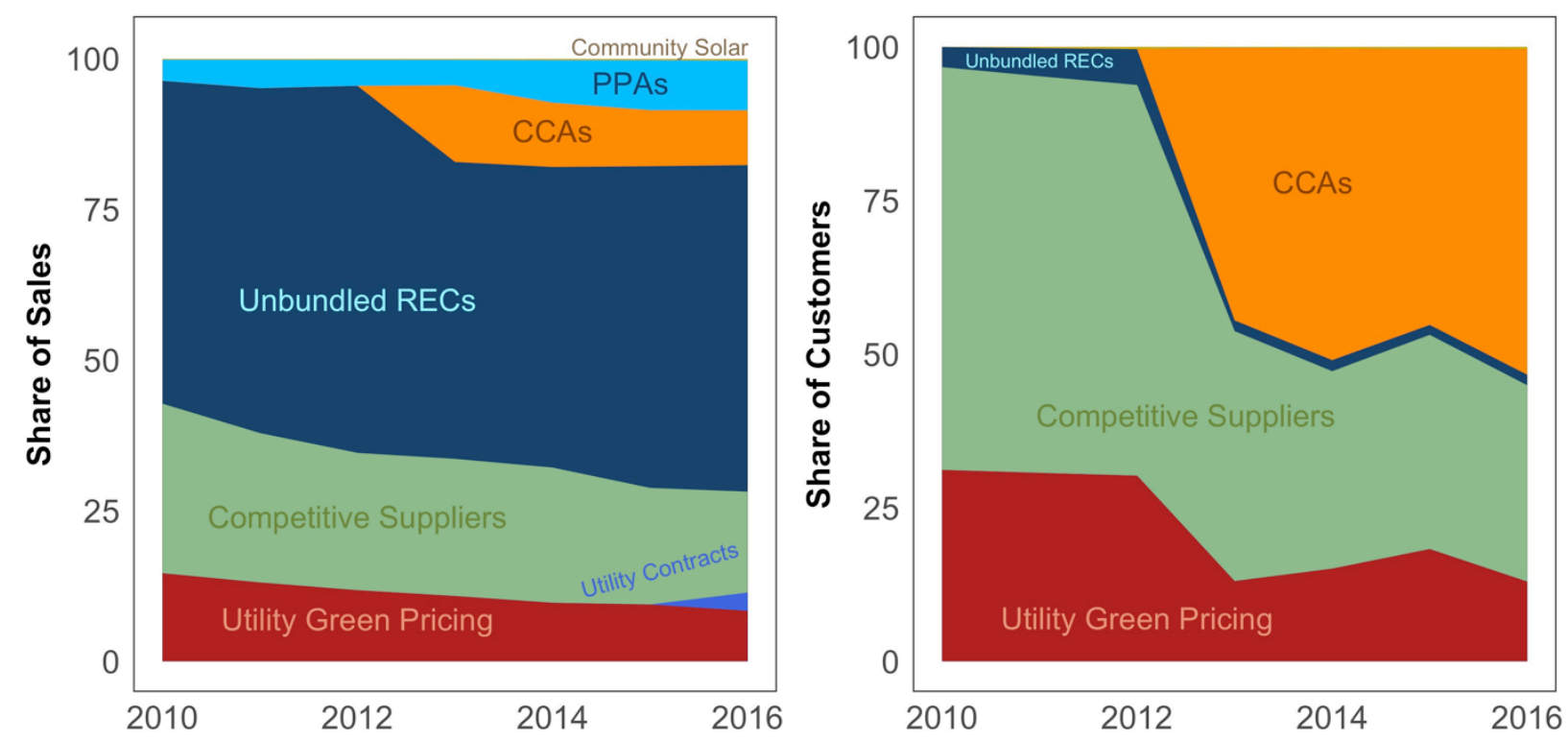

Figure 4. Shares of green power sales (left pane) and customers (right pane) over time by mechanism

Community solar, PPAs, and utility contracts collectively account for less than $1 \%$ of customers.

Figure 5 places the voluntary green power market in the context of the broader renewable energy market, excluding large hydropower. The majority of U.S. renewable energy sales are used to comply with state RPS programs. In 2016, compliance-based sales in state programs that require regulated entities to procure RECs from "new" projects accounted for about $42 \%$ of renewable energy sales, while compliance-based sales from existing projects accounted for about $26 \%$ of renewable energy sales in 2016 . The voluntary market accounted for about $28 \%$ of all U.S. nonhydro renewable energy sales in 2016. The group "other renewables" in Figure 5 includes utility renewable energy purchasing beyond RPS requirements and on-site generation. Compliancebased REC sales are based on data compiled by the Lawrence Berkeley National Laboratory (LBNL 2017). Total U.S. renewable energy sales are based on retail electricity sales data from the U.S. Energy Information Administration (EIA 2017). 


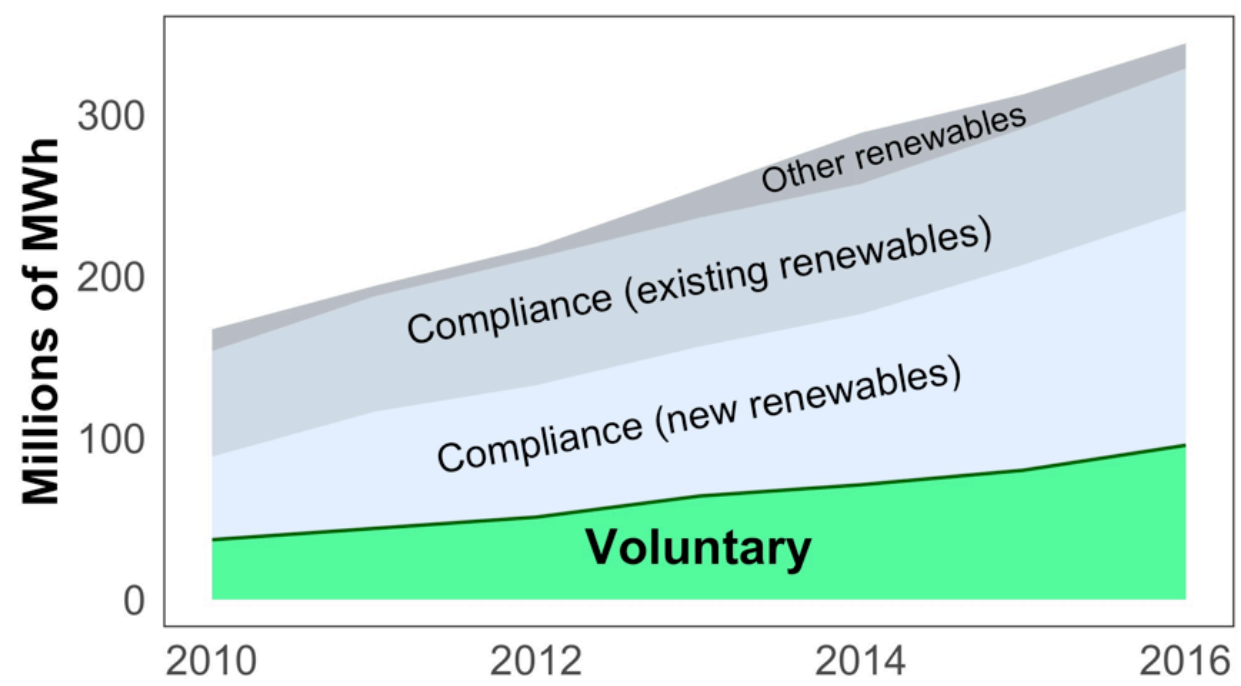

Figure 5. Renewable energy sales in voluntary, compliance, and other markets from 2010 to 2016 The figure is based on data from EIA 2017 and LBNL 2017. 


\section{Utility Green Pricing}

Many utilities sell green power to residential and non-residential customers through utility green pricing programs (Figure 6). In a typical green pricing structure, the utility generates or procures green power and retires RECs on behalf of the customer in proportion to the quantity of green power purchased by the customer. Green pricing customers generally pay for the green power through an additional line item on their utility bill. Green pricing sales and participation data in this report are based on data from a questionnaire sent to 42 utility green pricing programs.
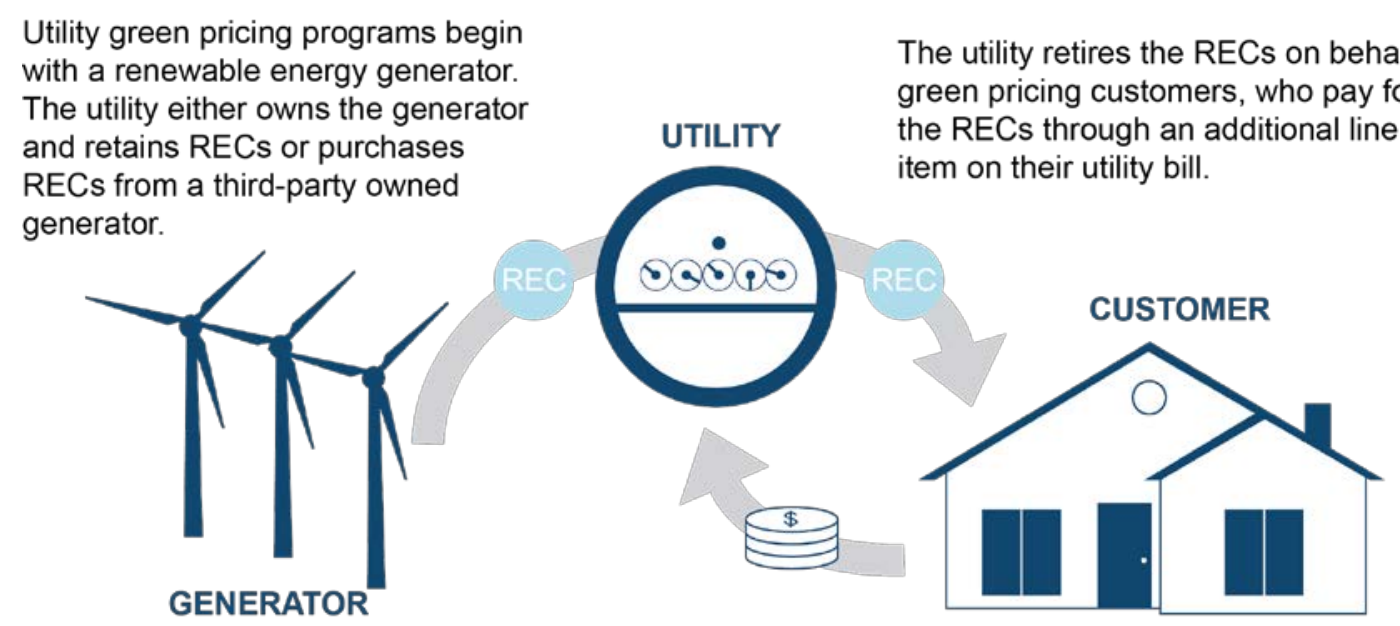

Figure 6. How utility green pricing programs work

The figure provides a simplified schematic for visualization purposes. Specific program structures vary.

\subsection{Status of Utility Green Pricing Programs}

In 2016, about 816,000 customers bought about eight million MWh of green power through utility green pricing programs (Figure 7). Utility green pricing programs continue to exhibit growth overall, as sales increased by 6\% from 2015 to 2016.

\section{Green Pricing Sales: 8 million MWh}

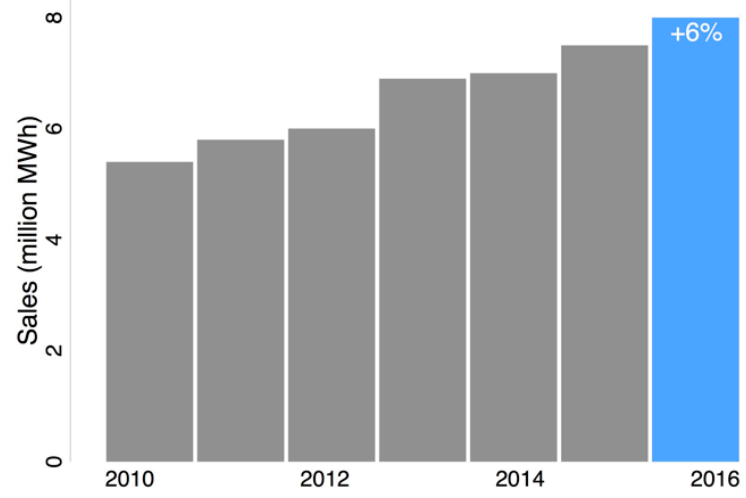

2016 Green Pricing Participation: 816,000 customers

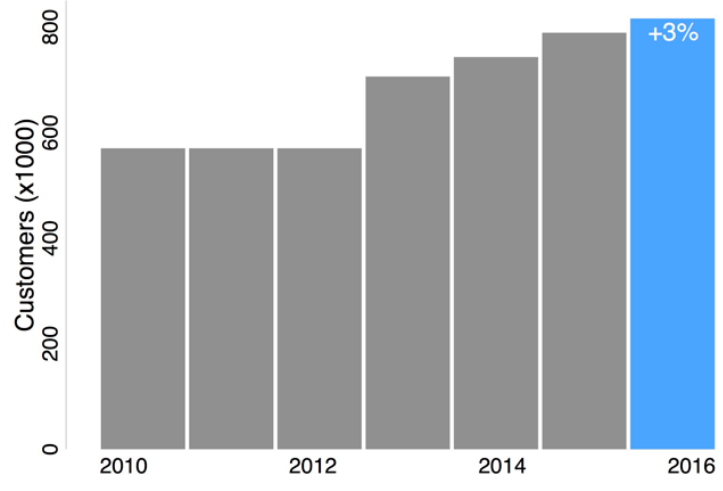

Figure 7. Utility green pricing program sales and participation from 2010 to 2016 


\subsection{Trends in Utility Green Pricing Programs}

Consistent with previous years, utility green pricing program sales continue to grow only because of the expansion of a few large programs. Large programs (>100,000 MWh/year) increased sales by about 7\% from 2015 to 2016, driving an increase in sales overall. Sales among all remaining programs dropped by about 5\% from 2015 to 2016 .

Utility green pricing program premiums ranged from $\$ 0.001 / \mathrm{kWh}$ to $\$ 0.05 / \mathrm{kWh}$ for both residential and non-residential customers (Figure 8). The average residential premium was about $\$ 0.018 / \mathrm{kWh}$, or about $\$ 195 /$ year based on average home electricity use. The average nonresidential premium was about $\$ 0.017 / \mathrm{kWh}$. Premiums vary for many reasons, such as technology and locational attributes of the renewable energy resource. For example, utility green pricing programs that offer local solar products typically charge higher premiums than programs that offer national wind products. Programs also offer a variety of premium structures. For instance, some programs offer tiered premiums that result in lower premiums for customers that purchase large quantities of green power.
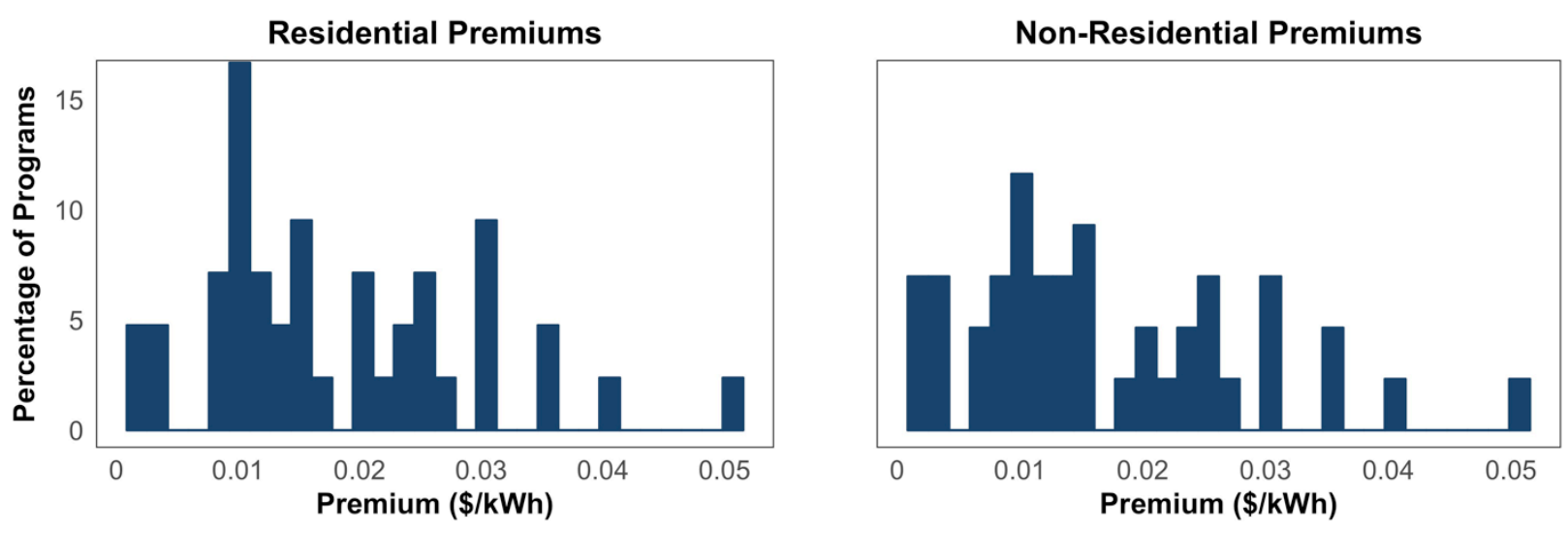

Figure 8. Distributions of utility green pricing program premiums

From 2015 to 2016, solar's share of green pricing program generation increased from $4 \%$ to $8 \%$, and landfill gas' share increased from $4 \%$ to $7 \%$. The shift toward solar and landfill gas may represent a broader shift toward local renewable resources. Wind remains the primary resource procured through utility green pricing programs (Figure 9).

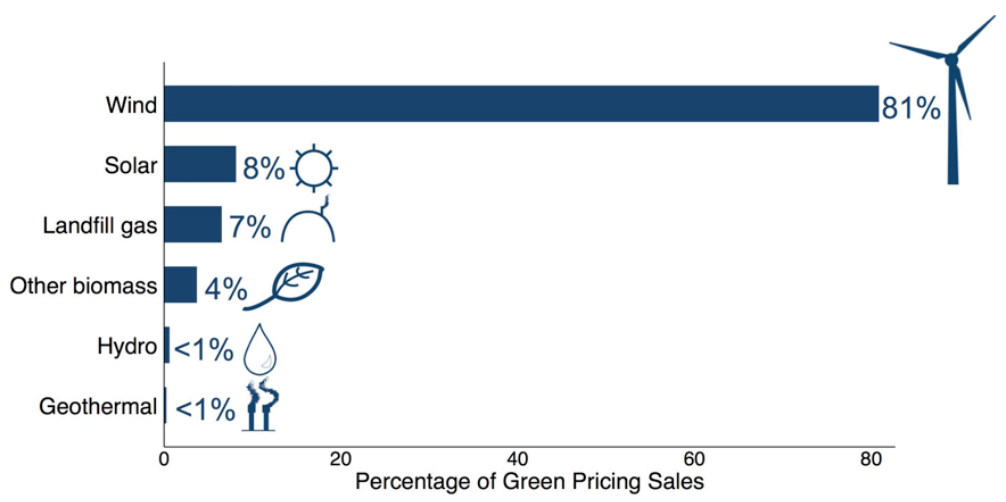

Figure 9. Utility green pricing program renewable energy resources 
Unbundled RECs remain the primary method for green power procurement in utility green pricing programs (Table 6), though the share of unbundled RECs fell by six percentage points from 2015 to 2016 . Green power procured through utility-owned projects and from utility customers increased from $4 \%$ to $10 \%$ from 2015 to 2016 . In terms of contract length (the duration of the REC purchasing period), more than half of RECs are procured through contracts of less than five years. RECs bundled with electricity or through projects owned by utilities are generally procured through longer-term ( $>5$ year) contracts.

Table 6. Contract Length by Type of Utility Green Power Procurement (MWh), 2015

\begin{tabular}{lcccc}
\hline $\begin{array}{l}\text { Contract } \\
\text { Length }\end{array}$ & $\begin{array}{c}\text { Unbundled } \\
\text { RECs (\%) }\end{array}$ & $\begin{array}{c}\text { RECs Bundled with } \\
\text { Electricity (\%) }\end{array}$ & $\begin{array}{c}\text { Projects Owned by } \\
\text { Utility (\%) }\end{array}$ & $\begin{array}{c}\text { RECs Produced by } \\
\text { Utility Consumers (\%) }\end{array}$ \\
\hline s1 year & 25.1 & $\sim 0.0$ & $\sim 0.0$ & 0.0 \\
2-5 years & 25.6 & 2.8 & 0.0 & 1.9 \\
6-10 years & 5.4 & 11.9 & 2.9 & 0.1 \\
$\geq 11$ years & 1.2 & 18.2 & 1.6 & 3.2 \\
\hline Percent of total & 57.0 & 33.0 & 5.0 & 5.0 \\
procurement & & & & \\
\hline
\end{tabular}

Many utilities with green pricing programs are considering developing new programs (i.e., new types of green pricing programs or other utility programs) to offer renewable energy to their customers. About $64 \%$ of utilities that provided information on their green pricing programs (27 programs) are considering a community solar program (Section 9), and about $7 \%$ are considering a utility renewable contract program (Section 4). 


\section{Utility Renewable Contracts}

Utilities have begun to offer more targeted renewable energy contractual offerings for large commercial customers outside their traditional green pricing programs. These utility contractual offerings may take the form of one-off bilateral agreements between a utility and a single customer or they may form part of a larger program known as a utility green tariff. We summarize key differences between bilateral agreements (Section 4.1) and utility green tariffs (Section 4.2), but for simplicity and for the purposes of this report, we group the two contractual approaches under the single label of utility renewable contracts. These utility renewable contracts are evolving and vary from utility to utility and, in the case of bilateral agreements, from project to project.

Utility renewable contracts differ from green pricing programs in three ways. First, renewable contract customers may, depending on the program structure, specify the resource and project from which to procure renewable energy. Second, customers pay for green power through a bilateral contract or green tariff rate rather than a premium added to the customer's existing service and get some credit for the energy and capacity provided by their renewable purchase. This second difference gives rise to the potential for future cost savings (relative to traditional utility rate) that are often not possible through green pricing programs. Third, utility renewable contracts are typically based on long-term agreements between customers, utilities, and generators. This enhances the customer's likelihood for future cost savings and allows generators to finance new projects. As a result of these three differences, utility renewable contracts are generally catered to or reserved for large non-residential customers who are willing to make longer-term and administratively complex contractual agreements with utilities in order to avoid the cost premiums associated with utility green pricing programs.

Utility renewable contract sales and participation estimates in this report are based on data from WRI (2017) and Heeter, Cook, and Bird (2017).

In a utility renewable contract, the customer enters into a contract with the utility to procure power and RECs from a renewable energy provider. Unlike green pricing programs, the customer may be able to specify the resource for the product.

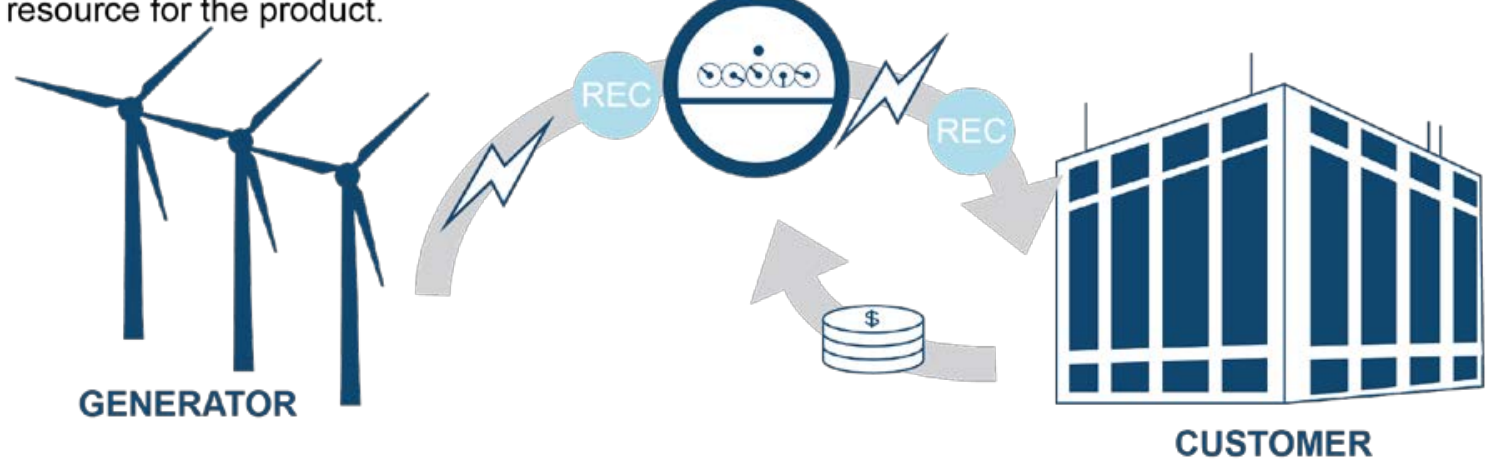

Figure 10. How utility renewable contracts work

The figure provides a simplified schematic for visualization purposes. Specific program structures may vary. Tariff structures may also vary within programs on a case-by-case basis. 


\subsection{Utility Bilateral Agreements}

In a bilateral agreement, a utility procures renewable energy on behalf of a single non-residential customer through a one-off contract. The terms of bilateral agreements are generally unavailable to other customers (Bonugli 2017); hence, bilateral agreements may vary from project to project even within the same utility. Bilateral agreements can be difficult to track, because capacity may not be publically disclosed.

At least 12 renewable energy projects have been contracted via a bilateral agreement through June 2017 (Table 7). ${ }^{1}$ Six projects have published contracted capacity, and these have a cumulative capacity of $745 \mathrm{MW}$. Of this capacity, $623 \mathrm{MW}$ of green power were contracted through bilateral contracts before 2016 and generated electricity in that year. ${ }^{2}$ In 2016 , these projects had a combined generation of 2,228,000 $\mathrm{MWh}^{3}$ This generation is likely to increase in 2017, assuming projects contracted in 2016 are constructed. Half of the bilateral agreements are in the Midwest (Table 7). Wind serves $623 \mathrm{MW}(84 \%)$ of the contracted capacity for the six projects that have published capacity and technology data.

Table 7. Bilateral Agreements for Renewable Energy by State, Company, and Utility

\begin{tabular}{|c|c|c|c|c|c|}
\hline State & Corporation & Utility & Project & Capacity & $\begin{array}{l}\text { Estimated } \\
\text { Contract } \\
\text { Year }\end{array}$ \\
\hline $\mathrm{AL}$ & Google & TVA & In development & Unknown & NA \\
\hline TN & Google & TVA & In development & Unknown & NA \\
\hline VA & Microsoft & $\begin{array}{l}\text { Dominion Virginia } \\
\text { Power }\end{array}$ & In development & $20 \mathrm{MW}$ & NA \\
\hline $\mathrm{AL}$ & Walmart & Alabama Power & $\begin{array}{l}\text { Lafayette Solar } \\
\text { Project }\end{array}$ & $72 \mathrm{MW}$ & 2016 \\
\hline GA & $\begin{array}{l}\text { Procter \& } \\
\text { Gamble }\end{array}$ & Georgia Power & $\begin{array}{l}\text { Constellation } \\
\text { Albany Biomass } \\
\text { Plant }\end{array}$ & $50 \mathrm{MW}$ & 2015 \\
\hline VA & $\begin{array}{l}\text { Amazon Web } \\
\text { Services }\end{array}$ & $\begin{array}{l}\text { Dominion Virginia } \\
\text { Power }\end{array}$ & $\begin{array}{l}\text { Amazon Solar } \\
\text { Farm }\end{array}$ & $80 \mathrm{MW}$ & 2015 \\
\hline IA & Google & $\begin{array}{l}\text { MidAmerican } \\
\text { Energy }\end{array}$ & Wind VIII Project & $407 \mathrm{MW}$ & 2014 \\
\hline IA & Facebook & $\begin{array}{l}\text { MidAmerican } \\
\text { Energy }\end{array}$ & $\begin{array}{l}\text { Wellsburg Wind } \\
\text { Project }\end{array}$ & $138 \mathrm{MW}$ & 2013 \\
\hline NE & Becton Dickinson & $\begin{array}{l}\text { Nebraska Public } \\
\text { Power District }\end{array}$ & $\begin{array}{l}\text { Steel City } \\
\text { Project (wind) }\end{array}$ & $30 \mathrm{MW}$ & 2013 \\
\hline
\end{tabular}

\footnotetext{
${ }^{1}$ NREL (2017)

${ }^{2}$ Though the Constellation Albany biomass plant was contracted in 2015, it has not yet come online.

${ }^{3}$ Electricity generation was sourced from SNL Financial Inc. data.
} 


\begin{tabular}{llllll}
\hline State & Corporation & Utility & Project & Capacity & $\begin{array}{l}\text { Estimated } \\
\text { Contract } \\
\text { Year }\end{array}$ \\
\hline OK & Google & $\begin{array}{l}\text { Grand River Dam } \\
\text { Authority }\end{array}$ & $\begin{array}{l}\text { Canadian Hills } \\
\text { Wind }\end{array}$ & $48 \mathrm{MW}$ & 2012 \\
\hline AZ & IO & $\begin{array}{l}\text { Arizona Public } \\
\text { Service }\end{array}$ & $\begin{array}{l}\text { Mix of 95\% wind } \\
\text { and 5\% solar }\end{array}$ & Unknown & Unknown \\
AZ & EBay & $\begin{array}{l}\text { Arizona Public } \\
\text { Service }\end{array}$ & Not disclosed & Unknown & Unknown \\
\hline
\end{tabular}

Source: Heeter, Cook, and Bird 2017

\subsection{Utility Green Tariff Programs}

Utility green tariffs are programs that allow customers to switch to new tariff rates to procure renewable energy via the utility. Unlike bilateral agreements, utility green tariffs are available to a class of customers and allow multiple customers to procure renewable energy under the same terms (Bonugli 2017).

Utility green tariff program designs vary, but eligibility criteria generally limit these programs to large non-residential customers. By the end of 2016, $599 \mathrm{MW}$ of renewable energy capacity had been procured through utility green tariffs, with $279 \mathrm{MW}$ contracted in 2016 alone (WRI 2017). ${ }^{4}$ An additional $360 \mathrm{MW}$ has been contracted in 2017, which lends to a cumulative total of 959 MW of contracted capacity. Another $465 \mathrm{MW}$ of project capacity is anticipated to be under negotiation (WRI 2017). For those projects that were contracted before 2016 (320 MW), we estimate about 702,000 MWh of green power generation in 2016.

\footnotetext{
${ }^{4}$ The WRI data are augmented by the inclusion of Microsoft's agreement with Black Hills Corporation to purchase wind from the 59-MW Happy Jack and Silver Sage wind farms (Smith 2016).
} 
Twelve utilities in twelve states offer utility green tariffs, with Kentucky, Nebraska, Michigan, Minnesota, Nebraska, and Wisconsin adding new programs in 2017 (Figure 11). The NV Energy Green Energy Rider has resulted in the most contracted green power capacity to date, with $449 \mathrm{MW}$ of contracted renewable energy capacity (all PV) by June 2017 (Figure 12).

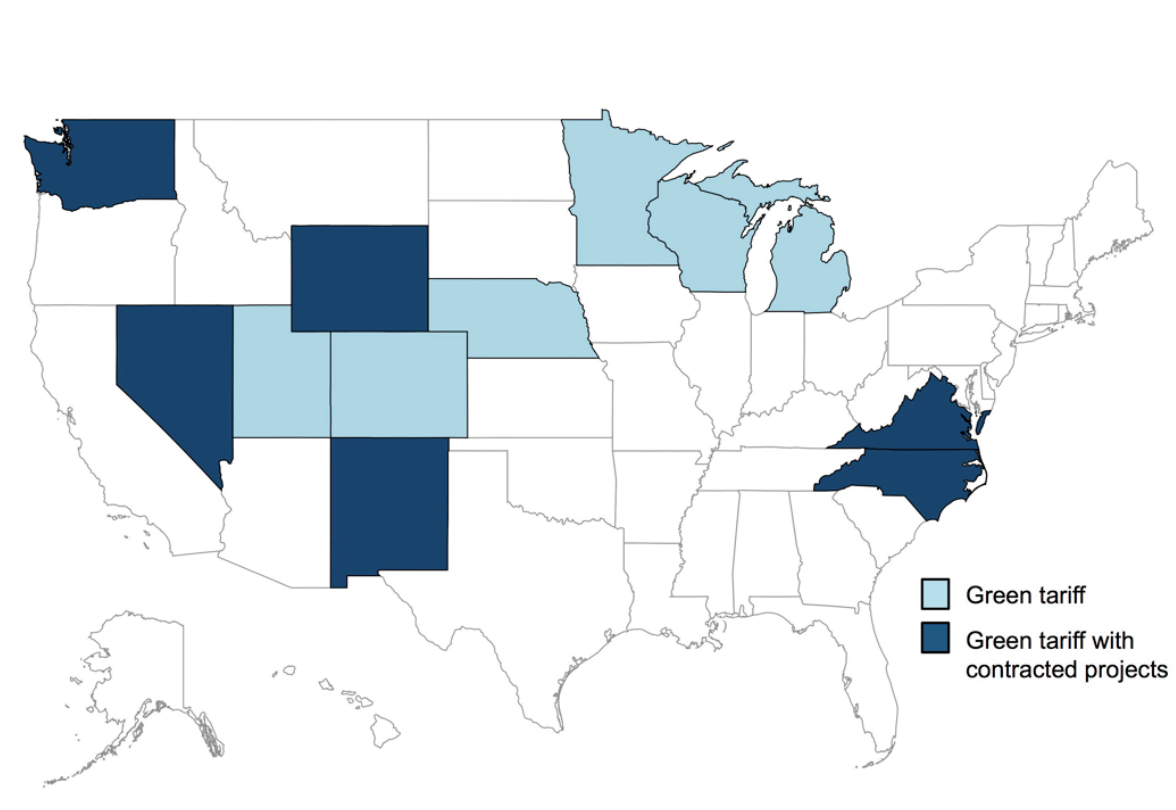

Figure 11. Utility green tariff programs
CO: Xcel Energy - Renewable*Connect

\author{
MI: Consumers Energy Company - \\ Voluntary Large Customer Program \\ MN: Xcel Energy - Renewable*Connect \\ NC: Duke Energy - Green Source Rider \\ NE: Omaha Public Power District - \\ Schedule No. 261 \\ NM: Public Service Company of New \\ Mexico - Green Energy Rider \\ NV: NV Energy - Green Energy Rider \\ UT: Rocky Mountain Power - Service \\ from Renewable Energy Facilities \\ VA: Dominion Virginia Power - \\ Renewable Energy Supply Service \\ WA: Puget Sound Energy - Long Term \\ Renewable Energy Purchase Rider \\ WI: Madison Gas \& Electric - Renewable \\ Energy Rider \\ WY: Black Hills Energy - Large Power
} Contract Service

Map based on information from Tawney et al. 2017

Of the $900 \mathrm{MW}$ of contracted capacity through 2017, $730 \mathrm{MW}$ are associated with solar projects. The remaining $130 \mathrm{MW}$ are contracted with one wind project to serve Puget Sound Energy's program in Washington state (WRI 2017). It is unclear whether solar will continue to dominate the green tariff market, given the $465 \mathrm{MW}$ of capacity under negotiation. With several Midwestern states beginning to offer programs, future contracted capacity may rely on wind, which has a higher resource potential in those states. If the negotiated capacity is added, green tariffs may surpass bilateral agreements as the top utility renewable contract pathway for procuring renewable energy, in terms of capacity. 
Figure 12 illustrates total contracted capacity through utility renewable contracts - through both utility bilateral agreements and utility green tariff programs - by state.

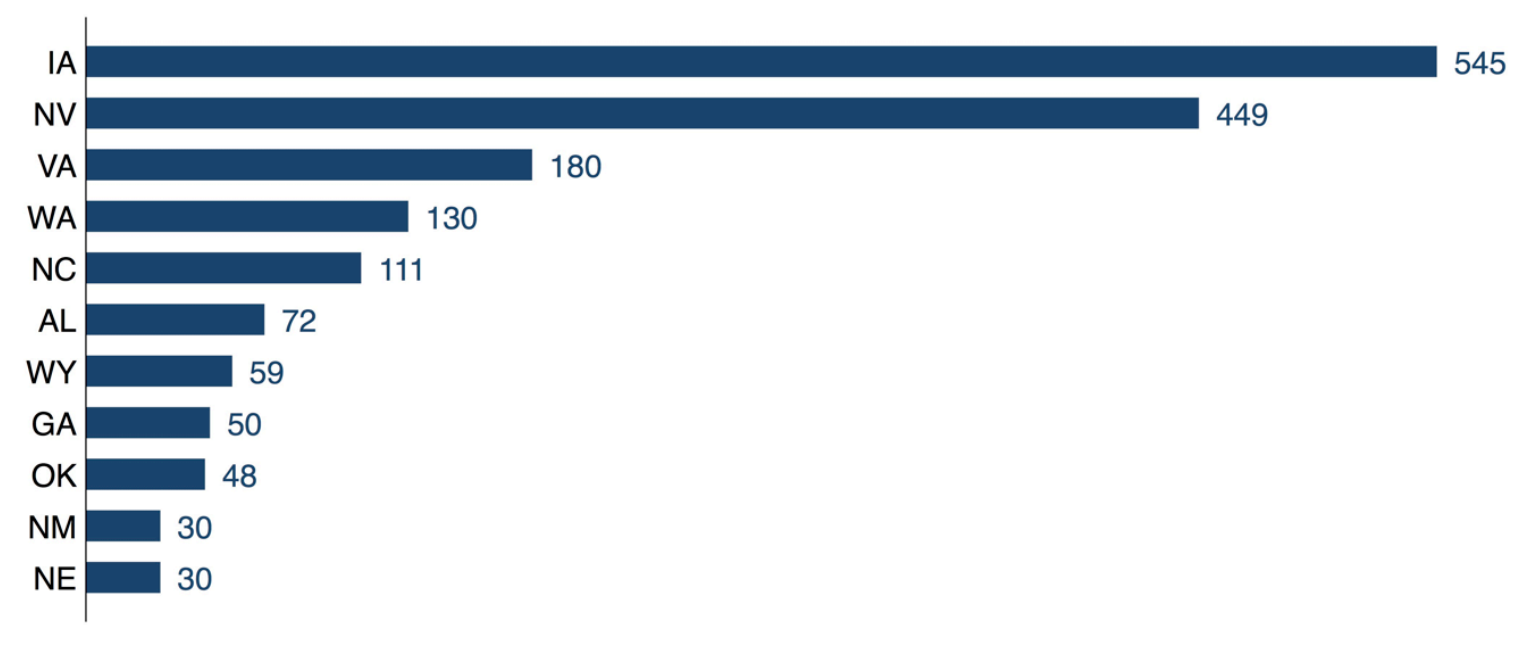

Figure 12. Cumulative utility renewable contract capacity by state (MW) 


\section{Competitive Suppliers}

In restructured electricity markets, customers can choose their electricity service from a competitive supplier, many of whom now offer a green power rate (Figure 13). Some suppliers only offer products with high renewable content, while others offer products with only nominally more renewables than required by state renewable portfolio standards. Competitive supplier sales and participation estimates in this report are based on data from a sample of six competitive suppliers and publically available data from ERCOT.

In restructured electricity markets, customers may choose a competitive electricity supplier that offers a green power product.

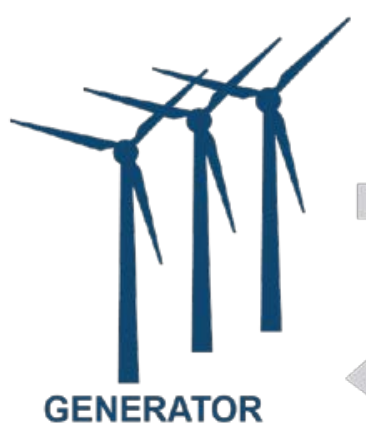

\section{COMPETITIVE SUPPLIER}

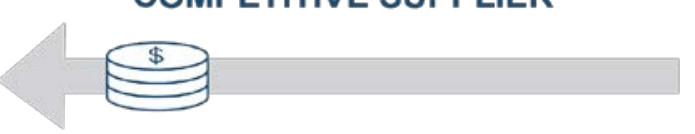

The competitive supplier provides the customer with power and RECs. The utility remains responsible for transmission and distribution. The competitive supplier may charge a premium for the green power product.

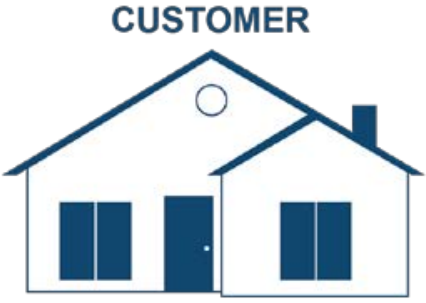

Figure 13. How competitive suppliers work

The figure provides a simplified schematic for visualization purposes. Specific transactions may vary.

\subsection{Status of Competitive Supplier Green Power}

In 2016, competitive suppliers sold about 16 million MWh of renewable energy to about 2 million customers (Figure 14).

\section{Competitive Supplier Sales:} 16 million MWh

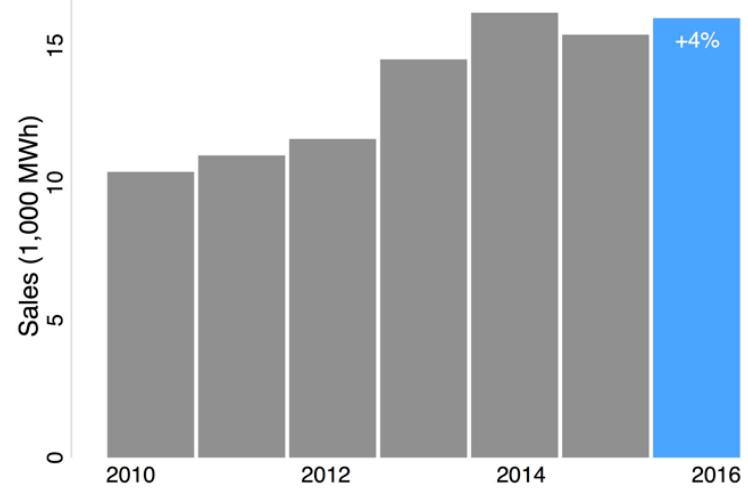

2016 Competitive Supplier Participation: 2 million customers

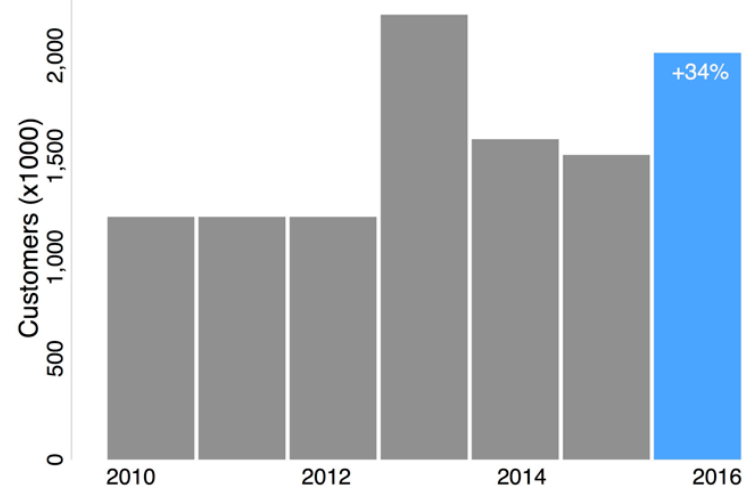

Figure 14. Competitive supplier sales and participation from 2010 to 2016 


\subsection{Trends in Competitive Supplier Green Power}

Competitive supplier green power estimates rely on responses to a questionnaire from a small sample of suppliers and publicly available data from ERCOT. Extrapolating from these samples to the national level obscures any granular trends in the data. ${ }^{5}$ This year's sales estimate is roughly consistent with estimates from previous years; however, this year's estimate for participation suggests a significant increase in the number of customers (Figure 14). Due to data limitations, it is difficult to interpret these trends. The increase in the number of customers may be due to actual trends and possibly a shift toward more residential customers from 2015 to 2016. However, this trend may also be a result of data noise owing to the small sample size.

One evident trend is that Texas wind is the primary source of green power for the national competitive supplier market. In 2016, nearly 25 million MWh of RECs were retired in ERCOT for voluntary purposes, including competitive supplier RECs and retirements for other voluntary RECs. Due to low cost wind resources, Texas also provides the largest source of unbundled RECs to the national voluntary market. In Figure 15, we present total voluntary REC retirements in ERCOT, by vintage. Retirements in 2016 (of any vintage REC) declined slightly from a high of 27 million MWh retired in 2015.

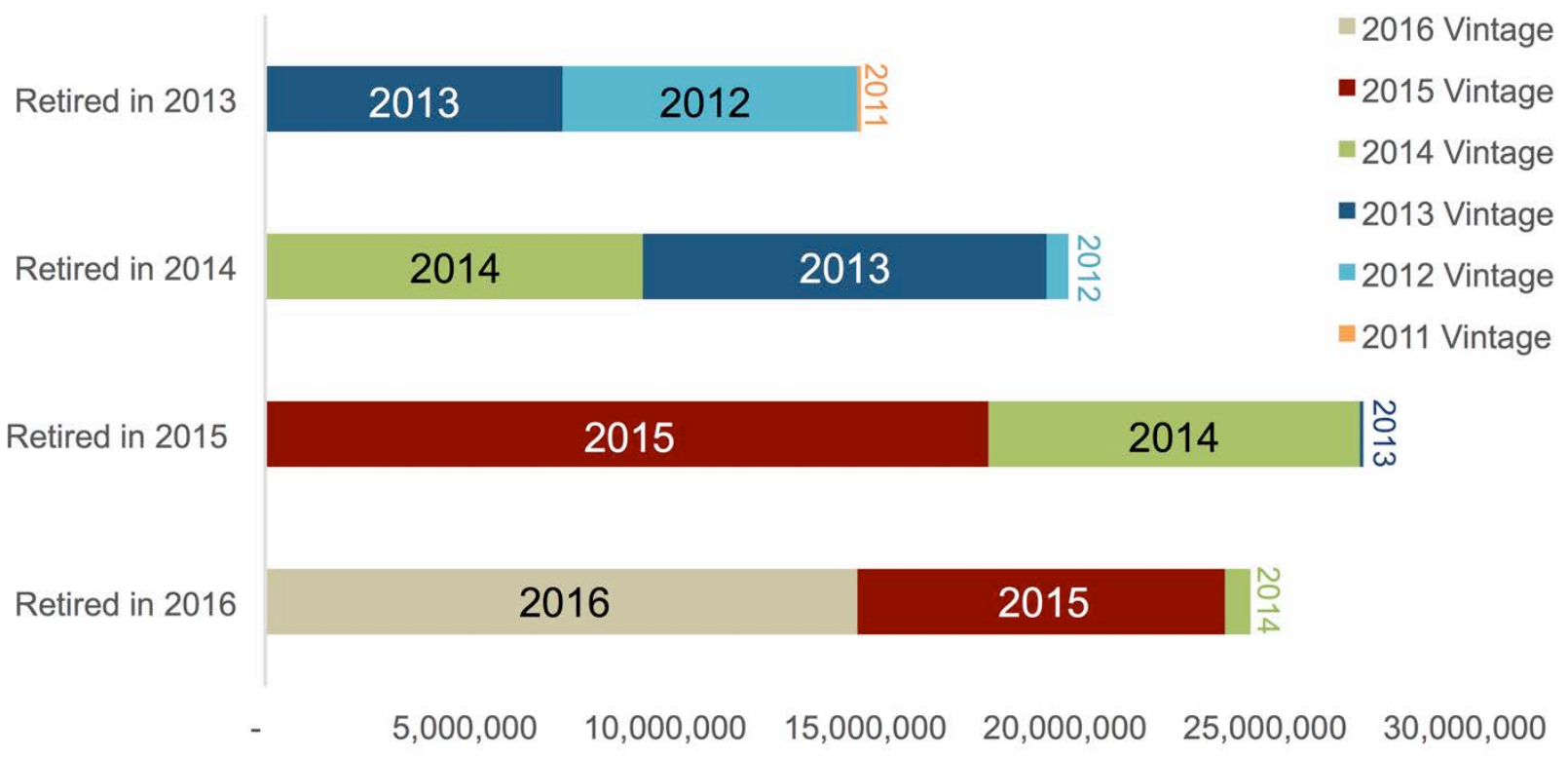

Figure 15. Voluntary REC retirements in ERCOT

Source: ERCOT 2017

\footnotetext{
${ }^{5}$ Historical estimates of competitive supplier sales and participation are affected by similar data limitations.
} 


\section{Unbundled RECs}

Some renewable energy generators sell electricity into local electricity markets without selling the associated RECs. RECs separated from the underlying electricity are known as unbundled RECs, and these may be sold into voluntary markets (Figure 16). Any electricity customer in the United States can buy unbundled RECs, typically through a third-party marketer. The unbundled RECs market is consistently the largest source of green power sales in the overall green power market. Unbundled RECs sales and participation estimates in this report are based on data provided by the Green-e national certification program (Leschke 2017).

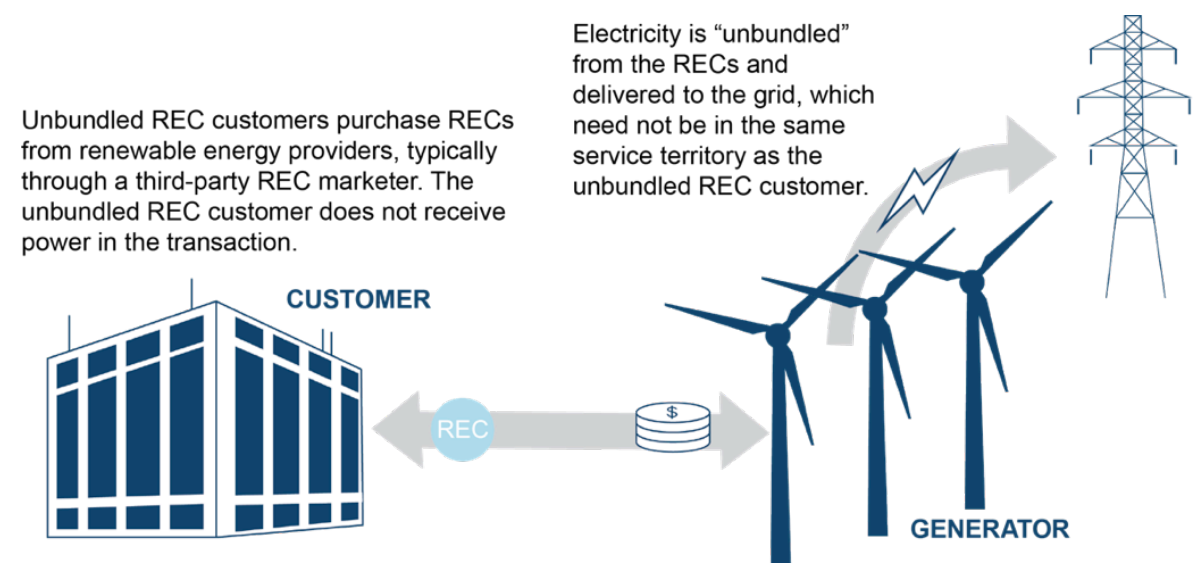

Figure 16. How unbundled RECs work

The figure provides a simplified schematic for visualization purposes. Specific transactions may vary.

\subsection{Status of Unbundled RECs}

We estimate that about 108,000 customers bought about 51.8 million MWh of green power through unbundled RECs in 2016 (Figure 17). The increase in customer numbers is likely due to more marketers actively targeting residential customers.

2016 Unbundled REC Sales:

51.8 million MWh

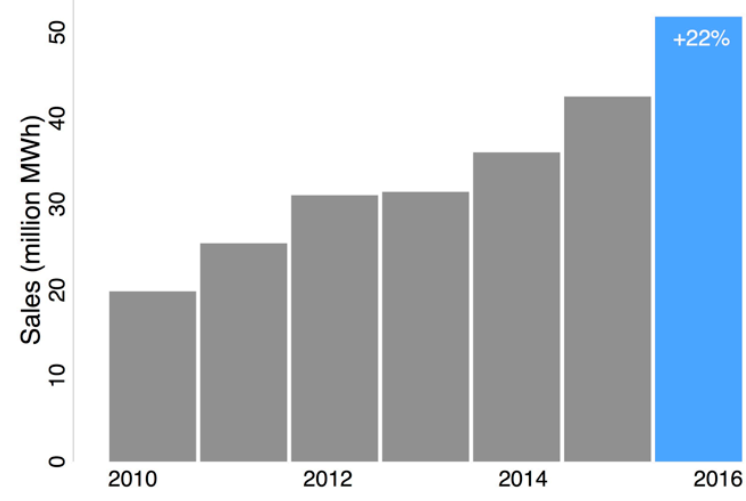

2016 Unbundled REC Participation: 108,000 customers

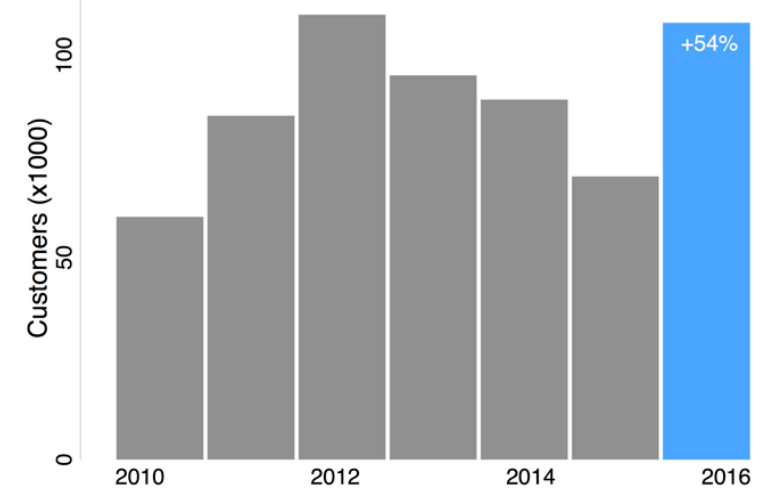

Figure 17. Unbundled REC sales and participation from 2010 to 2016 


\subsection{Trends in Unbundled RECs}

Customer participation in unbundled RECs increased by more than half from 2015 to 2016 , while sales increased by $22 \%$. The significant increase in participation from 2015 to 2016 was driven by more residential customers buying unbundled RECs, which is likely due to the efforts of some REC providers to aggressively market to residential customers who would otherwise purchase a utility green pricing product. In this section, we highlight two trends in unbundled REC markets: increased customer interest in renewable energy and continuation of low REC prices. We also present data on compliance REC pricing.

\section{Increased Large Customer Commitments to Renewable Energy}

The interest of large customers in unbundled RECs - part of a larger trend in other green power markets including PPAs - is one key driver behind sustained growth in unbundled REC sales. Large customers are continuing to make commitments to renewable energy and greenhouse gas reductions. As these companies start investigating renewable energy purchasing options, they often begin with an unbundled REC purchase, as the purchase has low transaction costs, does not require a long-term commitment, and is straightforward compared to an off-site PPA or participation in a green tariff.

In 2016 and 2017, more large corporate customers began making pledges through the RE100 Campaign, and the We Are Still In campaign, and the Buyers' Principles:

- Companies are increasingly making commitments to use $100 \%$ renewable energy through the RE100 Campaign. ${ }^{6}$ One hundred and six companies have made a commitment to use $100 \%$ renewable energy, though their end-year targets differ. Many companies signing on to RE100 are international companies committed to sourcing renewables in all of the countries they operate in, which is driving renewable demand across the globe (Bird et al. 2017).

- As of September 2017, more than 2,300 organizations had committed to climate action through the We are Still In pledge, which was launched in June $2017 .^{7}$ The organizations include more than 1,700 businesses and more than 200 cities and counties, as well as states, tribes, and colleges and universities.

- The Buyers' Principles are criteria to help companies meet their renewable energy goals. ${ }^{8}$ Companies support greater choice in procurement options, more access to cost competitive options, longer- and variable-term contracts, access to new projects, improved financing and contracting, and opportunities to work with utilities and regulators to expand renewable choices. Seventy companies had signed on to the Buyers' Principles as of September 2017, up from 62 companies in September 2016 and 43 companies in September 2015. And, the renewable demand from these companies had grown to 54 million MWh in September 2017, up from 45 million MWh in September 2016 and to 30 million MWh in September 2015.

Although it remains to be seen whether these companies all meet their commitments, the market will likely continue to grow in the near term, given low unbundled REC prices. More than 1,300 organizations are already buying renewable energy in some form and are participating in

\footnotetext{
${ }^{6} \mathrm{http}: / /$ there100.org/

7 https://www.wearestillin.com/

8 http://buyersprinciples.org/
} 
partnerships such as the EPA's Green Power Partnership, RE100, and the Buyers Principles (Figure 18).

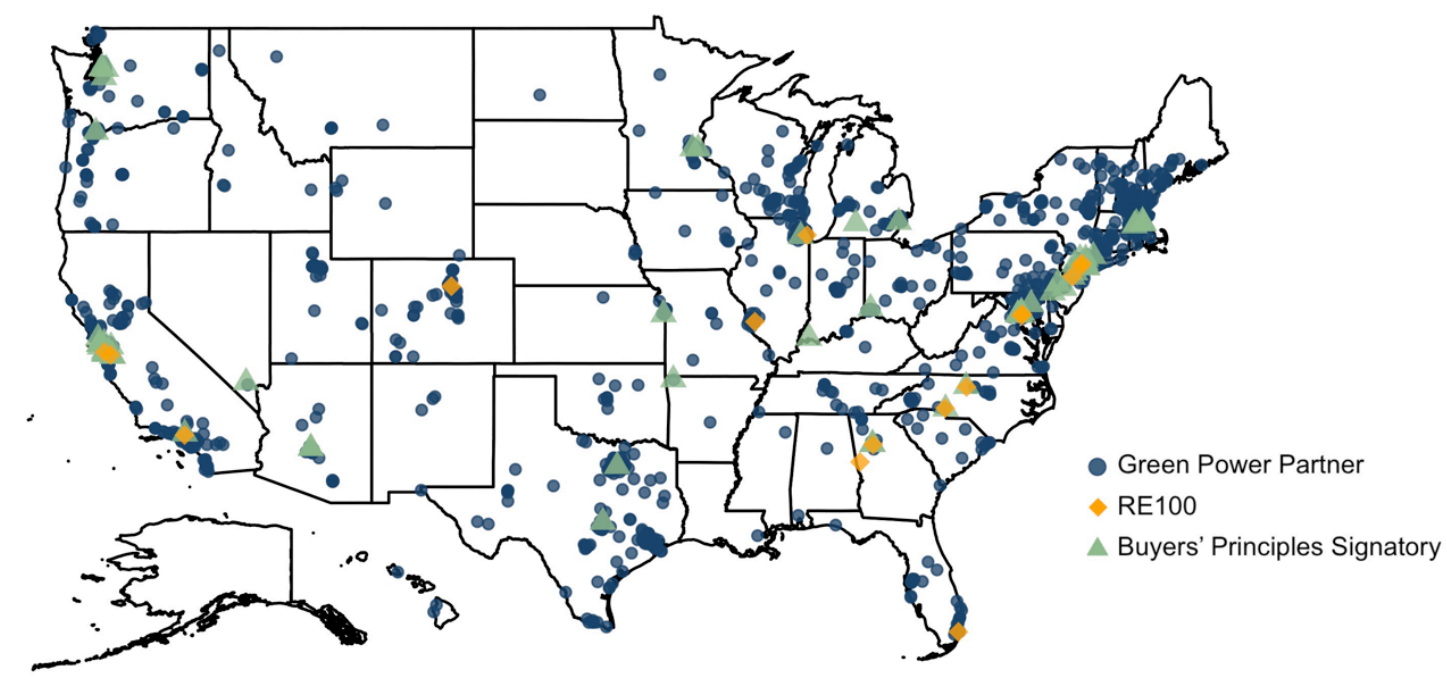

Figure 18. Large customer renewable energy commitments and purchasers

Map is based on information from WRI and WWF. n.d., EPA 2017, and RE100 2017. Location is generally based on corporate headquarters.

\section{REC Pricing Trends}

REC prices continued to remain low throughout 2016, after peaking at around $\$ 1.13 / \mathrm{MWh}^{9}$ in January 2014 (Figure 19). 2016 REC prices averaged around $\$ 0.35 / \mathrm{MWh}$. The continuation of low REC prices likely explains the increase in much of the unbundled RECs market from 2015 to 2016. Purchasers with a set budget for purchasing renewable energy can purchase more RECs at lower prices.

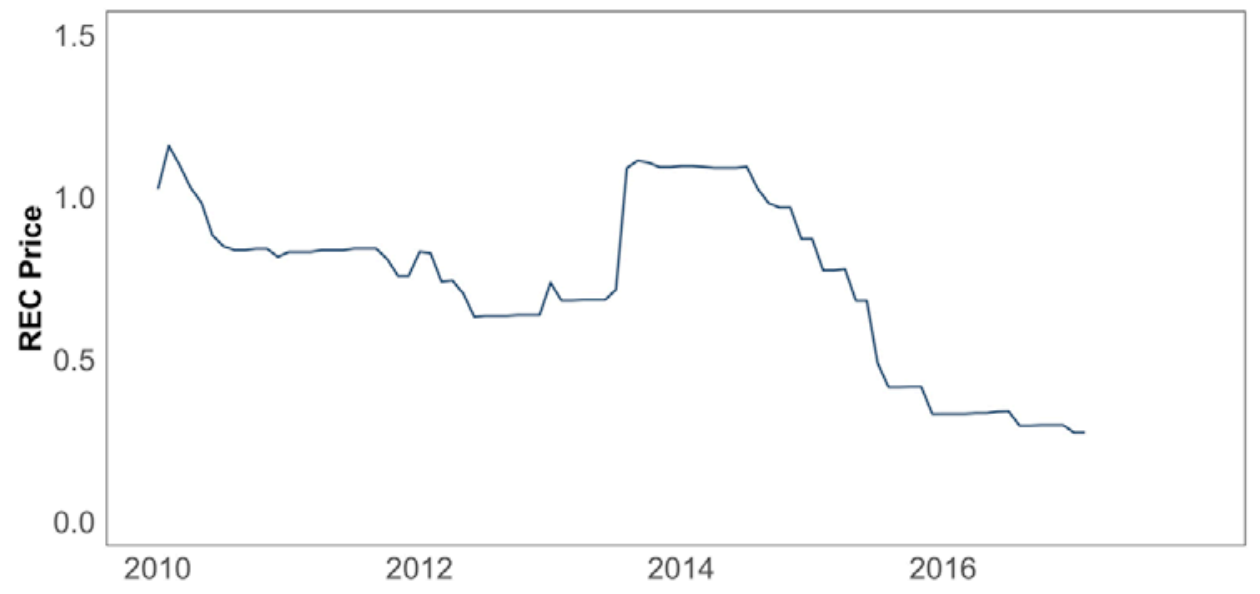

Figure 19. Voluntary national REC prices

Sources: SNL Energy 2017, Marex Spectron 2016

\footnotetext{
${ }^{9}$ A REC represents the clean energy attributes of one megawatt-hour of renewable energy generation. Hence, REC prices are commonly stated in terms of $\$ / M W h$, though the terminology is interchangeable with $\$ /$ REC.
} 
RECs used for voluntary purposes have different pricing than RECs used for RPS compliance. Prices for RECs used for compliance purposes tend to be higher due to RPS programs that require regulated entities to source RECs from specific states or regions. These restrictions limit the supply of eligible RECs while ensuring demand from load-serving entities, causing upward pressure on prices for RECs retired for compliance purposes.

Prices for REC used for RPS compliance continued to decline in 2016 in most states, with the greatest reductions coming in the historically high-priced New England states (Figure 20). For example, prices in New Hampshire declined from more than $\$ 45 / \mathrm{MWh}$ in 2015 to around \$25/MWh in early 2017. Prices in New England states tend to track together because state RPS rules generally allow RECs from anywhere within the New England Power Pool to be used for main tier compliance.

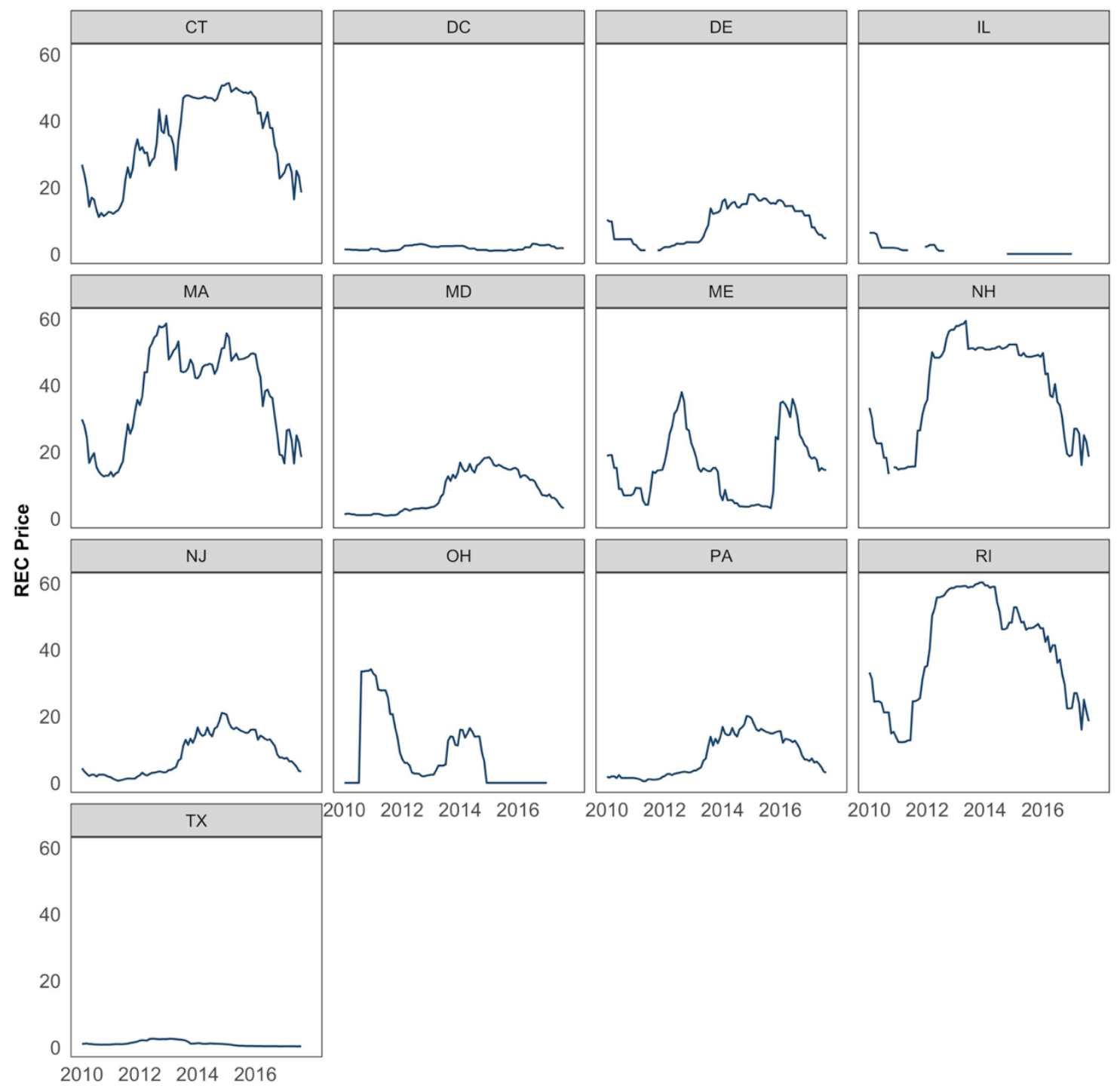

Figure 20. Prices of RECs used for compliance (excluding SRECs), January 2010_August 2017

Sources: SNL Energy 2017 and Marex Spectron 2016

Line breaks indicate missing data. The Ohio RPS program was frozen in 2015 and 2016. 
Some states have RPS carve-outs to support solar or distributed generation. Regulated entities use solar RECs (SRECs) to demonstrate compliance with solar-specific RPS requirements. SRECs are generally costlier than other compliance RECs due to limited supply of solar in SREC states. In Massachusetts and New Jersey, SREC prices fell from highs in 2015, while pricing in Washington, D.C. rebounded from a dip in late 2015 to record high levels by early 2017 (Figure 21). In Maryland, SREC prices saw a large drop from 2015 into 2016 as the market became oversupplied; in early 2017, SREC prices in Maryland were in the $\$ 10-\$ 15 / \mathrm{MWh}$ range, down from more than $\$ 150 / \mathrm{MWh}$ in 2015.

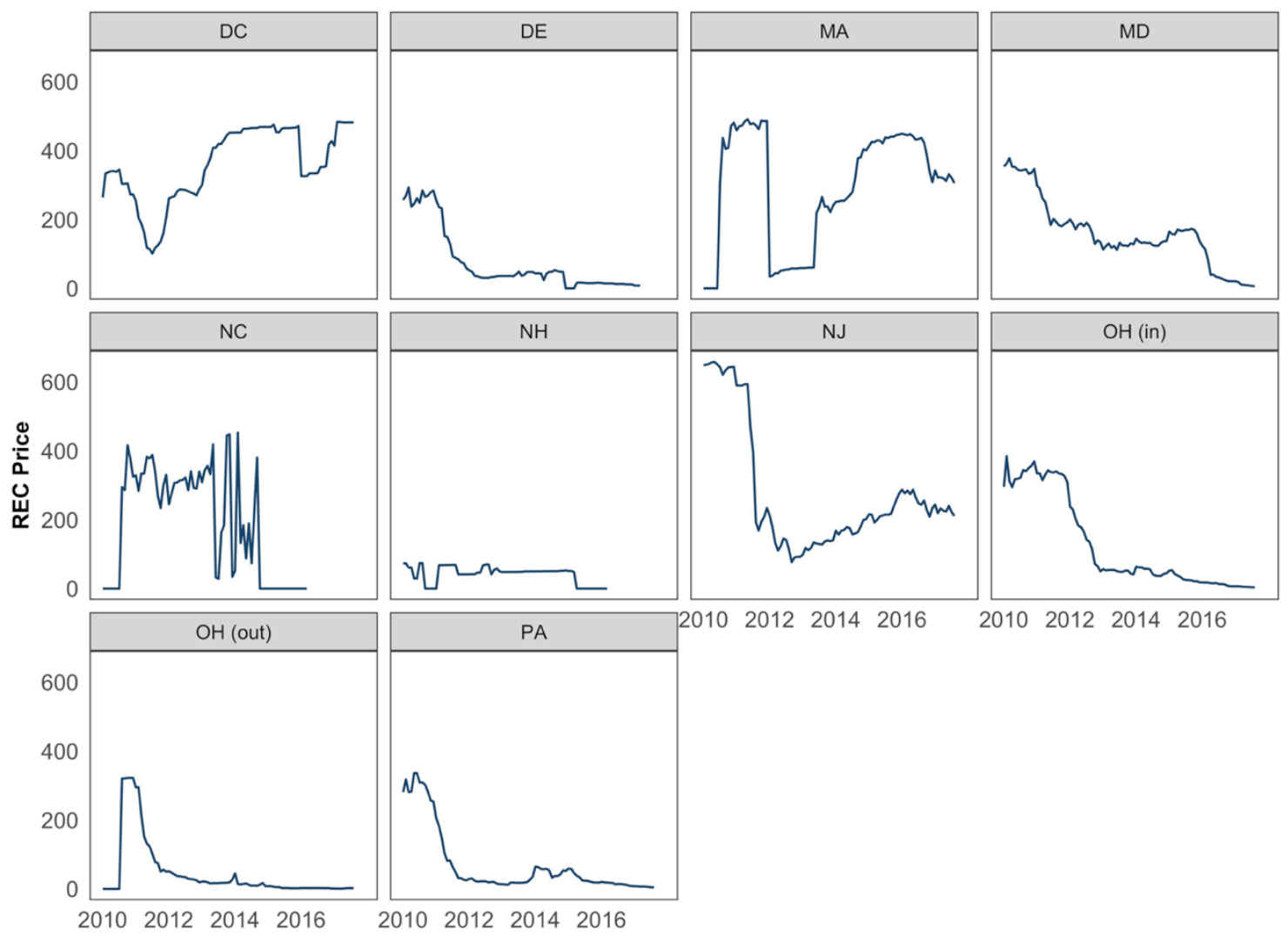

Figure 21. SREC pricing, January 2010-August 2017

Sources: SNL Energy 2017 and Marex Spectron 2016 


\section{Community Choice Aggregation}

Seven states to date have passed legislation that allows certain jurisdictions to form community choice aggregations (CCA). A CCA aggregates electricity customers within the jurisdiction to procure electricity and RECs from an alternative electricity supplier (Figure 22). In general, electricity customers are automatically enrolled in the electricity service selected by the CCA, although customers may opt out if they do not want to participate in the CCA. While CCAs can source their electricity from any generation type, several CCAs have procured green power products through alternative suppliers. CCAs may offer green power products either by default or as an optional premium package. CCA sales and participation estimates in this report are based on questionnaire responses (California, Massachusetts, New York, and Ohio) from publically available data (Illinois).

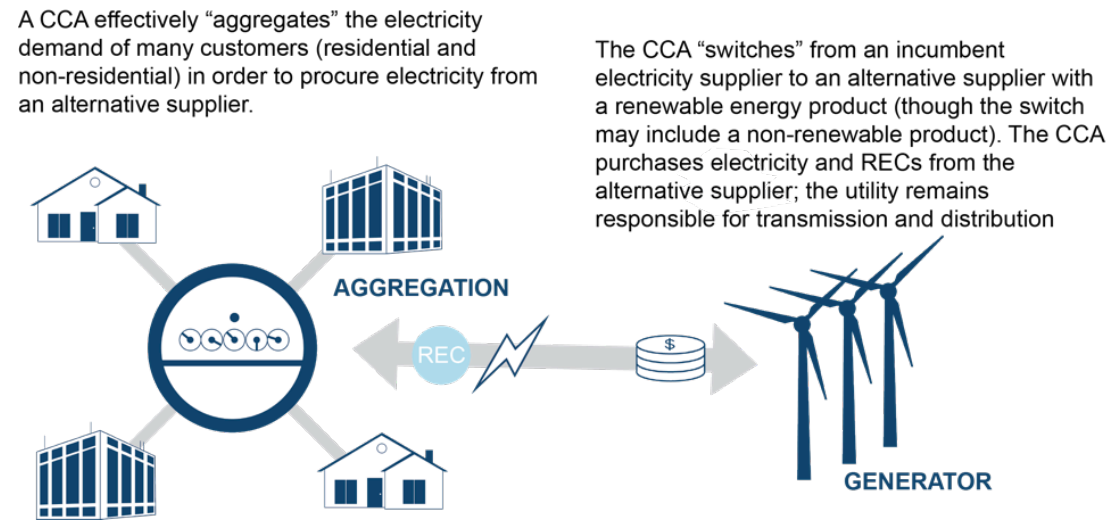

Figure 22. How community choice aggregation works

The figure provides a simplified schematic for visualization purposes. Specific program structures may vary.

\subsection{Status of CCAs}

In 2016, community choice aggregations sold about 8.7 million MWh of green power to about 3.3 million customers (Figure 23) in five states: California, Illinois, Massachusetts, New York, and Ohio.

2016 CCA Sales:

8.7 million MWh

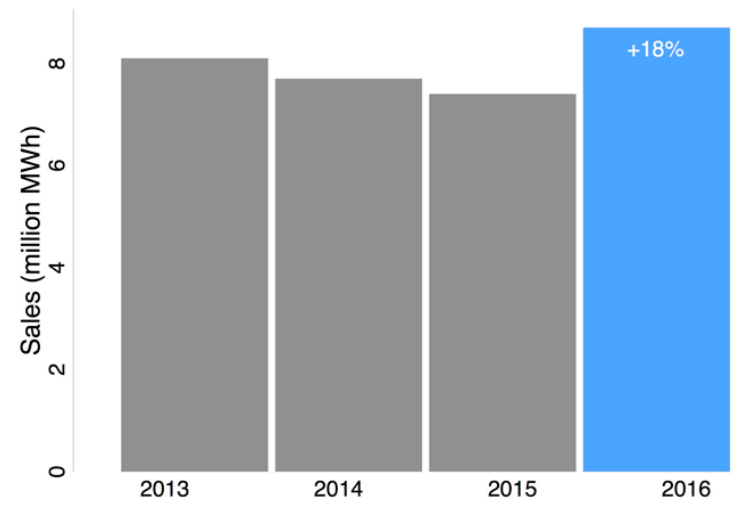

2016 CCA Participation:

\section{3 million customers}

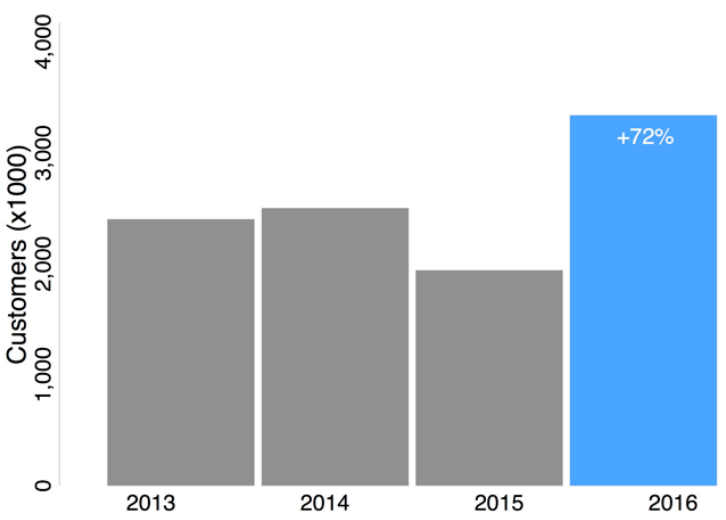

Figure 23. CCA sales and participation from 2013 to 2016 


\subsection{Trends in CCAs}

Green power sales and participation in CCAs increased from 2015 to 2016 in all five states with green power CCAs (Table 8). Illinois continues to lead the states with over two million CCA participants and its sales volume has remained relatively steady, while Massachusetts showed the largest increase in CCA participation on a percentage basis because of the addition of several new CCAs. California CCAs added the most green power sales in 2016. This section discusses trends in each of the five states with green power CCAs.

Table 8. CCA Green Power Sales and Participation by State in 2016

\begin{tabular}{|c|c|c|c|}
\hline State & $\begin{array}{l}\text { Estimated Green Power } \\
\text { Sales (MWh) } \\
(\% \Delta \text { from 2015) }\end{array}$ & $\begin{array}{l}\text { Participants in CCAs with } \\
\text { Green Power Products } \\
\text { (\% } \% \text { from 2015) }\end{array}$ & $\begin{array}{l}\text { CCAs with Green } \\
\text { Power Products } \\
\text { (as of 12/31/16) }\end{array}$ \\
\hline Illinois $^{a}$ & $\begin{array}{r}4,972,000 \\
(1 \%)\end{array}$ & $\begin{array}{r}1,909,997 \\
(32 \%)\end{array}$ & 62 programs \\
\hline California $^{\mathrm{b}}$ & $\begin{array}{r}2,574,000 \\
(56 \%)\end{array}$ & $\begin{array}{r}528,000 \\
(43 \%)\end{array}$ & $\begin{array}{l}\text { CleanPowerSF } \\
\text { Lancaster Choice } \\
\text { Energy } \\
\text { Marin Clean Energy } \\
\text { Sonoma Clean Power }\end{array}$ \\
\hline Ohio $^{b}$ & $\begin{array}{r}513,000 \\
(-12 \%)\end{array}$ & $\begin{array}{r}119,000 \\
(49 \%)\end{array}$ & $\begin{array}{l}\text { City of Cincinnati } \\
\text { City of Cleveland }\end{array}$ \\
\hline Massachusetts ${ }^{\mathrm{b}}$ & $\begin{array}{r}430,000 \\
(54 \%)\end{array}$ & $\begin{array}{l}673,000 \\
(2000 \%)\end{array}$ & 17 programs \\
\hline New York ${ }^{b}$ & 248,500 & 106,473 & $\begin{array}{l}\text { Sustainable } \\
\text { Westchester }\end{array}$ \\
\hline
\end{tabular}

${ }^{a}$ Estimate extrapolated from publicly available reports of green power products in CCAs applied to historical data on electricity usage

${ }^{\mathrm{b}}$ Based on data collected by NREL. Percentage changes are omitted because the program began in 2016.

\section{California}

California saw the largest jump in estimated green power sales year over year of any state where CCAs are available. One factor driving this trend was the rollout of CleanPowerSF in May 2016, which added over 75,000 customers. In addition, Marin Clean Energy expanded its service territory in September 2016 to include seven more municipalities, adding as many as 94,000 customers (Kaften 2016).

The California CCA market is likely to continue to grow as other municipalities implement new programs. In 2016, San Mateo County launched Peninsula Clean Energy, which currently serves all county residents with its ECOPlus (50\% renewable) and ECO100 (100\% renewable) programs (PCE 2017). Three other CCAs were formed in April and May 2017: Apple Valley Choice Energy, Redwood Coast Energy Authority, and Silicon Valley Clean Energy (Lean Energy U.S. 2017). 
A variety of municipalities and counties, including Los Angeles and San Diego counties are considering launching CCAs (Figure 24). If these and other interested jurisdictions establish CCAs, as much as $85 \%$ of California's electricity load could be served by CCAs, direct access, or customer sited generation by the mid-2020s (CPUC 2017a).

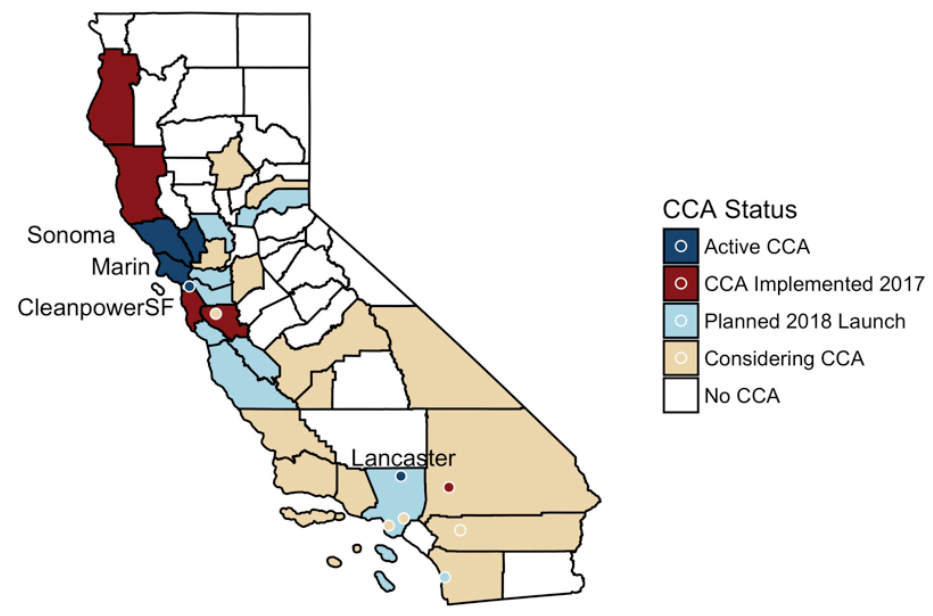

Figure 24. California CCAs

Figure based on information from Lean Energy U.S. 2017

Given these market dynamics, the CPUC held a hearing on CCAs with the California Energy Commission on May 19, 2017 to understand the potential impacts of CCA expansion (CPUC $2017 \mathrm{~b}$ ). The hearing focused on resource planning and cost allocation, among other topics. The CPUC has the authority to review utility resource plans and require long-term investments to meet state policy goals. It is unclear whether the CPUC has the same authority over CCAs. If not, staff argued this may limit the state's ability to achieve long-term policy goals, including reducing greenhouse gas emissions (CPUC 2017c).

In contrast, the CPUC has clearer authority to allocate costs across ratepayers, both utility ratepayers and those ratepayers leaving utilities for a CCA. The CPUC has approved utility requests to recover investments made to serve the load of departing CCA customers via the Power Charge Indifference Adjustment, also known as an exit fee. These exit fees are designed to allow utilities to recover stranded investments, including investments in solar and wind projects to meet historical and future RPS requirements. On June 29, 2017, the CPUC proposed a rulemaking to review and revise exit fees. While the outcome of this proceeding is uncertain, changes to the exit fees would influence the electricity rates offered by CCAs and how they compare to those of the regulated utility. Current CCA rates are marginally lower than those of the utility for at least some customer classes (Table 9). Exit fee increases could increase the number of new customers that decide to opt out of CCAs and remain with their existing utility service. For example, the CPUC authorized Pacific Gas \& Electric (PG\&E) to increase its exit fee to relevant CCA customers in late 2015. This exit fee increase may have contributed to a $27 \%$ increase in the percentage of customers opting out of CCAs between 2015 and 2016, according to NREL survey results. The average CCA dropout rate in California in 2016 was about $15 \%$. 
Table 9. Select CCA Residential Rate Comparison with Certain Utility Rates in California

\begin{tabular}{|c|c|c|c|c|c|c|c|c|}
\hline \multirow[b]{2}{*}{ Charges } & \multicolumn{2}{|c|}{ CleanPowerSF } & \multicolumn{2}{|c|}{$\begin{array}{c}\text { Lancaster Choice } \\
\text { Energy }\end{array}$} & \multicolumn{2}{|c|}{ Marin Clean Energy } & \multicolumn{2}{|c|}{$\begin{array}{c}\text { Sonoma Clean } \\
\text { Power }\end{array}$} \\
\hline & $\begin{array}{l}\text { PG\&E } \\
(30 \% \\
\text { RE) }\end{array}$ & $\begin{array}{l}\text { Green } \\
(40 \% \\
\text { RE) }\end{array}$ & $\begin{array}{l}\text { SCE } \\
(25 \% \\
\text { RE })\end{array}$ & $\begin{array}{l}\text { Clear } \\
\text { Choice } \\
(35 \% \\
\text { RE) }\end{array}$ & $\begin{array}{l}\text { PG\&E } \\
(30 \% \\
\text { RE) }\end{array}$ & $\begin{array}{l}\text { Light } \\
\text { Green } \\
(50 \% \\
\text { RE) }\end{array}$ & $\begin{array}{l}\text { PG\&E } \\
(30 \% \\
\text { RE) }\end{array}$ & $\begin{array}{l}\text { Clean } \\
\text { Start } \\
(36 \% \\
\text { RE) }\end{array}$ \\
\hline $\begin{array}{l}\text { Electric } \\
\text { Generation }\end{array}$ & $\$ 27.55$ & $\$ 19.14$ & $\$ 50.54$ & $\$ 43.09$ & $\$ 43.78$ & $\$ 32.04$ & $\$ 49.33$ & $\$ 36.21$ \\
\hline $\begin{array}{l}\text { PG\&E } \\
\text { Electric } \\
\text { Delivery }\end{array}$ & $\$ 43.51$ & $\$ 43.51$ & $\$ 85.64$ & $\$ 81.93$ & $\$ 61.75$ & $\$ 61.75$ & $\$ 71.03$ & $\$ 71.03$ \\
\hline $\begin{array}{l}\text { Additional } \\
\text { Charges } \\
\text { including exit } \\
\text { fees) }\end{array}$ & $\$ 4.66$ & $\$ 13.00$ & & $\$ 10.16$ & & $\$ 13.25$ & & $\$ 12.16$ \\
\hline Total & $\$ 75.72$ & $\$ 75.65$ & $\$ 136.19$ & $\$ 135.18$ & $\$ 105.53$ & $\$ 107.04$ & $\$ 120.36$ & $\$ 119.40$ \\
\hline $\begin{array}{l}\text { Key } \\
\text { Assumptions }\end{array}$ & \multicolumn{2}{|c|}{$\begin{array}{l}280 \mathrm{kWh} \text { on } \\
\mathrm{E}-1 \text { rate }\end{array}$} & \multicolumn{2}{|c|}{$\begin{array}{c}676 \mathrm{kWh} \text { on } \\
\text { Schedule D Rate }\end{array}$} & \multicolumn{2}{|c|}{$\begin{array}{c}445 \mathrm{kWh} \text { on } \\
\text { E-1 Rate }\end{array}$} & \multicolumn{2}{|c|}{$\begin{array}{c}510 \mathrm{kWh} \text { on } \\
\text { E-1 Rate }\end{array}$} \\
\hline
\end{tabular}

Sources: San Francisco Water Power Sewer 2017, Lancaster Choice Energy 2017, Pacific Gas \& Electric and MCE, 2017, and Sonoma Clean Power, 2017

CCAs may need to actively market benefits other than cost savings if their rates reach or exceed utility rates in order to retain customers. One marketable benefit could be fostering economic development through procuring local renewable generation. In 2017, Marin Clean Energy launched a new local solar option, Local Sol, in addition to its Light (50\% renewable) and Deep Green (100\% renewable) offerings (MCE 2017a). In this program, interested customers can purchase $100 \%$ renewable electricity from a solar project located within Marin Clean Energy's territory at about a 30\% cost premium to that of the Deep Green program. Marin Clean Energy markets the program as a local, green economic development tool that also offers guaranteed long-term rates the same as their other programs do (MCE 2017b). The performance of this and similar programs may be of interest to other CCAs.

\section{Illinois}

Illinois remains the state leader of green power CCA sales and participation. Sixty-two Illinois communities procured green power for over two million customers through CCAs by the end of 2015. Participation increased from 2015 to 2016, though many of these new customers are enrolled in CCAs with $50 \%$ or lower renewable energy content products. Further, despite an initial surge in green power sales around 2013, CCA green power sales have been stagnant in Illinois for the past several years. Slow movement of CCA green power sales is driven in part by communities allowing green power contracts to expire without renewal. Figure 25 illustrates changes in program status over time for Illinois CCAs. Of 98 communities that procured green power through CCAs at the beginning of 2014, only 45 communities maintained their green power programs through the end of 2016, 50 CCAs canceled their green power procurement and three programs reduced their green power procurement level from $100 \%$ to $50 \%$ or a customer opt-in. Over the same timeframe, only 14 communities formed new CCAs with green power 
products. These trends are mostly associated with the changing economics of green power options. Illinois CCAs initially offered highly competitive rates (2011-2013), contributing to the rapid expansion of CCAs in the state and allowing many CCAs to successfully market green power products. However, CCA rates became less competitive over time (2014-2015), undermining the value proposition of CCAs and reducing the attractiveness of green power options (Lean Energy U.S. 2017).

Illinois green power CCAs appear to show some spatial trends. For example, green power CCAs are popular around Chicago and Peoria but relatively absent in other metropolitan areas such as Rockford and Champaign.

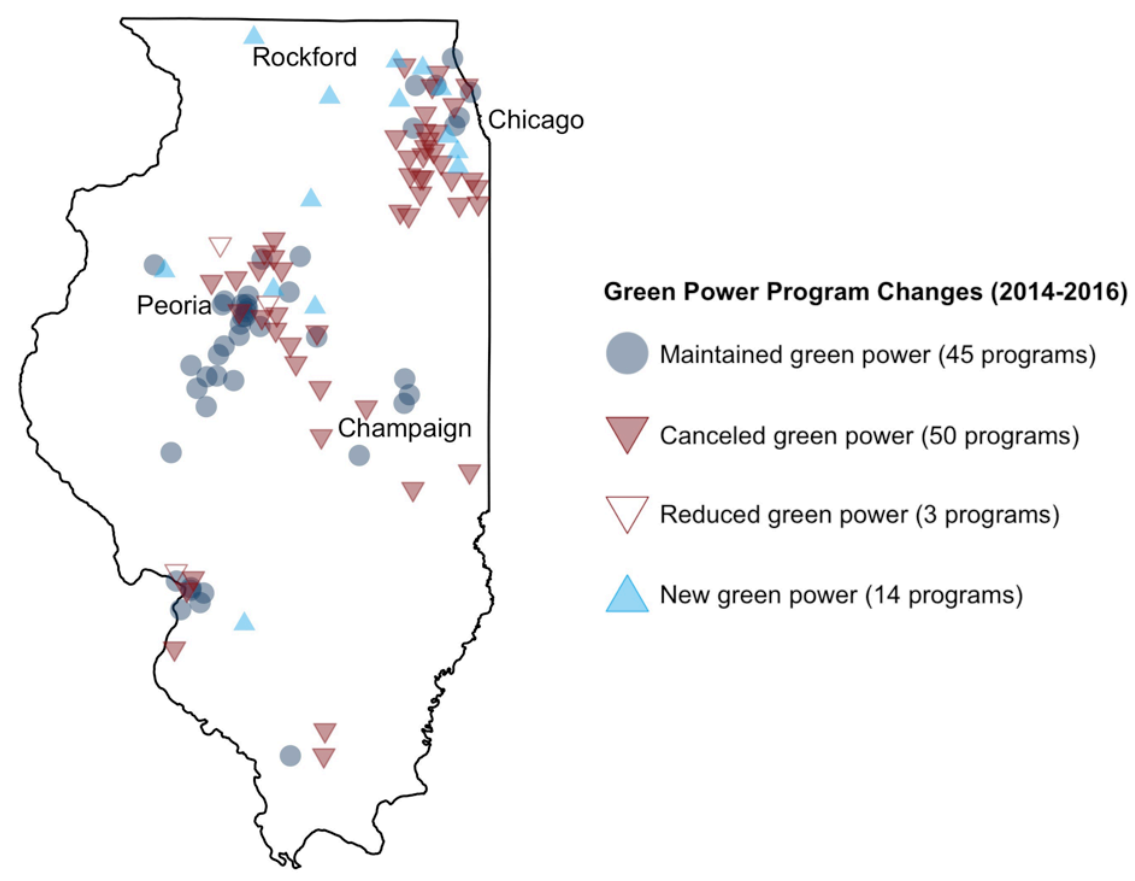

Figure 25. Changes to Illinois Green Power Programs from 2014 to 2016

The figure is based on data from Dynegy 2017 and ICC 2017.

\section{Massachusetts}

Customers in 37 Massachusetts cities and towns can procure green power through CCAs. Sixteen separate communities have aggregated, while the Cape Light Compact acts as a single aggregator on behalf of 21 towns in southeastern Massachusetts (Figure 26). The City of Lowell is the largest CCA in Massachusetts, procuring over 200,000 MWh of green power in 2016. 


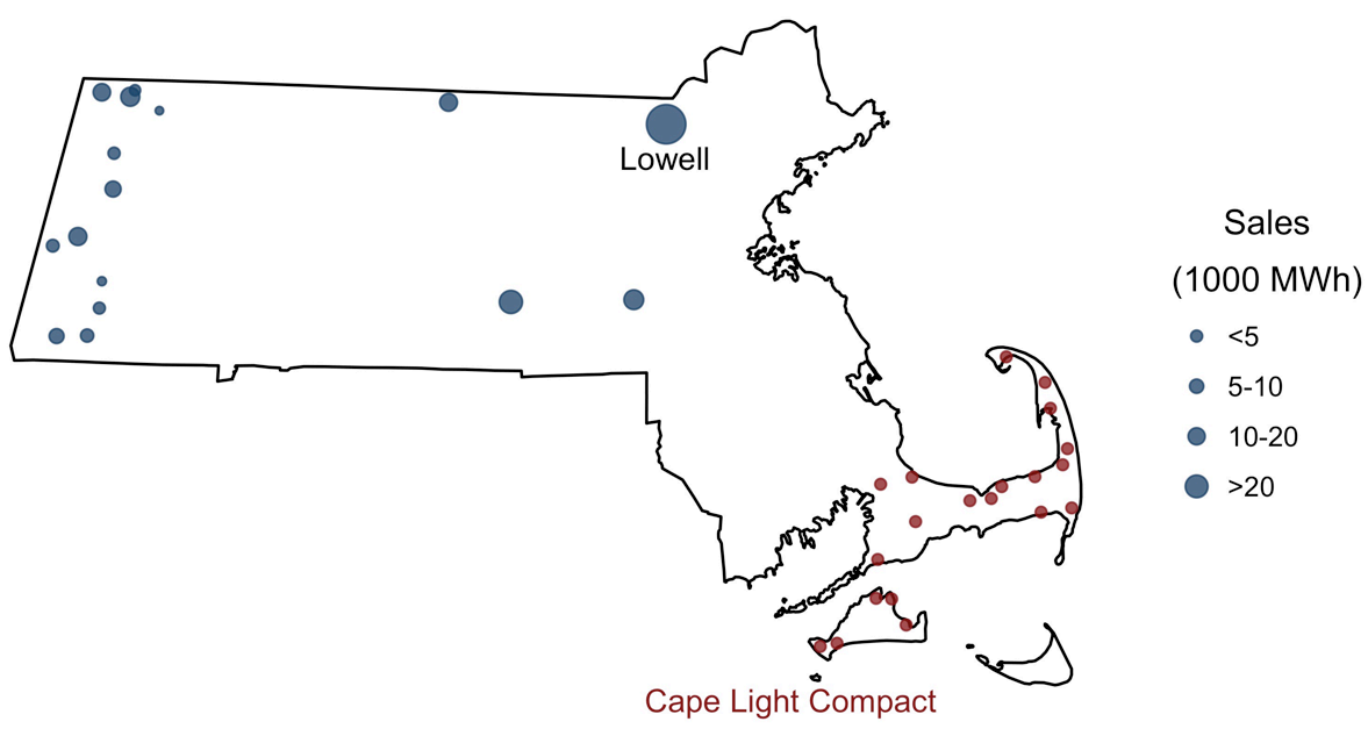

Figure 26. Massachusetts CCAs

CCA participation and sales in Massachusetts may increase going forward. In 2017, Arlington, Brookline, Gloucester, Somerville, Sudbury, and Winchester all launched new CCA programs that provide at least $5 \%$ more renewable energy than required by state law. ${ }^{10}$ These municipalities are members of the Metropolitan Area Planning Council, which is the regional planning agency for 101 cities and towns of metropolitan Boston. The council has selected Good Energy to help member municipalities procure their own energy resources (Un 2017). Other member municipalities, including Bedford, Hamilton, Stoneham, and Woburn are working with Good Energy to potentially launch their own programs (Mass Energy Consumers Alliance 2017).

However, similar to trends in Illinois, some municipal programs have stopped participating in green power CCAs. For instance, after launching in 2016, Melrose, Massachusetts returned customers to utility service in 2017 , when capacity charges in their load zone increased (Grover 2017). The city determined that utility rates would be more cost-effective, because National Grid had the ability to blend capacity charges across Massachusetts' three load zones in their rate structures. Melrose could provide a green power CCA option in the future, but this may depend on the potential net savings to customers. Similar to Illinois, this illustrates that the competitiveness of CCA rates is important for fostering green power CCA participation.

\footnotetext{
${ }^{10}$ See program details for each municipality: "Municipal Aggregation," Commonwealth of Massachusetts, http://www.mass.gov/eea/energy-utilities-clean-tech/electric-power/electric-market-info/approved-municipalaggregation-programs.html. Gloucester's program is not finalized, but it is expected to provide a default green option (Mass Energy Consumers Alliance 2017).
} 


\section{New York}

Westchester Power-New York's first and only CCA - serves over 100,000 customers across 20 municipalities. The $100 \%$ renewable option is $\$ 1-\$ 2 /$ month over the CCA's basic option. Fourteen of Westchester Power's municipalities have selected this option (Westchester Power 2017). Though the green option is more than the basic rate, it is still lower than average utility rates. Other New York municipalities are considering CCAs, including the Town of Oneonta, which voted to explore aggregation in 2016 (MEGA 2016; Richardson 2017). In 2016, the New York Public Service Commission published a decision in Case 14-M-0224 that was designed to make it easier for communities to form CCAs, and the full impacts of this decision are not yet known.

\section{Ohio}

Though over 200 communities work through the Northeast Ohio Public Energy Council (NOPEC 2017) to negotiate lower rates for electricity, only a few communities such as Cleveland and Cincinnati offer green power options. Participation has decreased over the past two years. One reason for this may be that both of Cleveland's green power options $(50 \%$ and $100 \%$ renewable) are at a price premium to their basic service (Constellation 2017). At the same time, green power sales have increased in the state. This may be a result of developments in Cincinnati's program. Cincinnati offers a 100\% renewable energy product supported by nationally sourced, unbundled RECs. Unlike Cleveland's program, the Cincinnati CCA provides a net savings to customers over utility rates (City of Cincinnati 2017). Other factors likely influence participation and sales from year-to-year, but rate savings volatility may influence this CCA market. 


\section{Power Purchase Agreements}

In a power purchase agreement (PPA), an electricity customer enters into a long-term contract with a generator to buy electricity. PPAs have been used, mostly by large non-residential customers to buy electricity from renewable energy projects located on the customers' premises (on-site projects) and remote from the customer (off-site). The analysis in this section is limited to off-site PPAs (Figure 27, below).

PPAs have two primary forms. In a physical PPA, the customer enters into a contract to buy electricity at a negotiated PPA rate. The purchased electricity is credited toward the customer's electric demand such that, from a billing perspective, the customer uses the electricity (regardless of whether the electricity is physically delivered to the customer's site). In a financial PPA, the customer enters into a contract for differences for electricity at a negotiated PPA rate. The generator sells electricity into the local grid at the local wholesale rate. The customer and generator are financially obligated to settle differences between the PPA rate and the wholesale rate; the customer pays the generator the difference when the wholesale rate is less than the PPA rate, and the generator pays the customer the difference when the wholesale rate is greater than the PPA rate. The generator's output is not credited toward the customer's electricity use. In a financial PPA, RECs are effectively unbundled from output and sold to the offtaker.

PPA sales and participation estimates in this report are based on data from BNEF (2017).

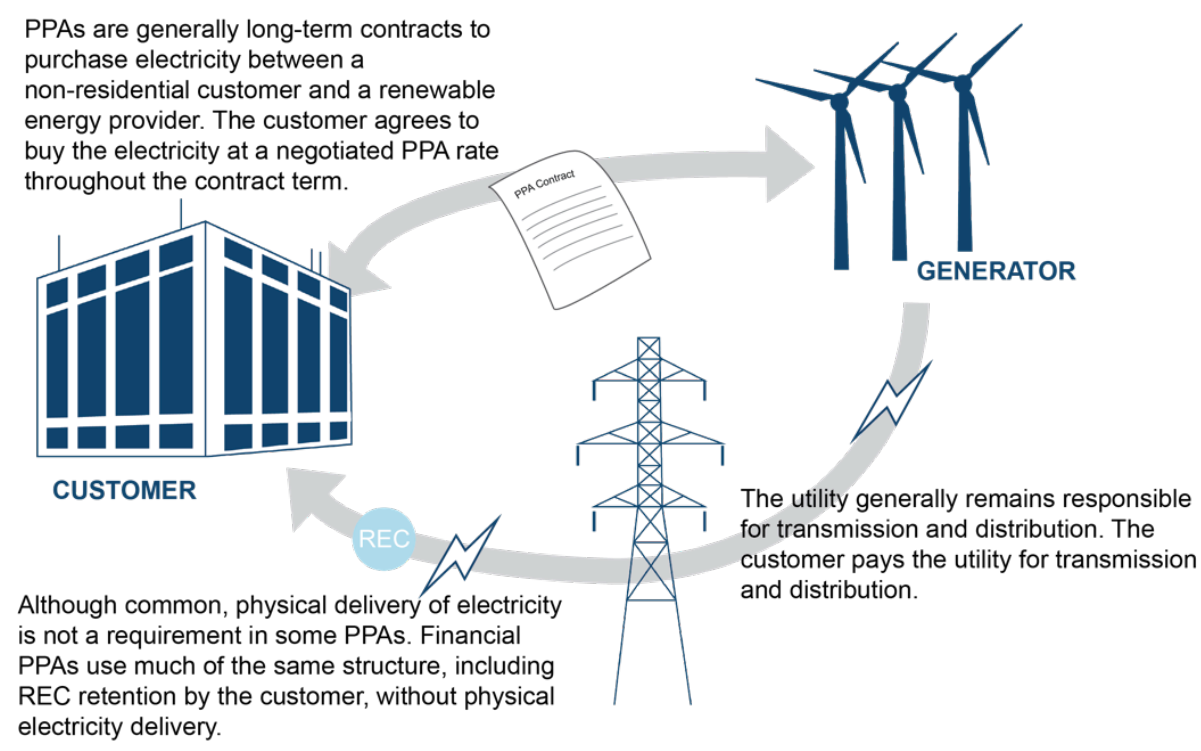

Figure 27. How power purchase agreements work

The figure provides a simplified schematic for visualization purposes. Specific contract structures may vary.

\subsection{Status of PPAs}

In 2016, 7.9 million MWh of green power were consumed through 210 PPAs; these results reflect projects commissioned by the end of 2016 where the customer purchases the RECs for voluntary purposes (Figure 28). Sales grew 19\% while the number of projects increased by $8 \%$, from 2015 to 2016. Sales in 2017 have not grown much from end of year 2016 because projects 
signed in 2017 have yet to come online. An additional 15.5 million MWh of PPAs were contracted for but not yet commissioned.

2016 PPA Sales:

7.9 million MWh

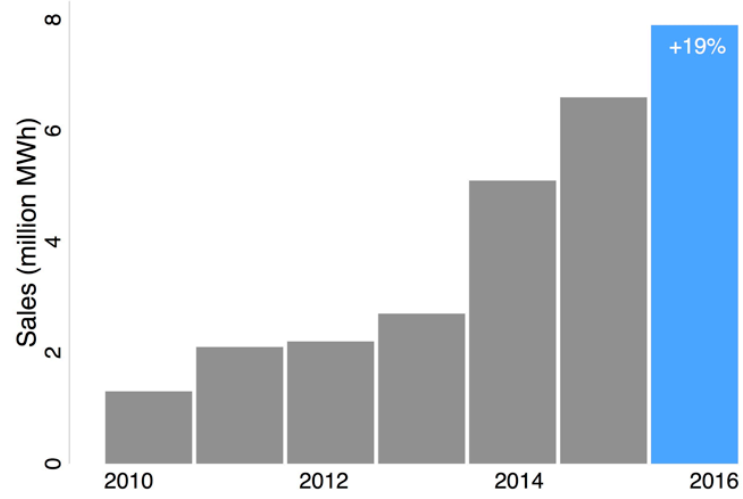

2016 PPA Projects:

210 projects

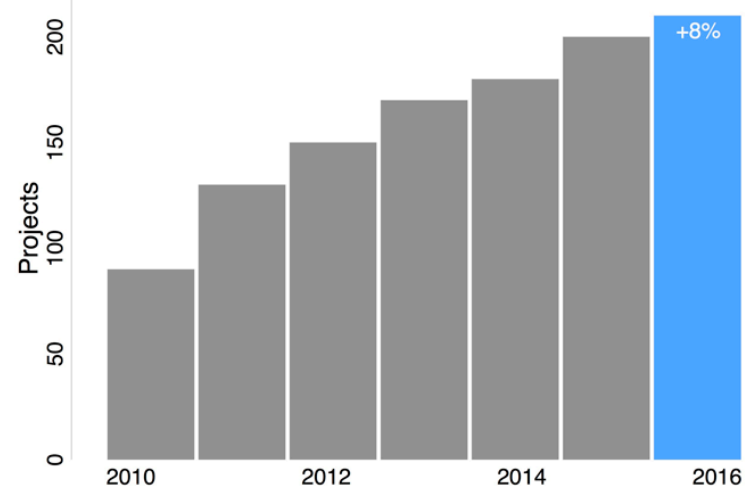

Figure 28. PPA sales and participation from 2010 to 2016

\subsection{Trends in PPAs}

Consistent with 2015, a large number of PPAs were signed in 2016, but the majority of projects signed in 2016 have yet to be commissioned (Figure 29). Signed capacity (with and without RECs passing to customers) peaked in 2015 at 3,684 MW. About 75\% (2,779 MW) of those projects have not yet been commissioned. Cumulatively, 10,214 MW have been signed, with 4,356 MW commissioned, as of July 2017.

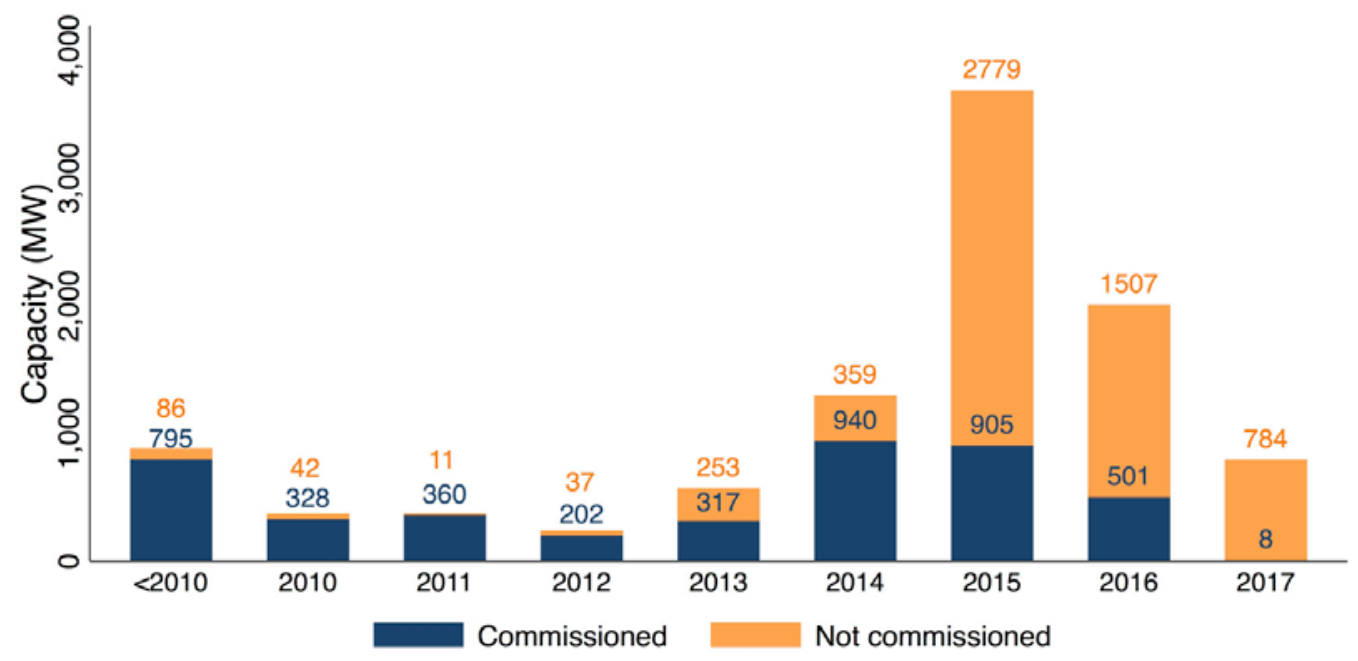

Figure 29. Project status of corporate PPAs, with and without RECs, through July 2017

In addition to growth trends, we summarize leading sectors and companies using PPAs, evidence of market expansion, and regional trends in PPAs. 


\section{Tech Sector Continues to Lead the PPA Segment}

In 2016, the tech sector continued to lead the PPA market, though contracts signed lagged behind 2015 (Figure 30). Purchasers in 2015 were likely increasing procurement in 2015, given uncertainty over federal tax incentives.

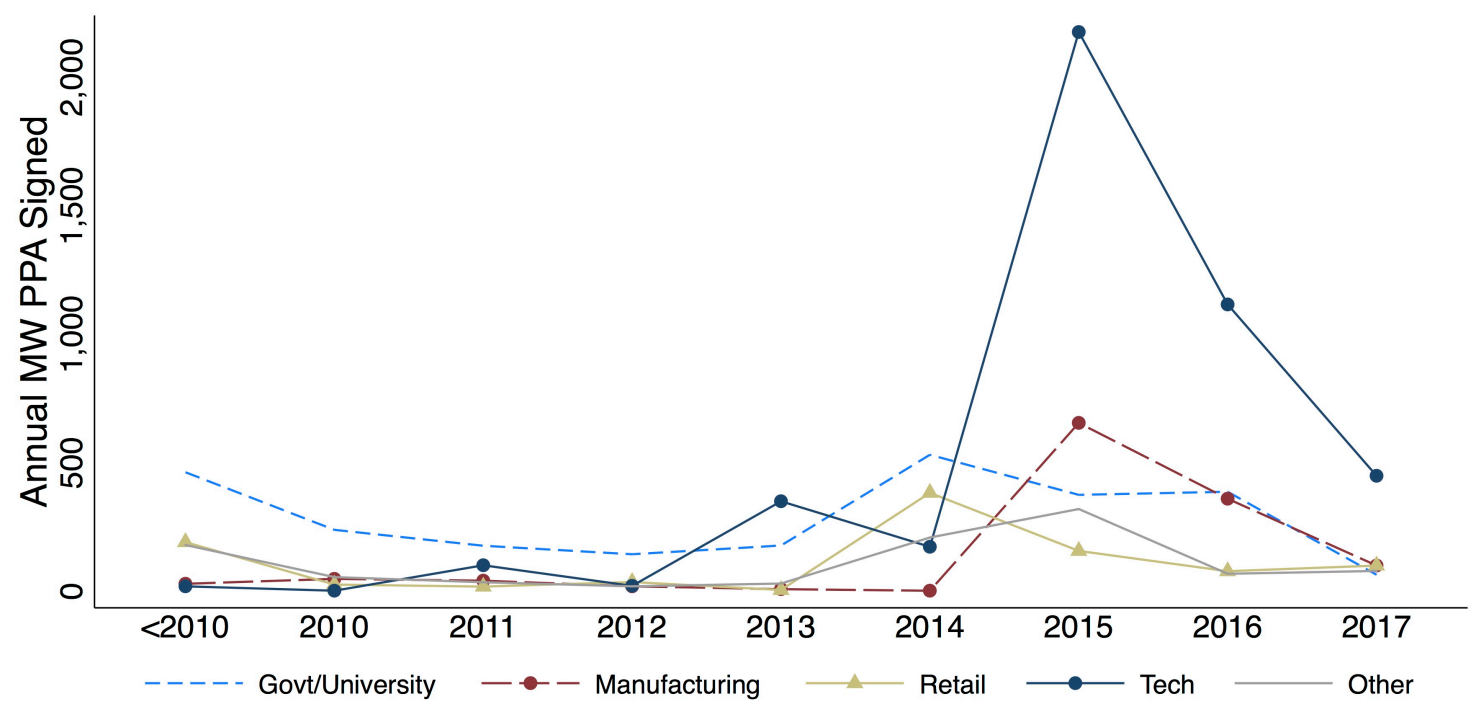

Figure 30. PPA capacity (MW) signed by sector by year, through July 2017

The largest five purchasers through July 2017 were Google (1,210 MW), Amazon (979 MW), U.S. Department of Defense (624 MW), Apple (439 MW) and Microsoft (433 MW). Non-tech companies, including government, retail, and manufacturing round out the rest of the top 15 PPA purchasers (Figure 31).

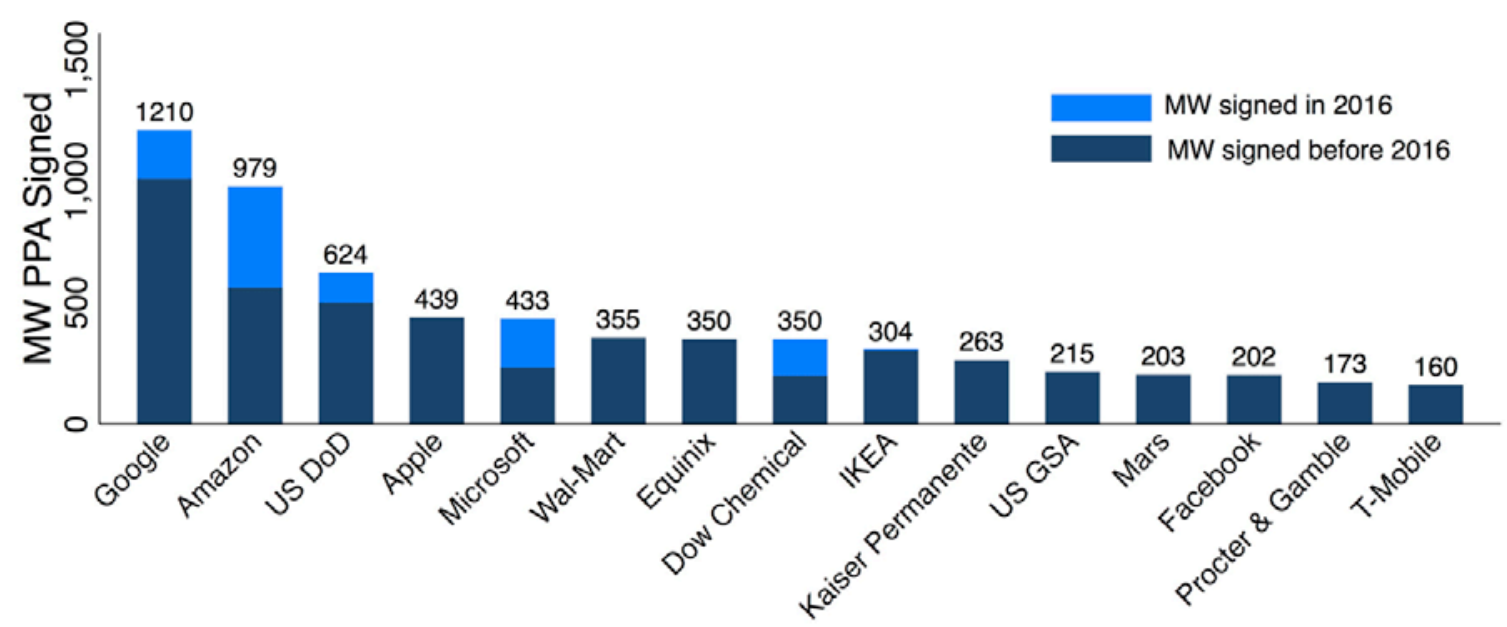

Figure 31. Leading institutions signing PPAs, through July 2017 
Focusing on 2016, other top purchasers included 3M (120 MW), Johnson \& Johnson (100 MW), and the University of California ( $80 \mathrm{MW}$ ). 2016 also saw the signing of an aggregate PPA for $60 \mathrm{MW}$ of solar by the Massachusetts Institute of Technology, the Boston Medical Center, and the Post Office Square Redevelopment Corporation. ${ }^{11}$ While large institutions continue to dominate the PPA market, the aggregate PPA signed by these institutions demonstrates that there is appetite from smaller institutions to achieve the benefits of signing a long-term PPA.

\section{New Companies are Continuing to Sign Off-Site PPAs}

The market for off-site PPAs continues to expand to new companies. ${ }^{12}$ In every year from 2010 to 2017, new companies have outnumbered companies that had previously signed PPAs (Figure 32). In 2016, 65\% of the companies that had signed PPAs were first-time PPA signers. This figure has been fairly consistent since 2012, ranging from $60 \%$ to $70 \%$ annually between 2012 and July 2017. This consistency indicates the market for PPAs is expanding (i.e., it is not simply the same companies signing new PPAs year after year).

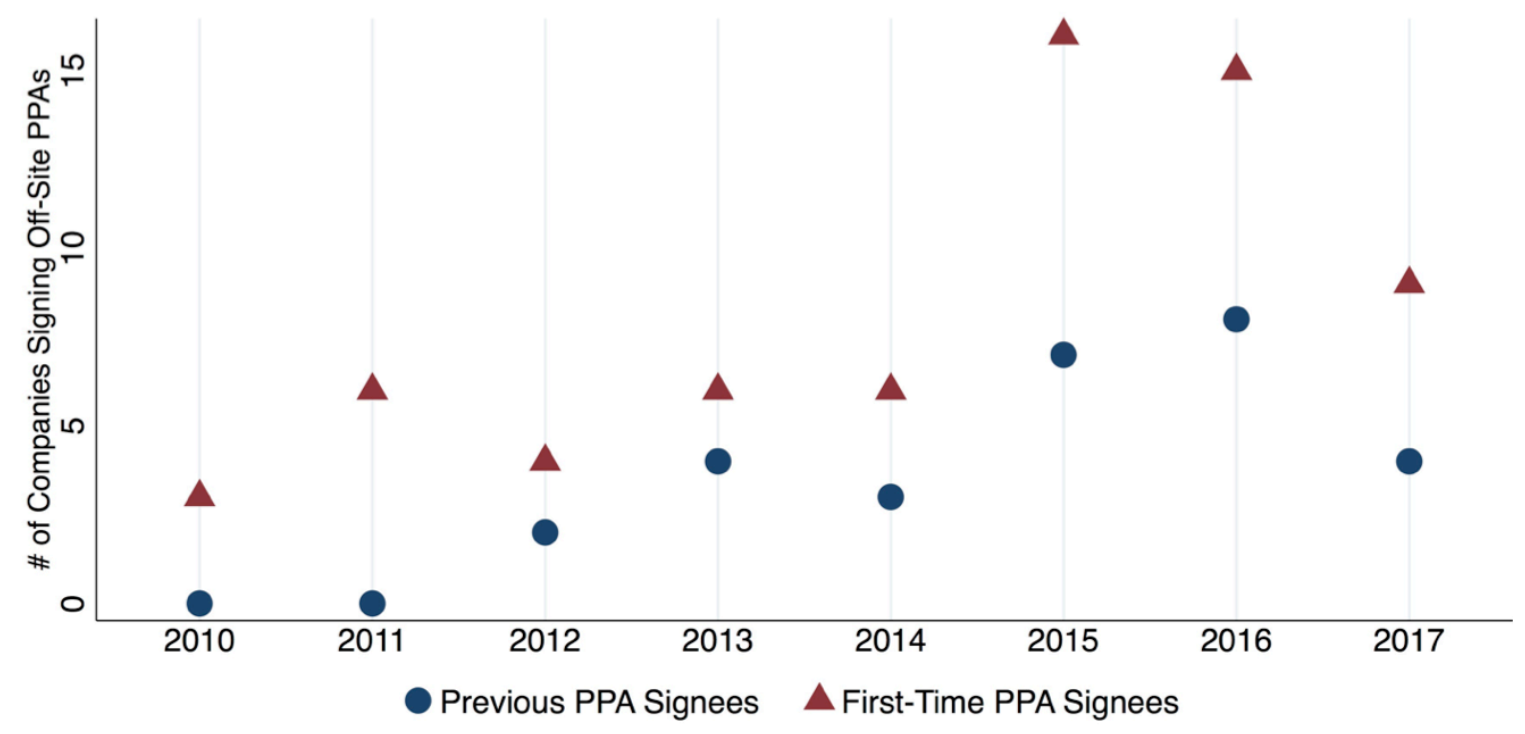

Figure 32. New companies signing off-site PPAs, through July 2017

\section{Most PPA Capacity is Located in Texas and the Southwest}

The Electric Reliability Council of Texas (ERCOT) and the Southwest Power Pool (SPP) dominated PPA capacity in 2016, as they have in recent years (Figure 33). In 2016, ERCOT accounted for $57 \%$ of signed PPA capacity, while SPP accounted for $29 \%$. PPAs in these regions have been for large-scale wind facilities. PJM has seen the third-largest capacity of PPAs in 2016, with a mix of large wind deals in Ohio and Pennsylvania, but also solar projects in Maryland, New Jersey, and Virginia.

${ }^{11}$ See Heeter, Cook, and Bird (2017) for details.

${ }^{12} \mathrm{We}$ focus on off-site PPAs here, as data on these purchases is more complete than it is for on-site PPAs. 


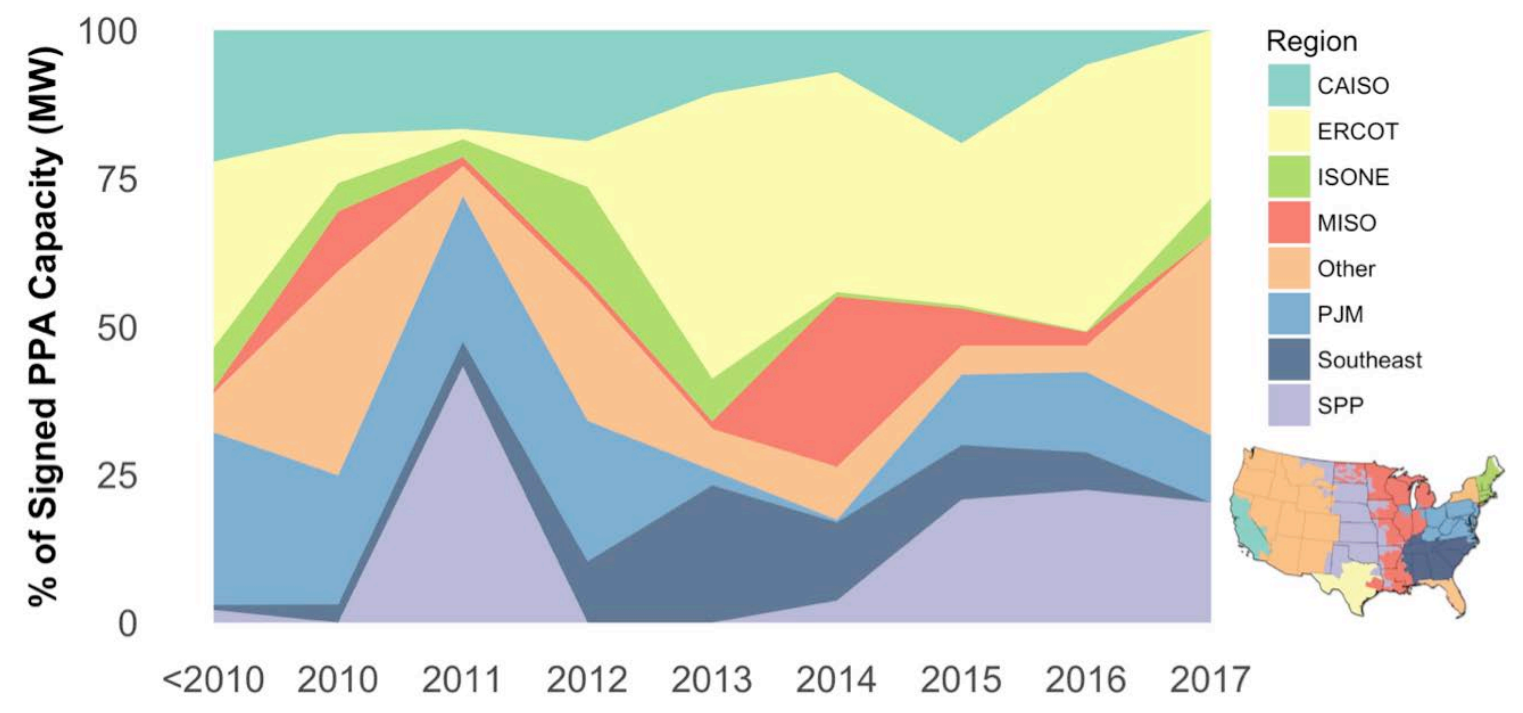

Figure 33. Share of signed PPAs by region (based on location of generator)

CAISO = California Independent System Operator ISONE = Independent System Operator of New England

MISO = Midwest Independent System Operator

PJM = Pennsylvania, Jersey, Maryland Power Pool

The lack of PPAs in some regions of the country is due both to a lack of a wholesale market for generators to sell into, which restricts the use of a financial PPA option, and to less favorable economics for renewable generators. Most of the western and southeastern states lack a wholesale market (Figure 34). In those regions, some green tariff options are emerging to address the needs of large commercial customers (Section 4).

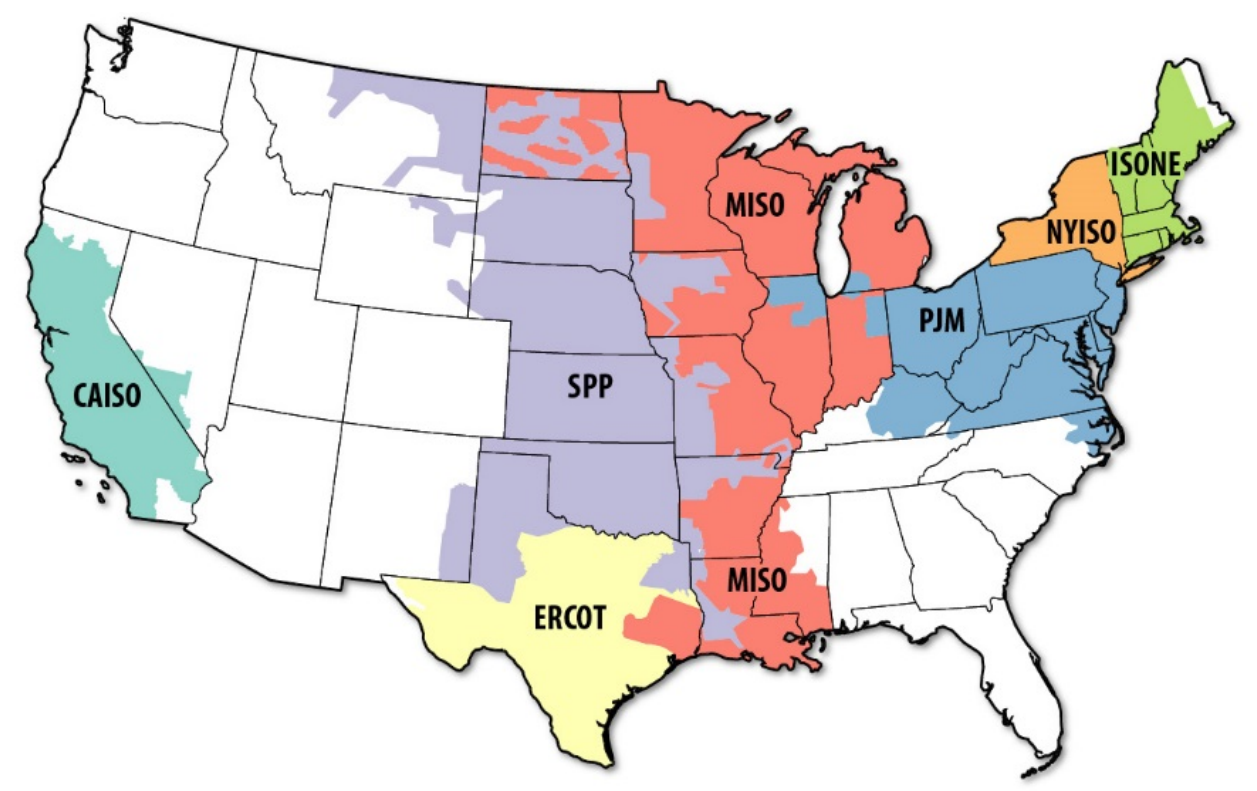

Figure 34. Map of regional transmission organizations and independent system operators Source: Billy Roberts, NREL 


\section{Community Solar}

In a community solar program, a utility or third-party project developer develops a solar project and sells the output to multiple subscribers (Figure 35). Community solar subscribers are generally compensated through utility bill credits that are proportional to the size of their subscription, though some programs are structured as a bill premium similar to a green pricing program.

To date, the vast majority of community solar customers have not received the RECs associated with their energy subscriptions. Community solar output is often used by utilities to meet RPS compliance obligations. For this reason, community solar sales outside of PG\&E's Solar Choice program have been excluded from our total estimates for the overall green power market because of double-counting concerns.

Community solar sales and participation data are based on an NREL data set of community solar projects compiled from various sources, including CEC (2017), IREC (2014), CERT (2017), and PG\&E (2017).

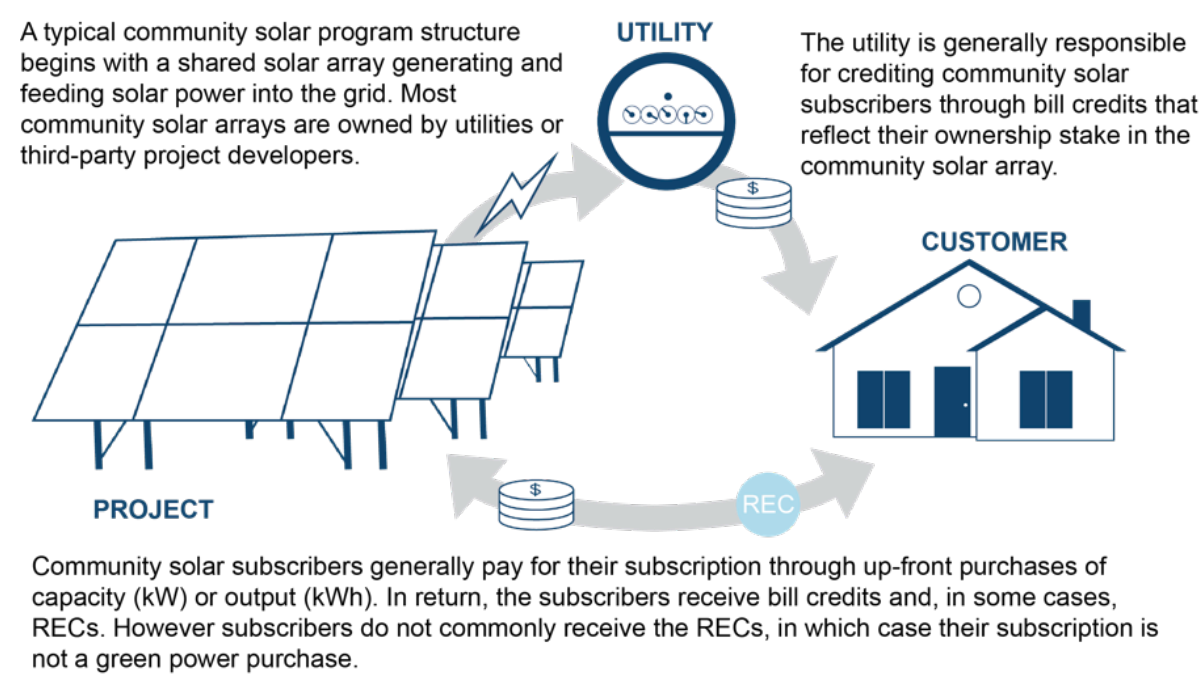

Figure 35. How community solar works

The figure provides a simplified schematic for visualization purposes. Specific program structures vary.

\subsection{Status of Community Solar}

In 2016, about 23,000 customers purchased 258,000 MWh of community solar output (Figure 36). Of these customers, at least 4,800 customers purchased about 32,000 MWh of green power through PG\&E's Solar Choice program, ${ }^{13}$ in which community solar subscribers retain RECs by program design (PG\&E 2017).

\footnotetext{
${ }^{13}$ PG\&E reported 14.6 MW of capacity had been subscribed through the project. Generation was estimated based on solar capacity factor for California, and the number of customers was estimated based on average electricity use per account in California.
} 
2016 Community Solar Sales:

258,000 MWh

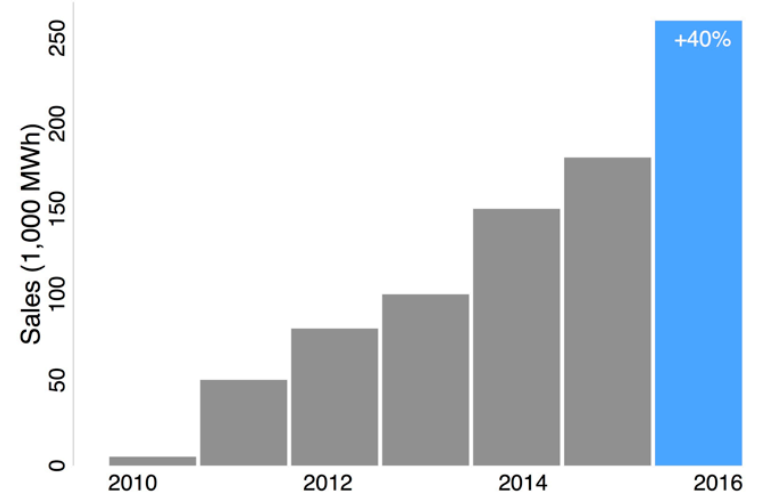

2016 Community Solar Participation: 23,000 customers

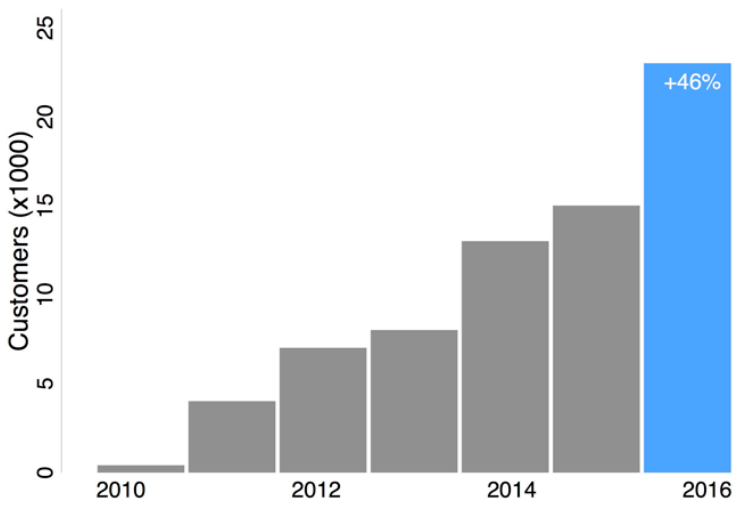

Figure 36. Community solar sales and participation from 2010 to 2016

\subsection{Trends in Community Solar}

As of September 2017, 223 community solar projects with a total of at least $278 \mathrm{MW}$ of capacity were operational in the United States. Community solar continues to show significant growth, adding about $37 \mathrm{MW}$ of capacity from 28 new projects in 2016. Nonetheless community solar has generally lagged early industry projections, in part because of regulatory uncertainty in Minnesota. We present three key trends from 2016: the geographic expansion of community solar continues, enabling legislation remains important to community solar growth, and Minnesota's and Wisconsin's community solar projects experience explosive growth.

\section{The Geographic Expansion of Community Solar and Enabling Legislation}

Fourteen states and Washington, D.C. have some form of legislation enabling community solar deployment (Figure 37). Enabling legislation can take many forms, including requirements for utilities to purchase community solar output (e.g., Colorado and Minnesota) and policies that explicitly allow virtual net metering (e.g., Massachusetts). About 77\% of community solar projects have been developed in a state that had enabling legislation. However, the majority of states with community solar projects do not have legislation that explicitly enables community solar, and more than $73 \mathrm{MW}$ of community solar have been deployed without the support of enabling legislation. Community solar deployment in these states is typically led by utilities. In addition, enabling legislation appears to have no effect on project size or whether a project sells out of subscriptions.

Although it is clear that enabling legislation is not a prerequisite for community solar, supportive policies may be foundational for large-scale community solar deployment. All states with more than 10 community solar projects have enabling legislation in place (Figure 37 ). 


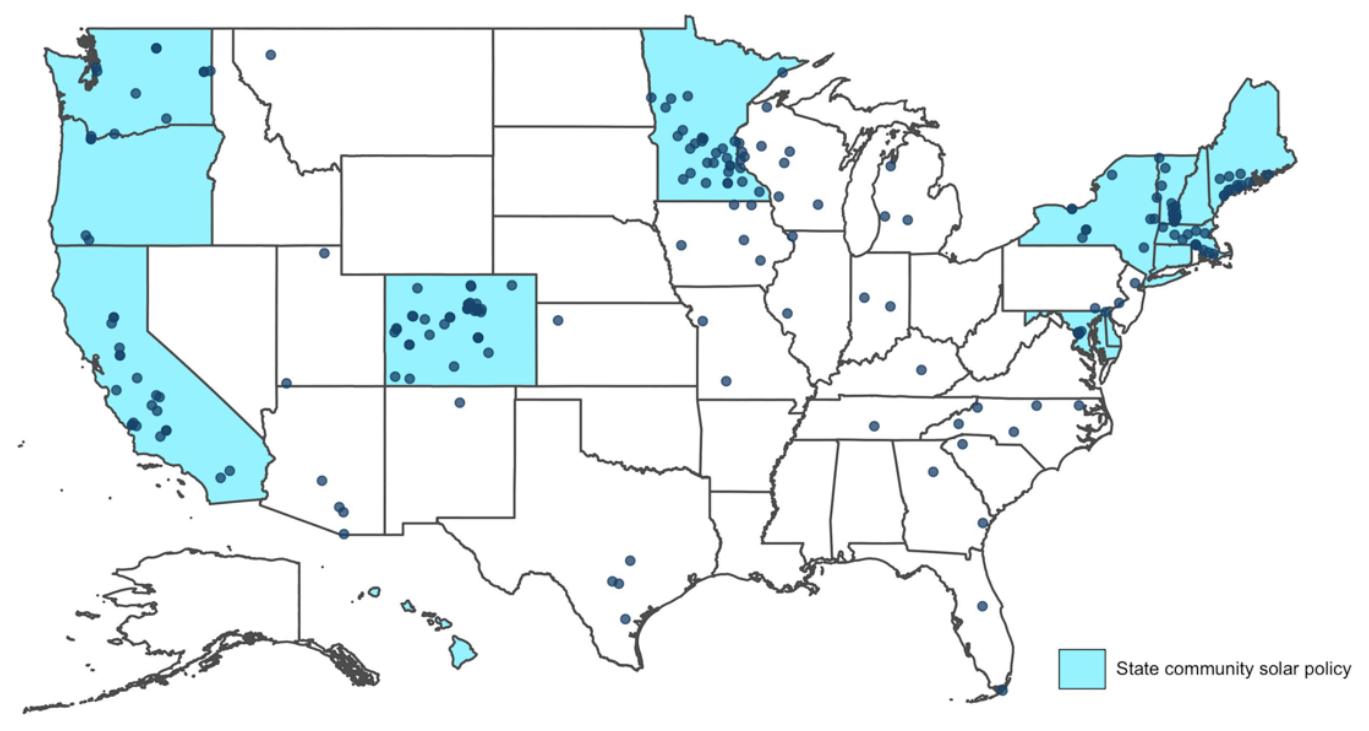

Figure 37. Active community solar projects and states with community solar policies

\section{Minnesota's and Wisconsin's Community Solar Boom}

In 2016 alone, Minnesota brought online 17 MW of community solar projects, led mostly by Xcel Energy. The launch of Xcel Energy's community solar program in 2014 and state legislation have allowed Minnesota to bring online $50 \mathrm{MW}$ of community solar to date. The program had a slow start because of interconnection issues. The implementation of a more standardized interconnection process addressed this issue and has allowed construction of these projects to proceed. Xcel has committed to a total of $96 \mathrm{MW}$ of community solar in and around the Minneapolis-Saint Paul metro area (Xcel Energy 2017). The majority of Xcel's community solar gardens have a completion date of late-2017 or 2018 (Figure 38).

Wisconsin has also shown community solar growth. As of September 2017, it has $2 \mathrm{MW}$ of operational community solar projects installed, despite the absence of enabling legislation. Wisconsin has an additional $6 \mathrm{MW}$ of community solar in the project queue that are pending approval or under construction. The state's public utilities and rural coops are the main drivers of the recent voluntary community solar push (Gulley 2017). Xcel Energy is responsible for two 1-MW projects in the state, one of which was experiencing permit delays but both of which are expected to be online in 2017 (Xcel Energy 2016). In 2015, Dairyland Power Cooperative issued a request for proposals for solar generation resources and in 2016 announced that agreements were in place for 15 new solar facilities in Wisconsin with $15 \mathrm{MW}$ of capacity (Dairyland Power Cooperative 2016). 


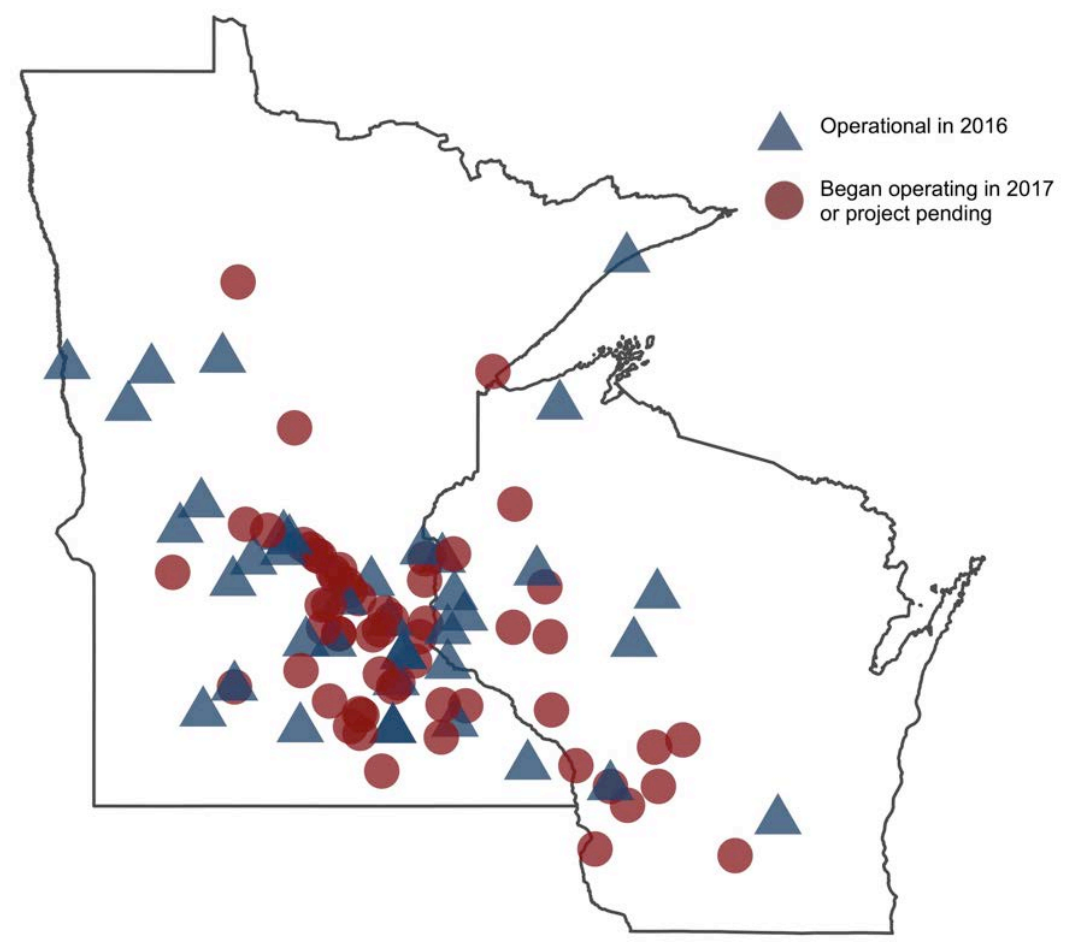

Figure 38. Active and pending community solar projects in Minnesota and Wisconsin 


\section{The Geography of Green Power}

In this section, we use available data to estimate the geography of green power demand and supply. Green power demand refers to the number of customers procuring green power within a state. Green power supply refers to the state of origin where the renewable energy is generated, regardless of where the green power is ultimately consumed. These state-level estimates are approximations based on the best available data and should be treated as such. The same data limitations that are discussed in Section 1 apply to the results presented in this section (Table 2).

The geography of green power is partially determined by the local availability of different green power mechanisms. Every electricity customer in the United States can buy green power through unbundled RECs and PPAs. ${ }^{14}$ However, the availability of the remaining green power mechanisms varies by region, state, and utility. Figure 39 depicts the primary green power mechanism by state in terms of number of customers. It illustrates how state and utility policy dictates the availability of green power options. Competitive suppliers meet the green power requirements of customers in restructured electricity markets in the northeast and Texas, while utility green pricing programs serve the needs of customers in fully regulated markets in most of the rest of the country. CCAs have emerged as the dominant green power option in five of the seven states that allow CCAs. Where local options are unavailable, customers primarily procure green power through unbundled RECs.

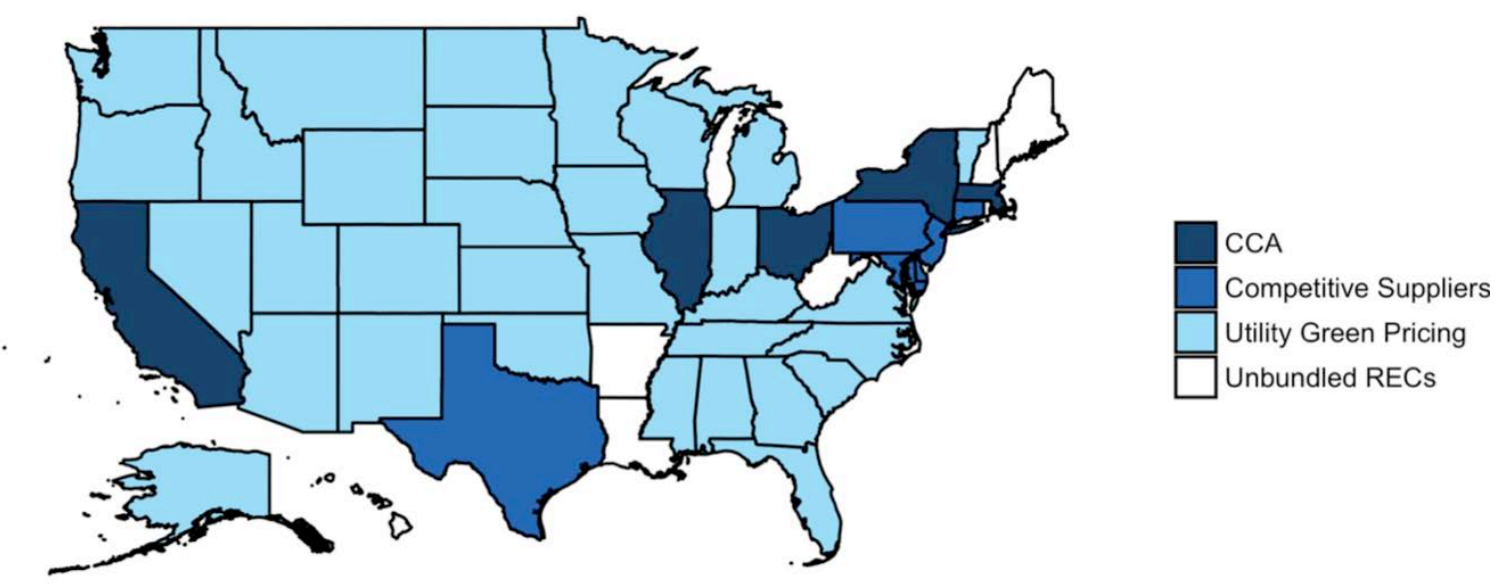

Figure 39. Primary form of green power demand (number of customers) by state

To illustrate how the local availability of green power products affects the geography of green power, Figure 40 depicts the number of green pricing program customers (left pane) and the state of origin (right pane) for green pricing programs by state (see the appendix for data tables). Led by Portland General Electric, Oregon is the state leader in terms of green pricing customers. Portland General Electric - and other Oregon programs - primarily source green power generation from within the region. As a result, generation for green pricing programs is concentrated in the Pacific Northwest and California, illustrating how green pricing programs tend to source local green power.

\footnotetext{
${ }^{14}$ Some states do not allow physical PPAs, though financial PPAs may be signed in any state.
} 
Green Pricing Customers (x1000)

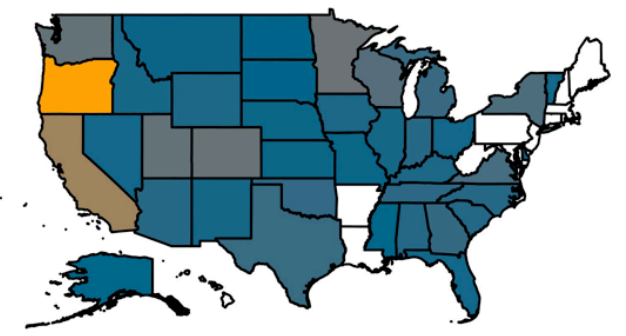

Green Pricing State of Origin (1000 MWh)

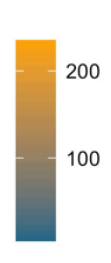

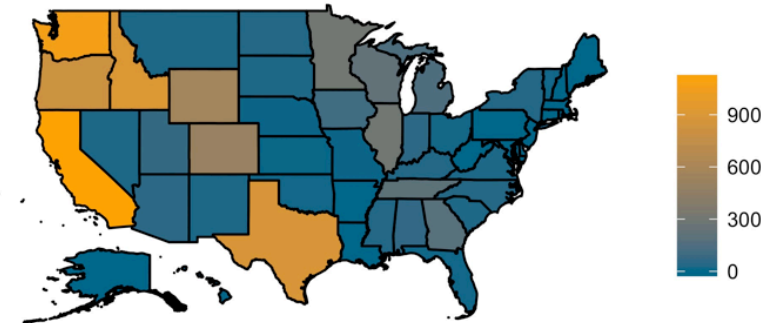

Figure 40. Utility green pricing program number of customers (left pane) and green power generation source (right pane) by state

States in white in left pane indicate no active green pricing programs in that state.

Differences between the left and right pane of Figure 40 illustrate how the location of green power customers does not necessarily overlap with the state of origin. For instance, Oregon has the largest number of green pricing program customers, but is the fifth largest state of origin for green pricing program generation.

Demand for unbundled RECs is more diffuse, given that unbundled RECs can be purchased anywhere in the country (Figure 41). Generation of unbundled RECs is similarly dispersed throughout the country, with more generation near customer bases such as California and the Northeast but also in resource-rich areas like the Midwest and Texas.

Unbundled REC Customers (x1000)

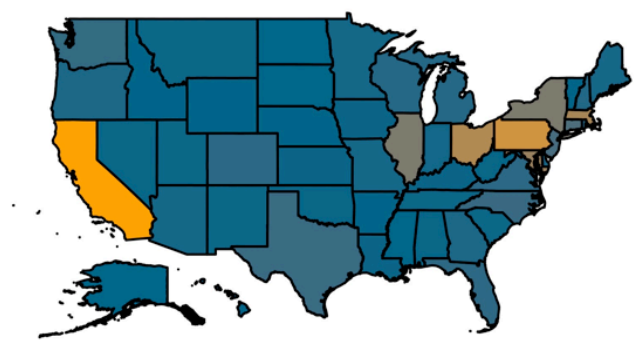

Unbundled REC State of Origin (million MWh)

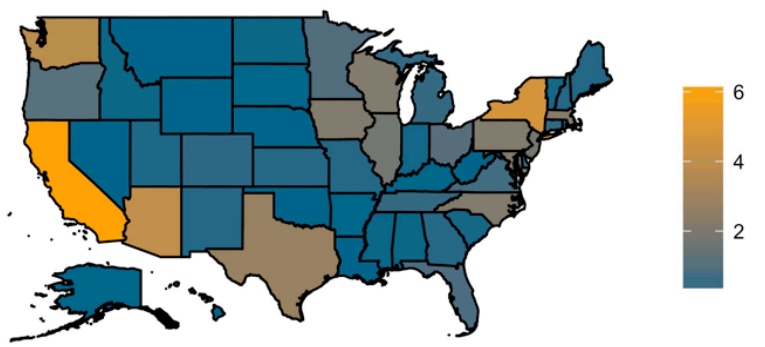

Figure 41. Unbundled RECs: Number of customers (left pane) and green power generation source (right pane) by state

To illustrate green power demand below the state level, Figure 42 illustrates zip code-level customer density based on data from the online energy services platform Arcadia Power. The data, a representative rather than comprehensive sample, show that the geography of green power demand generally corresponds with population centers, with higher demand in more densely populated metropolitan areas. At the same time, unbundled REC customers reside in all parts of the country, including rural areas. 


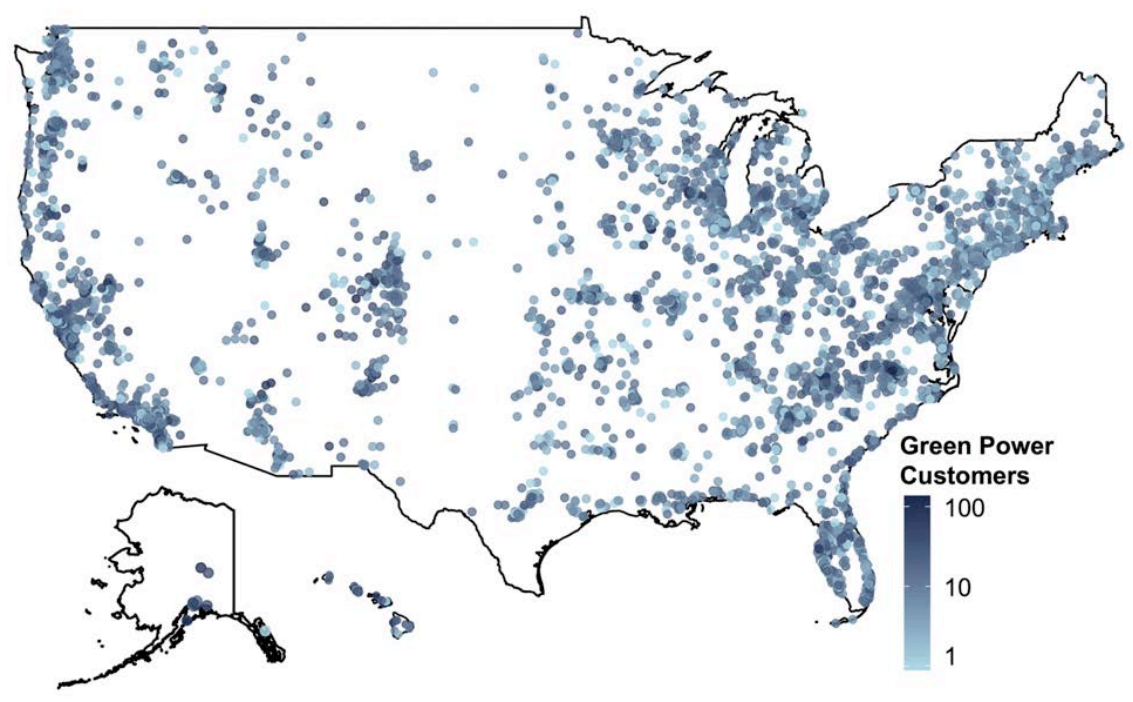

Figure 42. Geographic sample of residential and small commercial green power customers

Based on data from Arcadia 2017

Demand and generation for green power are more closely tied in PPAs than they are in other green power mechanisms (Figure 43). In physical PPAs, offtakers obtain green power from a resource located in their regional electric grid, often in the same state. Nonetheless, through financial PPAs, offtakers need not be located in the state of origin.

PPA Customers (Offtakers)

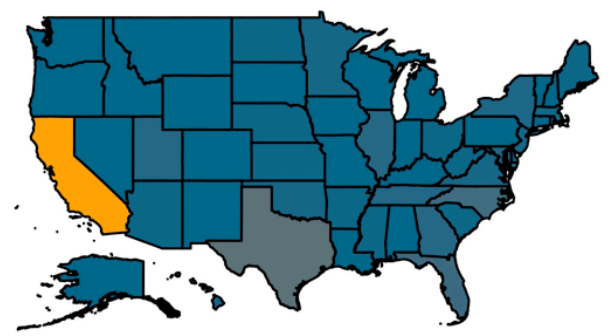

PPA State of Origin (Thousand MWh)

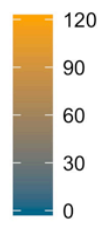

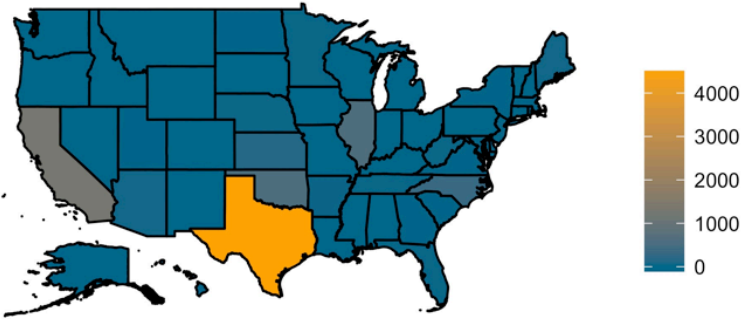

Figure 43. Number of PPAs (left pane) and generation (right pane) by state

Figure 44 depicts the geography of green power demand: the estimated sum of all green power customers from all green power mechanisms by state. The green power customer base is heavily concentrated in Illinois because of the large-scale participation of residential customers in CCAs in that state. Other states with large residential green power markets—such as Texas, Massachusetts, California, and New York - are among the other state leaders in terms of green power demand. 


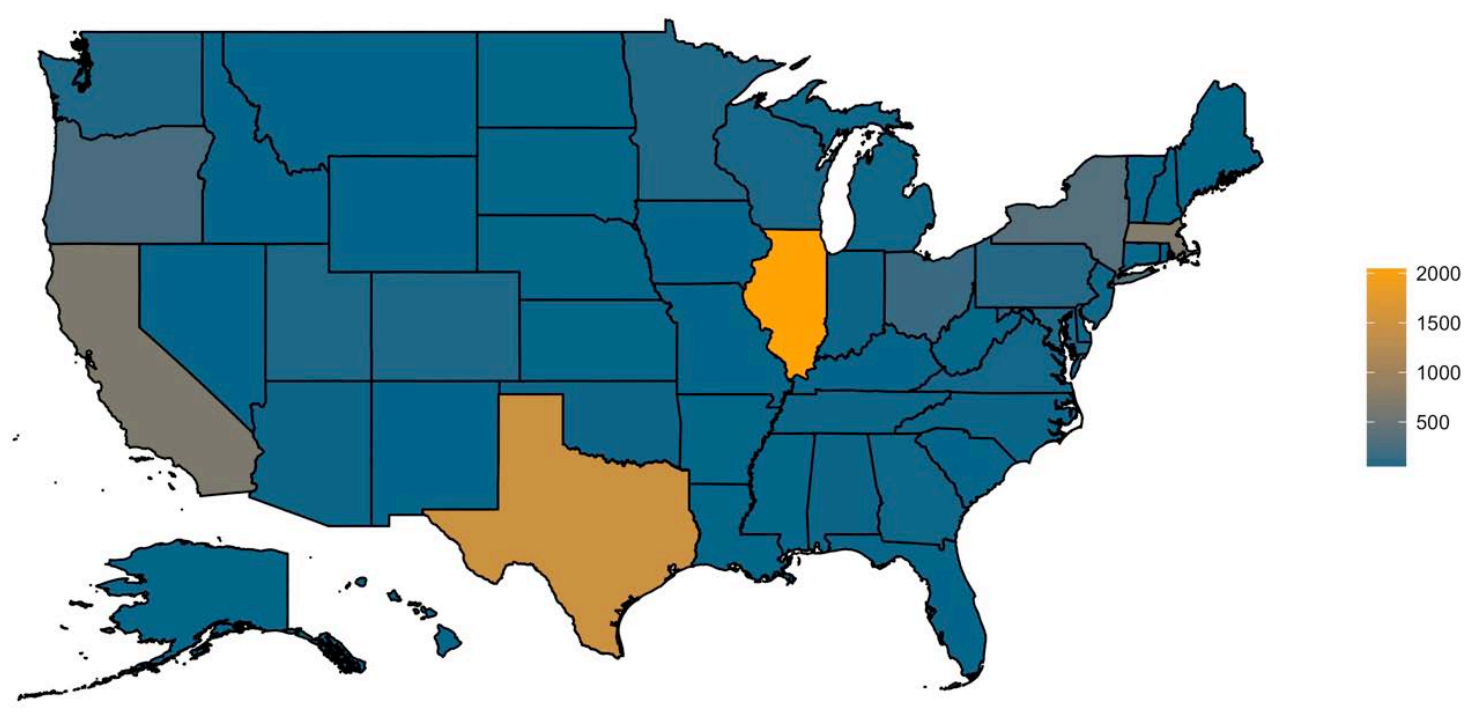

Figure 44. The geography of green power customer demand: Number of green power customers by state

Lastly, Figure 45 illustrates the geography of green power supply in terms of the MWh generated by state of origin. Texas, California, and Illinois - three states with strong wind resources - account for more than one third of the green power supply. Eighteen different states generated more than 1 million MWh of green power in 2016, and 42 states generated more than 100,000 MWh.

\section{Green Power State of Origin (million MWh)}

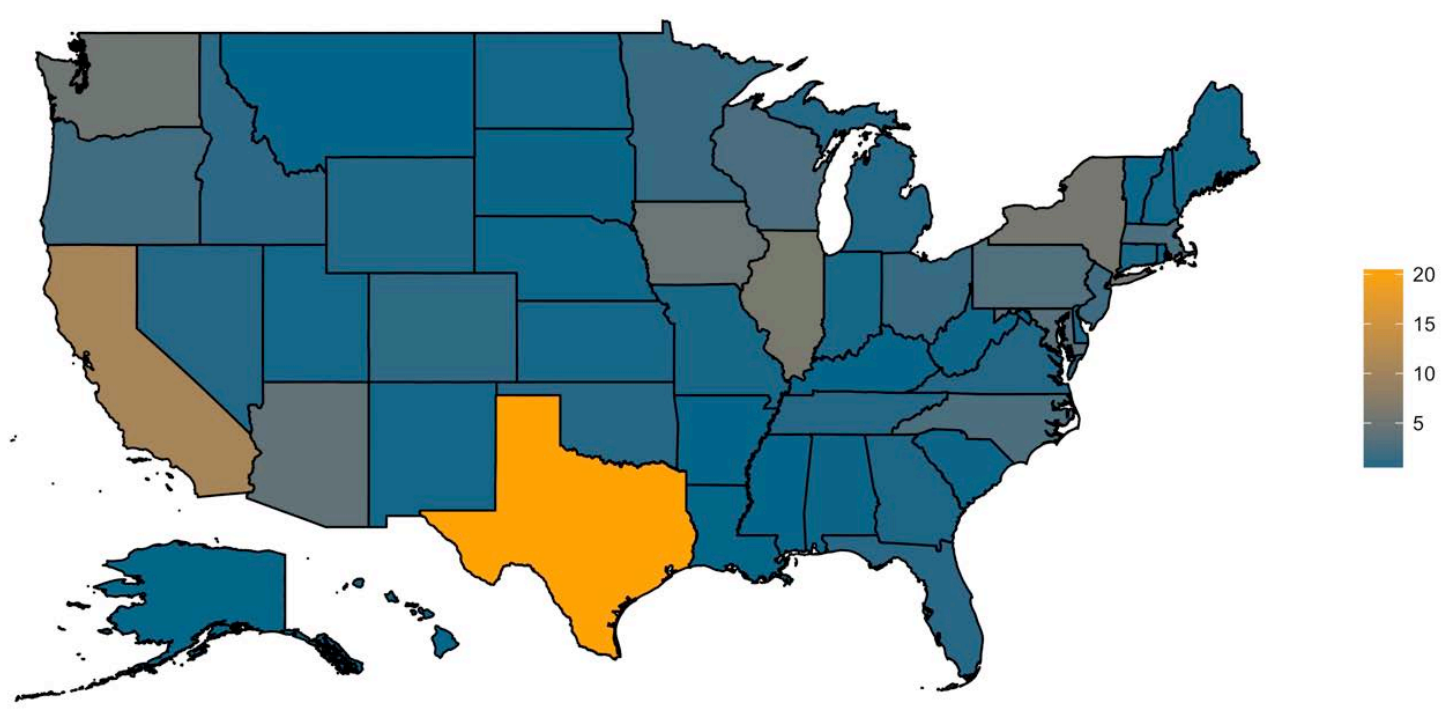

Figure 45. The geography of green power supply: Green power generation (million MWh) by state 


\section{Conclusions and Observations}

The U.S. voluntary green power market continues to grow. Green power sales increased by about 19\% from 80 million MWh in 2015 to 95 million MWh in 2016. Participation in green power markets increased by $45 \%$ from 4,305,000 customers in 2015 to 6,257,000 customers in 2016. This market expansion is primarily attributable to increasing green power sales in unbundled RECs, CCAs, and PPAs.

- Utility green pricing sales grew by about $6 \%$ from 2015 to 2016 . Consistent with previous years, this growth is primarily driven by the growth of a few large programs. However, the majority of green pricing programs showed declining sales from 2015 to 2016.

- Utility renewable contracts resulted in about 2.9 million MWh of green power generation in 2016 from 12 contracted projects. Utility renewable contracts are new green power mechanisms and several utilities are in the process of developing renewable contract programs.

- Competitive supplier trends are more difficult to assess because of data limitations. Based on available data, green power sales grew by $4 \%$ while participation grew by $34 \%$ increase in sales from 2015 to 2016.

- Unbundled REC sales grew by $22 \%$ and participation grew by $54 \%$ in 2016 , primarily through increasing corporate renewable energy procurement.

- CCA green power sales grew by about $18 \%$ from 2015 to 2016, primarily as a result of program expansions in California and Massachusetts, as well as the implementation of the first CCA in New York. At the same time, CCA green power sales continue to stagnate in Illinois and Ohio.

- PPA sales grew by $19 \%$ from 2015 to 2016 , with about $4,356 \mathrm{MW}$ of commissioned projects and an additional 5,858 MW of capacity in the project pipeline. The tech sector continues to lead the expansion of PPAs.

- Community solar sales increased by about $40 \%$ from 2015 to 2016 . However, green power sales, where customers retain the RECs, remain a small component of the community solar market.

A state-level geographic analysis of green power shows that green power demand is ubiquitous. Green power demand is higher in states such as Illinois, California, Texas, and Massachusetts where local green power options are available, but demand exists in every state and in both urban and rural areas. Demand for green power is likely to increase across the country as green power providers offer innovative new products and renewable energy prices continue to decline. Windrich states like Texas, California, and Illinois provide the majority of green power generation. 


\section{References}

Arcadia. 2017. Data obtained from Arcadia Power on 7/17/2017.

Bird, L., J. Heeter, E. O'Shaughnessy, B. Speer, C. Volpi, O. Cook, T. Jones, M. Taylor, P. Ralon, and E. Nilson. 2017. Policies for Enabling Corporate Sourcing of Renewable Energy Internationally: A 21st Century Power Partnership Report. Golden, CO: National Renewable Energy Laboratory. NREL/TP-6A50-68149. http://www.nrel.gov/docs/fy17osti/68149.pdf.

BNEF (Bloomberg New Energy Finance). 2017. US Corporate PPA Project Database.

Bonugli, C. 2017. U.S. Renewable Energy Map: A Guide for Corporate Buyers. Washington, D.C.: World Resources Institute.

CEC (Clean Energy Collective). 2017. “Community Solar Hub.” Accessed 9/12/2017. https://www.communitysolarhub.com/.

CERT (Clean Energy Resource Team). 2017. "Clean Energy Project Builder: Minnesota Community Solar.” Accessed 7/17/2017. http://www.cleanenergyprojectbuilder.org/ company/minnesota-community-solar.

City of Cincinnati. 2017. Frequently Asked Questions: Cincinnati Electric \& Natural Gas Aggregation Program. http://www.cincinnati-oh.gov/oes/residential-programs/aggregationprogram/frequently-asked-questions-cincinnati-electric-natural-gas-aggregation-program/.

Constellation. 2017. City of Cleveland Electric Aggregation Program. https://www.constellation.com/solutions/for-government/governmental-aggregation/ohioaggregation-programs/city-of-cleveland.html.

CPUC (California Public Utilities Commission). 2017a. Consumer and Retail Choice, the Role of the Utility, and an Evolving Regulatory Framework. Staff White Paper.

http://www.cpuc.ca.gov/uploadedFiles/CPUC_Public_Website/Content/News_Room/News and _Updates/Retail\%20Choice $\% 20$ White $\% 20$ Paper $\% 205 \% 208 \% 2017$.pdf.

CPUC. 2017b. CPUC and Energy Commission Joint En Banc on Changing Nature of Consumer and Retail Choice in California. http://www.cpuc.ca.gov/general.aspx?id=6442453394.

CPUC. 2017c. Community Choice Aggregation En Banc Background Paper. http://www.cpuc.ca.gov/uploadedFiles/CPUC_Public_Website/Content/About_Us/CCABackgro undPaperv2.pdf.

Dairyland Power Cooperative. 2016. "Dairyland Power Announces More Solar Projects." http://www.dairylandpower.com/dcontent/article/DPCannouncesadditionalsolarcontracts.pdf

Dynegy. 2017. "Illinois Communities We Serve." Accessed 7/17/2017.

https://www.dynegy.com/electric-supplier/municipal-aggregation/communities-we-serve/illinois. 
EIA (Energy Information Administration). 2017. "Electricity Data Browser.” Accessed 9/20/2017. https://www.eia.gov/electricity/data/browser/.

ERCOT (2017). Renewable Energy Credit Program Public Reports. https://www.texasrenewables.com/.

EPA (Environmental Protection Agency). 2017. EPA Green Power Partnership data. Received 6/5/2017.

Grover, M. 2017. "Melrose Community Electricity Aggregation Program Update.” Wicked Local. http://melrose.wickedlocal.com/news/20170628/melrose-community-electricityaggregation-program-update.

Gulley, T. 2017. "Rural Co-Ops and Public Utilities Have Voluntarily Built Nearly 100 MW of Community Solar. Here's Why." GreenTech Media.

Heeter, J., J.J. Cook, and L. Bird. 2017. Charting the Emergence of Corporate Procurement of Utility-Scale Solar. NREL/TP-6A20-69080. Golden, CO: National Renewable Energy Laboratory. http://www.nrel.gov/docs/fy17osti/69080.pdf.

ICC (Illinois Commerce Commission). 2017. Electric Switching Statistics. Accessed 5/2/2017, https://www.icc.illinois.gov/electricity/switchingstatistics.aspx.

IREC (Interstate Renewable Energy Council). 2014. "Shared Renewables Catalog."

Kaften, C. 2016. "Marin Clean Energy to Reduce Rates and Expand Service Area in September." Energy Manager Today. https://www.energymanagertoday.com/marin-clean-energy-to-reducerates-and-expand-service-area-in-september-0125248/.

Lancaster Choice Energy. 2017. "Residential Rate Details."

http://www.lancasterchoiceenergy.com/billing-rates/residential-rates/.

Lean Energy US. 2017. “CCA by State.” http://www.leanenergyus.org/.

LBNL (Lawrence Berkeley National Laboratory). 2017. "RPS Compliance Data." Received 9/20/2017.

Leschke, M. 2017. Preliminary Totals of Green-e Certified Sales. Center for Resource Solutions. Data received 9/15/2017.

Marex Spectron (2016). Environmental Markets data.

http://www.marexspectron.com/markets/environmental. Subscription-based service.

Mass Energy Consumers Alliance. 2017. "Green Municipal Aggregation.”

https://www.massenergy.org/renewable-energy/aggregation. 
MCE (Marin Clean Energy). 2017a. 2017 Integrated Resource Plan.

https://www.mcecleanenergy.org/wp-content/uploads/2017/07/MCE-2017-Integrated-ResourcePlan-Rev2017.04.07.pdf.

MCE. 2017b. "Local Sol 100\% Locally-produced Solar Energy."

https://www.mcecleanenergy.org/100-local-solar/.

MEGA (Municipal Electric \& Gas Alliance). 2016. "Town of Oneonta Unanimously Votes to Explore Community Choice Aggregation Program." http://www.megaenergy.org/town-oneontaunanimously-votes-explore-community-choice-aggregation-program/.

NOPEC (Northeast Ohio Public Energy Council). 2017. "What We Do." https://www.nopecinfo.org/about-nopec/what-we-do/.

NREL (National Renewable Energy Laboratory). 2017. Pathways for Off-Site Corporate PV Procurement. Golden, CO: National Renewable Energy Laboratory. NREL/FS-6A20-69081. https://www.nrel.gov/docs/fy17osti/69081.pdf.

O'Shaughnessy, C. Liu, and J. Heeter. 2016. Status and Trends in the U.S. Voluntary Green Power Market (2015 Data). Golden, CO: National Renewable Energy Laboratory. NREL/TP6A20-67147. https://www.nrel.gov/docs/fy17osti/67147.pdf.

PCE (Peninsula Clean Energy). 2017. “About.” https://www.peninsulacleanenergy.com/learnmore/about/.

PG\&E (Pacific Gas \& Electric). 2017. 2016 Annual Green Tariff Shared Renewables Program Report of Pacific Gas and Electric Company.

PG\&E and MCE. 2017. PG\&E-MCE Joint Rate Comparisons.

https://www.mcecleanenergy.org/wpcontent/uploads/2017/03/PGE_MCE_RateComparison_01012017.pdf.

RE100. 2017. “Companies.” Accessed 6/7/2017. http://there100.org/companies.

Richardson, D. 2017. “Town of Oneonta tackles Energy Initiatives.” The Daily Star. http://www.thedailystar.com/news/local_news/town-of-oneonta-tackles-energyinitiatives/article 82e6d95c-a2f0-5b9a-93ad-ca40173aa919.html.

San Francisco Water Power Sewer. 2017. "Residential Rates." http://sfwater.org/index.aspx?page=993.

Silicon Valley Clean Energy. 2017. "What Are My Energy Choices?" https://www.svcleanenergy.org/. 
Smith, B. 2016. "With our latest energy deal, Microsoft's Cheyenne datacenter will now be powered entirely by wind energy, keeping us on course to build a greener, more responsible cloud." https://blogs.microsoft.com/on-the-issues/2016/11/14/latest-energy-deal-microsoftscheyenne-datacenter-will-now-powered-entirely-wind-energy-keeping-us-course-build-greenerresponsible-cloud/.

SNL Energy (2017). REC Index. Data provided by Evolution Markets, Tradition Financial Services, Clear Energy Brokerage and Consulting, Karbone, and SREC Trade. Subscriptionbased service.

Tawney, L., J. Ryor, P. Barua, and B. Baker. 2017. Emerging Green Tariffs in U.S. Regulated Electricity Markets. Washington, D.C.: World Resources Institute.

Un, K. 2017. "MAPC Selects Good Energy as Green Municipal Aggregation Provider." https://www.mapc.org/news/mapc-selects-good-energy-as-green-municipal-aggregationprovider/.

Westchester Power. 2017. "Cleaner.” http://www.westchesterpower.org/cleaner/.

WRI. 2017. “Green Tariffs Map.” Accessed 9/20/2017. http://www.wri.org/green-tariffs-map.

WRI (World Resources Institute), and WWF (World Wildlife Fund). n.d. "Corporate Renewable Energy Buyers' Principles.” Accessed 9/20/2017. http://buyersprinciples.org/.

Xcel Energy. 2016. "Xcel Energy Breaks Ground on Solar*Connect Community Project." https://www.xcelenergy.com/company/media_room/news_releases/xcel_energy_breaks_ground on_solar*connect_community project.

Xcel Energy. 2017. "Solar Gardens Growing in Minnesota." https://www.xcelenergy.com/company/media_room/news_releases/solar_gardens_growing_in minnesota. 


\section{Appendix. State-by-State Data Tables}

This appendix provides state-level estimates of green power participation (Table A-1) and generation (Table A-2).

These state-level estimates are approximations based on the best available data and should be treated as such.

Table A-1. Green Power Customers by State

\begin{tabular}{|c|c|c|c|c|c|c|c|c|}
\hline State & Green Pricing & $\begin{array}{l}\text { Renewable } \\
\text { Contracts }\end{array}$ & $\begin{array}{l}\text { Competitive } \\
\text { Suppliers }\end{array}$ & $\begin{array}{l}\text { Unbundled } \\
\text { RECs }\end{array}$ & CCAs & PPAs & $\begin{array}{l}\text { Community } \\
\text { Solar }\end{array}$ & Total \\
\hline AK & 171 & 0 & 0 & 26 & 0 & 0 & 0 & 197 \\
\hline$A L$ & 7,787 & 0 & 0 & 98 & 0 & 0 & 0 & 7,885 \\
\hline AR & 0 & 0 & 0 & 94 & 0 & 1 & 0 & 95 \\
\hline$A Z$ & 9,827 & 0 & 0 & 347 & 0 & 1 & 0 & 10,175 \\
\hline $\mathrm{CA}$ & 111,186 & 0 & 1,212 & 21,267 & 527,696 & 120 & 4,800 & 666,280 \\
\hline $\mathrm{CO}$ & 53,600 & 0 & 0 & 992 & 0 & 0 & 0 & 54,592 \\
\hline CT & 0 & 0 & 4,842 & 2,974 & 0 & 0 & 0 & 7,816 \\
\hline DC & 0 & 0 & 12,192 & 2,402 & 0 & 0 & 0 & 14,594 \\
\hline $\mathrm{DE}$ & 339 & 0 & 3,571 & 323 & 0 & 0 & 0 & 4,233 \\
\hline $\mathrm{FL}$ & 2,929 & 0 & 0 & 1,127 & 0 & 10 & 0 & 4,066 \\
\hline GA & 16,040 & 0 & 0 & 522 & 0 & 5 & 0 & 16,567 \\
\hline $\mathrm{HI}$ & 0 & 0 & 0 & 65 & 0 & 2 & 0 & 67 \\
\hline IA & 5,282 & 2 & 0 & 169 & 0 & 0 & 0 & 5,453 \\
\hline ID & 4,214 & 0 & 0 & 88 & 0 & 0 & 0 & 4,302 \\
\hline IL & 3,533 & 0 & 150,715 & 6,685 & $1,909,997$ & 5 & 0 & $2,070,936$ \\
\hline IN & 10,622 & 0 & 0 & 257 & 0 & 0 & 0 & 10,879 \\
\hline KS & 1,416 & 0 & 0 & 162 & 0 & 1 & 0 & 1,579 \\
\hline KY & 5,599 & 0 & 0 & 167 & 0 & 0 & 0 & 5,766 \\
\hline LA & 0 & 0 & 0 & 149 & 0 & 0 & 0 & 149 \\
\hline
\end{tabular}




\begin{tabular}{|c|c|c|c|c|c|c|c|c|}
\hline State & Green Pricing & $\begin{array}{l}\text { Renewable } \\
\text { Contracts }\end{array}$ & $\begin{array}{l}\text { Competitive } \\
\text { Suppliers }\end{array}$ & $\begin{array}{l}\text { Unbundled } \\
\text { RECs }\end{array}$ & CCAs & PPAs & $\begin{array}{l}\text { Community } \\
\text { Solar }\end{array}$ & Total \\
\hline MA & 0 & 0 & 26,631 & 11,290 & 672,940 & 2 & 0 & 710,863 \\
\hline MD & 0 & 0 & 49,201 & 9,630 & 0 & 3 & 0 & 58,834 \\
\hline ME & 0 & 0 & 230 & 411 & 0 & 1 & 0 & 642 \\
\hline MI & 17,351 & 0 & 2 & 753 & 0 & 0 & 0 & 18,106 \\
\hline MN & 55,891 & 0 & 0 & 368 & 0 & 2 & 0 & 56,261 \\
\hline MO & 1,446 & 0 & 0 & 366 & 0 & 0 & 0 & 1,812 \\
\hline MS & 141 & 0 & 0 & 32 & 0 & 1 & 0 & 174 \\
\hline MT & 1,687 & 0 & 0 & 225 & 0 & 0 & 0 & 1,912 \\
\hline NC & 8,399 & 3 & 0 & 1,595 & 0 & 12 & 0 & 10,009 \\
\hline ND & 613 & 0 & 0 & 22 & 0 & 1 & 0 & 636 \\
\hline NE & 1,374 & 1 & 0 & 42 & 0 & 1 & 0 & 1,418 \\
\hline $\mathrm{NH}$ & 0 & 0 & 5 & 693 & 0 & 0 & 0 & 698 \\
\hline NJ & 0 & 0 & 16,930 & 2,454 & 0 & 2 & 0 & 19,386 \\
\hline NM & 3,473 & 0 & 0 & 203 & 0 & 0 & 0 & 3,676 \\
\hline NV & 3,372 & 2 & 0 & 140 & 0 & 0 & 0 & 3,514 \\
\hline NY & 31,849 & 0 & 186,697 & 6,647 & 106,473 & 3 & 0 & 331,669 \\
\hline $\mathrm{OH}$ & 2,931 & 0 & 17,621 & 12,299 & 119,128 & 1 & 0 & 151,979 \\
\hline OK & 13,822 & 1 & 0 & 107 & 0 & 2 & 0 & 13,932 \\
\hline OR & 233,872 & 0 & 0 & 517 & 0 & 0 & 0 & 234,389 \\
\hline PA & 0 & 0 & 62,873 & 15,898 & 0 & 0 & 0 & 78,771 \\
\hline RI & 0 & 0 & 2 & 436 & 0 & 0 & 0 & 438 \\
\hline SC & 7,106 & 0 & 0 & 192 & 0 & 1 & 0 & 7,299 \\
\hline SD & 434 & 0 & 0 & 29 & 0 & 0 & 0 & 463 \\
\hline $\mathrm{TN}$ & 10,887 & 0 & 0 & 205 & 0 & 4 & 0 & 11,096 \\
\hline
\end{tabular}




\begin{tabular}{|c|c|c|c|c|c|c|c|c|}
\hline State & Green Pricing & $\begin{array}{l}\text { Renewable } \\
\text { Contracts }\end{array}$ & $\begin{array}{l}\text { Competitive } \\
\text { Suppliers }\end{array}$ & $\begin{array}{l}\text { Unbundled } \\
\text { RECs }\end{array}$ & CCAs & PPAs & $\begin{array}{l}\text { Community } \\
\text { Solar }\end{array}$ & Total \\
\hline TX & 18,110 & 0 & $1,478,304$ & 1,742 & 0 & 22 & 0 & $1,498,178$ \\
\hline UT & 47,444 & 0 & 0 & 196 & 0 & 4 & 0 & 47,644 \\
\hline VA & 26,099 & 0 & 0 & 1,017 & 0 & 2 & 0 & 27,118 \\
\hline VT & 3,068 & 0 & 0 & 41 & 0 & 0 & 0 & 3,109 \\
\hline WA & 51,696 & 0 & 0 & 1,409 & 0 & 0 & 0 & 53,105 \\
\hline WI & 36,935 & 0 & 0 & 746 & 0 & 0 & 0 & 37,681 \\
\hline WV & 0 & 0 & 0 & 100 & 0 & 1 & 0 & 101 \\
\hline WY & 5,457 & 0 & 0 & 49 & 0 & 0 & 0 & 5,506 \\
\hline
\end{tabular}


Table A-2. Estimated Green Power Production (MWh) by State of Origin ${ }^{\mathrm{a}}$

\begin{tabular}{|c|c|c|c|c|c|c|c|c|}
\hline State & $\begin{array}{l}\text { Green } \\
\text { Pricing }\end{array}$ & $\begin{array}{l}\text { Renewable } \\
\text { Contracts }\end{array}$ & $\begin{array}{l}\text { Competitive } \\
\text { Suppliers }\end{array}$ & $\begin{array}{l}\text { Unbundled } \\
\text { RECs }\end{array}$ & CCAs & PPAs & $\begin{array}{l}\text { Community } \\
\text { Solar }\end{array}$ & Total \\
\hline AK & 781 & 0 & 0 & 92 & 0 & 0 & 0 & 873 \\
\hline$A L$ & 64,751 & 0 & 0 & 31,718 & 0 & 0 & 0 & 96,469 \\
\hline $\mathrm{AR}$ & 0 & 0 & 0 & 3,360 & 0 & 27,200 & 0 & 30,560 \\
\hline$A Z$ & 55,869 & 0 & 0 & $4,089,326$ & 0 & 54,141 & 0 & $4,199,336$ \\
\hline CA & $1,124,843$ & 0 & 11,353 & $6,193,618$ & $1,950,645$ & $1,292,563$ & 32,000 & $10,605,022$ \\
\hline $\mathrm{CO}$ & 498,963 & 0 & 0 & 320,964 & 260,791 & 0 & 0 & $1,080,718$ \\
\hline $\mathrm{CT}$ & 0 & 0 & 38,707 & 363,385 & 0 & 0 & 0 & 402,092 \\
\hline $\mathrm{DC}$ & 0 & 0 & 399,284 & $3,771,132$ & 0 & 0 & 0 & $4,170,416$ \\
\hline DE & 4,716 & 0 & 81,909 & 329,453 & 0 & 0 & 0 & 416,078 \\
\hline $\mathrm{FL}$ & 13,350 & 0 & 0 & 772,966 & 0 & 22,245 & 0 & 808,561 \\
\hline GA & 191,689 & 0 & 0 & 244,232 & 0 & 8,162 & 0 & 444,083 \\
\hline $\mathrm{HI}$ & 0 & 0 & 0 & 3,819 & 0 & 5,335 & 0 & 9,154 \\
\hline IA & 107,108 & 1,921,306 & 46,480 & $2,020,696$ & 745,800 & 0 & 0 & $4,841,390$ \\
\hline ID & 903,483 & 0 & 0 & 47,200 & 25,744 & 0 & 0 & 976,427 \\
\hline IL & 295,100 & 0 & $1,503,816$ & 1,689,299 & $1,988,800$ & 621,068 & 0 & $6,098,082$ \\
\hline IN & 59,006 & 0 & 0 & 86,415 & 248,600 & 0 & 0 & 394,021 \\
\hline $\mathrm{KS}$ & 6,453 & 0 & 0 & 213,856 & 0 & 166,281 & 0 & 386,590 \\
\hline KY & 35,024 & 0 & 0 & 2,383 & 0 & 0 & 0 & 37,407 \\
\hline LA & 0 & 0 & 0 & 7,228 & 0 & 0 & 0 & 7,228 \\
\hline MA & 0 & 0 & 128,589 & $2,257,226$ & 193,567 & 10,044 & 0 & $2,589,426$ \\
\hline MD & 0 & 0 & 299,323 & $2,208,639$ & 845,240 & 10,929 & 0 & $3,364,131$ \\
\hline ME & 0 & 0 & 1,139 & 184,851 & 64,522 & 61,653 & 0 & 312,166 \\
\hline $\mathrm{Ml}$ & 150,432 & 0 & 43,334 & 412,489 & 0 & 0 & 0 & 606,255 \\
\hline
\end{tabular}




\begin{tabular}{|c|c|c|c|c|c|c|c|c|}
\hline State & $\begin{array}{l}\text { Green } \\
\text { Pricing }\end{array}$ & $\begin{array}{l}\text { Renewable } \\
\text { Contracts }\end{array}$ & $\begin{array}{l}\text { Competitive } \\
\text { Suppliers }\end{array}$ & $\begin{array}{l}\text { Unbundled } \\
\text { RECs }\end{array}$ & CCAs & PPAs & $\begin{array}{l}\text { Community } \\
\text { Solar }\end{array}$ & Total \\
\hline $\mathrm{MN}$ & 299,682 & 0 & 0 & 874,490 & 198,880 & 16,563 & 0 & $1,389,615$ \\
\hline $\mathrm{MO}$ & 6,593 & 0 & 0 & 194,956 & 198,880 & 0 & 0 & 400,429 \\
\hline MS & 34,084 & 0 & 0 & 31,201 & 0 & 0 & 0 & 65,285 \\
\hline MT & 27,749 & 0 & 0 & 9,621 & 0 & 0 & 0 & 37,370 \\
\hline $\mathrm{NC}$ & 41,012 & 128,124 & 0 & $2,121,908$ & 0 & 325,200 & 0 & $2,616,244$ \\
\hline ND & 33,337 & 0 & 0 & 52,202 & 198,880 & 5,662 & 0 & 290,081 \\
\hline $\mathrm{NE}$ & 6,622 & 127,865 & 0 & 12,590 & 0 & 35,741 & 0 & 182,818 \\
\hline $\mathrm{NH}$ & 0 & 0 & 3,324 & 225,784 & 51,618 & 0 & 0 & 280,726 \\
\hline $\mathrm{NJ}$ & 0 & 0 & 96,748 & 1,706,384 & 0 & 21,550 & 0 & $1,824,682$ \\
\hline NM & 26,915 & 0 & 0 & 204,456 & 0 & 0 & 0 & 231,371 \\
\hline NV & 26,443 & 573,666 & 0 & 16,359 & 0 & 0 & 0 & 616,468 \\
\hline NY & 34,899 & 0 & 678,709 & $4,759,739$ & 277,273 & 11,122 & 0 & $5,761,743$ \\
\hline $\mathrm{OH}$ & 16,532 & 0 & 142,686 & $1,011,735$ & 248,600 & 3,637 & 0 & $1,423,189$ \\
\hline OK & 15,051 & 179,131 & 0 & 6,576 & 0 & 575,404 & 0 & 776,162 \\
\hline OR & 810,352 & 0 & 0 & $1,060,159$ & 112,423 & 0 & 0 & $1,982,934$ \\
\hline PA & 0 & 0 & 407,769 & $2,112,312$ & 455,215 & 0 & 0 & $2,975,296$ \\
\hline RI & 0 & 0 & 31 & 62,627 & 51,618 & 0 & 0 & 114,276 \\
\hline $\mathrm{SC}$ & 32,392 & 0 & 0 & 97,220 & 0 & 4,601 & 0 & 134,213 \\
\hline SD & 32,531 & 0 & 0 & 2,253 & 49,720 & 0 & 0 & 84,504 \\
\hline $\mathrm{TN}$ & 205,692 & 0 & 0 & 431,459 & 0 & 25,974 & 0 & 663,125 \\
\hline TX & 892,304 & 0 & $12,040,844$ & $2,743,490$ & 167,230 & $4,527,170$ & 0 & $20,371,038$ \\
\hline UT & 74,829 & 0 & 0 & 141,827 & 0 & 11,044 & 0 & 227,700 \\
\hline VA & 28,629 & 0 & 0 & 635,559 & 0 & 4,380 & 0 & 668,568 \\
\hline VT & 12,948 & 0 & 0 & 94,997 & 30,110 & 0 & 0 & 138,055 \\
\hline
\end{tabular}




\begin{tabular}{|l|l|l|r|r|r|r|c|}
\hline State & $\begin{array}{l}\text { Green } \\
\text { Pricing }\end{array}$ & $\begin{array}{l}\text { Renewable } \\
\text { Contracts }\end{array}$ & $\begin{array}{l}\text { Competitive } \\
\text { Suppliers }\end{array}$ & $\begin{array}{l}\text { Unbundled } \\
\text { RECs }\end{array}$ & CCAs & PPAs & $\begin{array}{l}\text { Community } \\
\text { Solar }\end{array}$ \\
\hline WA & $1,059,358$ & 0 & 0 & $3,871,368$ & 224,846 & 0 & 0 \\
Total
\end{tabular}

